\title{
The interplay between human cytomegalovirus and endothelial cells
}

Citation for published version (APA):

Slobbe-van Drunen, M. E. P. (1998). The interplay between human cytomegalovirus and endothelial cells. [Doctoral Thesis, Maastricht University]. Universiteit Maastricht. https://doi.org/10.26481/dis.19981127ms

Document status and date:

Published: 01/01/1998

DOI:

10.26481/dis.19981127ms

Document Version:

Publisher's PDF, also known as Version of record

\section{Please check the document version of this publication:}

- A submitted manuscript is the version of the article upon submission and before peer-review. There can be important differences between the submitted version and the official published version of record.

People interested in the research are advised to contact the author for the final version of the publication, or visit the DOI to the publisher's website.

- The final author version and the galley proof are versions of the publication after peer review.

- The final published version features the final layout of the paper including the volume, issue and page numbers.

Link to publication

\footnotetext{
General rights rights.

- You may freely distribute the URL identifying the publication in the public portal. please follow below link for the End User Agreement:

www.umlib.nl/taverne-license

Take down policy

If you believe that this document breaches copyright please contact us at:

repository@maastrichtuniversity.nl

providing details and we will investigate your claim.
}

Copyright and moral rights for the publications made accessible in the public portal are retained by the authors and/or other copyright owners and it is a condition of accessing publications that users recognise and abide by the legal requirements associated with these

- Users may download and print one copy of any publication from the public portal for the purpose of private study or research.

- You may not further distribute the material or use it for any profit-making activity or commercial gain

If the publication is distributed under the terms of Article $25 \mathrm{fa}$ of the Dutch Copyright Act, indicated by the "Taverne" license above, 
THE INTERPLAY BETWEEN HUMAN CYTOMEGALOVIRUS AND ENDOTHELIAL CELLS 
ISBN 90-9012048-3 


\title{
THE INTERPLAY BETWEEN HUMAN CYTOMEGALOVIRUS AND ENDOTHELIAL CELLS
}

\author{
PROEFSCHRIFT
}

ter verkrijging van de graad van doctor aan de Universiteit Maastricht,

op gezag van de Rector Magnificus, Prof. Dr. A.C. Nieuwenhuijzen Kruseman, volgens het besluit van het College van Decanen, in het openbaar te verdedigen op vrijdag 27 november 1998 om 14.00 uur door Marlea Elisabeth Philippa Slobbe - van Drunen geboren op 5 juli 1964 te Vught. 
Promotores: Prof. Dr. C.A. Bruggeman

Prof. Dr. M.C.E. van Dam - Mieras (Open Universiteit, Heerlen)

Co-promotor: Dr. R.C.R.M. Vossen (Maasland Ziekenhuis, Sittard)

Beoordelingscommissie:

Prof. Dr. M.J.A.P. Daemen (voorzitter)

Prof. Dr. M. Borgers

Dr. S. Michelson (Institut Pasteur, Paris)

Prof. Dr. J.J.H.H.M. de Pont (Katholieke Universiteit, Nijmegen)

Prof. Dr. R.F.A. Zwaal

The investigations described in this thesis were carried out at the Department of Medical Microbiology, University of Maastricht, Maastricht, The Netherlands.

Publication of this thesis was financially supported by the Dr. Ir. J.H. Van der Laar Stichting. 


\section{CONTENTS}

Chapter 1 General introduction

Chapter 2 Membrane related effects in endothelial celis induced by human cytomegalovirus

Chapter 3 Endothelial responses to HCMV infection in the context of vascular pathology

Chapter 4 Activation of protein kinase $\mathrm{C}$ enhances the infection of endothelial cells by human cytomegalovirus

Chapter 5 Nuclear import as a barrier to infection of human

umbilical vein endothelial cells by human

cytomegalovirus strain AD169

Chapter 6 Entry of cytomegalovirus in human umbilical vein endothelial cells

Chapter $7 \quad$ Summary and general discussion

Chapter 8 Samenvatting

List of Publications 


\section{GENERAL INTRODUCTION}




\section{INTRODUCTION}

\section{Herpesviruses.}

The family of herpesviruses is constituted of more than 80 different viruses. In humans eight different herpesviruses have been identified; herpes simplex virus type 1 (HSV-1), herpes simplex virus type 2 (HSV-2), varicella zoster virus (VZV). cytomegalovirus (CMV), Epstein-Barr virus (EBV), human herpes virus 6 (HHV-6), human herpes virus 7 (HHV-7) and human herpesvirus 8 (HHV-8) (Fields and Knipe, 1990; Moore and Chang, 1995). The herpesviruses have common characteristics; 1) the expression of viral genes is regulated by a particular cascade of events, 2) the viral DNA replication and capsid assembly take place in the nucleus of the host cell and 3) herpesviruses persist life-long in the host, usually in quiescent state, named latency.

The herpesvirus family can be divided into three sub-families, the $\alpha$-herpesviruses, the $\beta$-herpesviruses and the $\gamma$-herpesviruses (Malraux, 1992, Mcgeoch et al., 1995). HSV-1, HSV-2 and VZV belong to the $\alpha$-herpesviruses and CMV, HHV-6 and HHV-7 to the $\beta$-herpesviruses. The last sub-family, the $\gamma$-herpesviruses, consists of EBV and HHV-8.

\section{Characteristics of cytomegalovirus}

Cytomegalovirus infections are characterised by the enlargement of infected cells, called CYTOMEGALY (Goodpasture and Talbot, 1921), and the presence of intranuclear inclusion bodies. These inclusions were previously ascribed to parasitic or protozoan infections. In the beginning of this century, Cole and Kutner demonstrated that the disease was induced by a virus (Cole and Kutner, 1926). Cowdry and Scott were the first to describe the relationship between the inclusion bodies and cytomegalovirus infections (Cowdry and Scott, 1935). The isolation of human cytomegalovirus (HCMV) was first achieved in the fifties, in the same period that it became possible to culture human cells routinely (Smith, 1956, Weller et al., 1957, Rowe et al., 1956). Smith isolated HCMV from uterine cell cultures that were inoculated with salivary gland tissue (Smith strain). Furthermore, two other strains were isolated by Weller and co-workers from skin muscle cells (Davis strain) and from urine (Kerr strain). The strain most widely used in HCMV research (AD169 strain) was isolated from adenoidal tissue by Rowe.

Cytomegalovirus infects humans as well as a wide range of animal species, such as mice, guinea pigs, rats, bovine species and horses in a species specific manner 
(Staczek, 1990). The cytomegaloviruses are composed of 1) a core, which contains a linear-double stranded DNA molecule with a molecular weight of $150-155 \times 10^{6} \mathrm{Da}$, 2) an icosahedral symmetric capsid, composed of 162 capsomeres (Irmiere and Gibson, 1983), 3) a layer of protein (the matrix or tegument), and 4) an envelope with glycoproteins. The HCMV genome is extremely large - it consists of about 235 killo base-pairs, and contains approximately 200 open reading frames (Chee et al., 1990a). The genome has a high GC content $(57.2 \%)$ and can be divided into two segments: the unique long (UL) and unique short (US) regions. These regions are both flanked by an internal (IRI, IRs) and a terminal (TRI, TRs) base pair repeat sequence which permits isomerisation (Kilpatrick and Huang, 1977; DeMarchi et al., 1978).

\section{Infection and replication}

\section{A. Cell entrance (Fig. 1A).}

The infection process starts with the attachment of the virus at the cell surface. Heparan sulphate and viral glycoproteins like $\mathrm{gB}$ and $\mathrm{gH}$ are involved in the process of virus binding and penetration of the cells (Britt and Mach, 1996). HCMV enters fibroblasts via $\mathrm{pH}$-independent fusion (Compton et al., 1992). The following model is proposed by Compton for infection of fibroblasts: The first step is the attachment of HCMV to the cell surface heparan sulphate proteoglycans. This attachment is rapidly followed by a high affinity, heparan-resistant attachment in which gB and a 30-34 $\mathrm{kDa}$ cell surface receptor seem to be involved (Taylor and Cooper, 1990, Nowlin et all. 1991). These steps lead to changes in the viral envelope and/or changes in the cell membrane structure, which permit interaction of viral glycoproteins such as $\mathrm{gH}$ with additional cell membrane components such as a $92.5 \mathrm{kDa}$ cell surface protein (Keay and Baldwin, 1991; Keay and Baldwin, 1992; Keay et al, 1989). This eventually leads to the $\mathrm{pH}$-independent fusion of the virus envelope with the cell membrane and penetration of the capsid into the cytoplasm (Compton et al., 1992). Other host cell proteins that seem to be involved in the infection of HCMV are class 1 HLA molecules (Grundy et al., 1987), CD13 (Soderberg et al., 1993) and the cellular protein annexin II (Compton, 1995, Wright et al., 1994).

The mechanism of viral entrance into the cell doesn't seem to be identical in all cell types. In contrast to fibroblasts, endothelial and astrocytoma ceils appear to be entered by cytomegalovirus via endocytosis, and not by fusion with the cytoplasmic membrane (Chapter 6 , this thesis). 


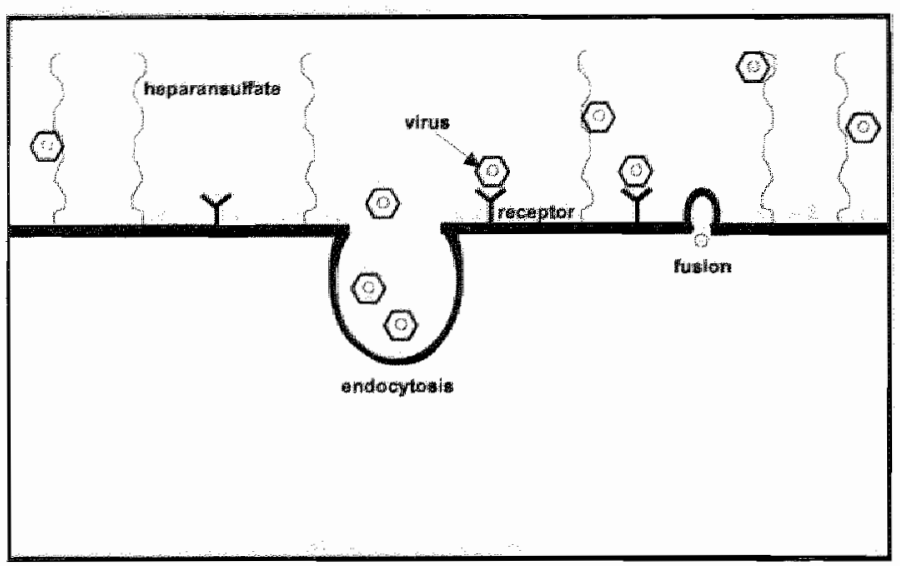

A

Ceill membrane

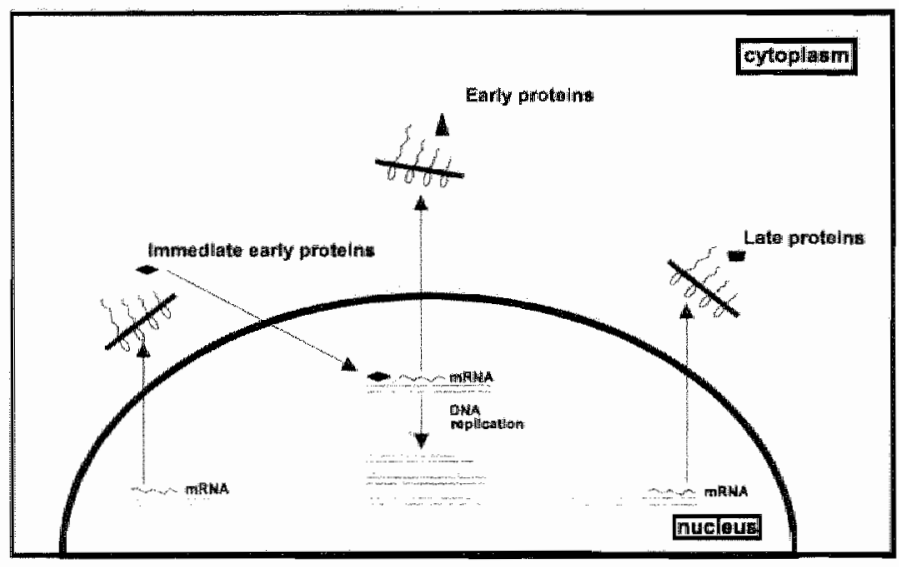

B

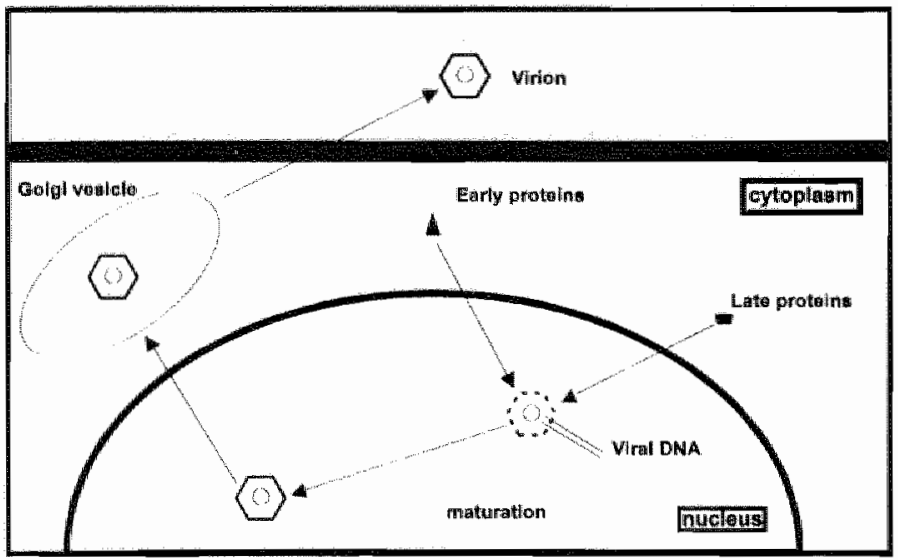

C

Fig.1 Infection and replication of cytomegalovirus.

A Cell entrance, B Transcription and replication, and C Virus assembly (see further text). 


\section{B. Transcription \& repication (Fig. 1B)}

After internalisation the virus must be uncoated and the DNA must be transported to the nucleus. The mechanism of uncoating and transport of the viral DNA is not yet understood. After entrance of the virall DNA in the nucleus viral transcription and replication processes take place. The expression of the CMV genome can be divided into three phases. The first phase is the immediate early phase (IE) followed by the early $(E)$ and finally by the late (L) phase (Wathen and Stinski, 1982). During each phase, a specific subset of HCMV genes is transcribed. The most active immediate early gene region is called the major immediate early region (UL 122123), which encodes several proteins such as the major $72 \mathrm{kDa}$ phosphorylated immediate early antigen (IE1) and a $80 \mathrm{kDa}$ polypeptide (IE2; Michelson-Fiske et $a_{i}$, 1977). The immediate early proteins are produced throughout the three phases of the viral replication. These proteins are non-structural viral proteins which have regulatory functions in viral gene transcription (Stenberg "1996). The transcription of the IE genes does not require the synthesis of viral proteins (Meier and Stinski, 1996). The expression of the early genes is dependent upon the IE gene products. About $75 \%$ of the viral genome is transcribed during the early phase of infection. During this period structural and non-structural proteins are produced and new viral DNA is synthesised (Anders and McCue, 1996). Finally, late genes are expressed after DNA replication. These genes encode mostly for structural viral antigens such as the viral capsid protein (UL86), tegument protein (UL83) and the envelope glycoproteins.

\section{Virus assembly (Fig. 1C)}

The CMV DNA is packaged in the nucleus into preformed capsids, which then acquire the tegument proteins and become enveloped (Severi et al., 1988, Gibson, 1993. Mocarski, 1996, Roizman, 1996, Gibson, 1996). The nucleocapsid contains four proteins (Chee et al., 1990a) ; the major capsid protein (153 kDa) encoded by UL86, constitutes approximately $90 \%$ of the capsid protein mass (Newcomb et al., 1993). The $34 \mathrm{kDa}$ minor capsid protein (UL85) (Irmiere and Gibson, 1985), the mCP-binding protein (UL46) and the smallest capsid protein (UL48/49, 8.5 kDa) (Gibson et al., 1996). Two other capsid forms are also encountered in HCMV infected cells: 1) the immature nuclear B-capsid, which does not contain viral DNA, contains a protein of approximately $36 \mathrm{kDa}$, the assembly protein (UL80), which is absent in the mature virions. 2) C-capsids, which are capsids that contain viral DNA and tegument but are not surrounded by an envelope. 
The tegument, or the viral matrix, is situated between the capsid and the envelope and contains about $40 \%$ of the CMV virion protein mass (Irmiere and Gibson, 1983). It has been assumed that the assembly of tegument proteins occurs at the nuclear membrane (Gibson, 1996). The HCMV tegument contains five predominant proteins: the high molecular- weight protein (UL48, $250 \mathrm{kDa}$ ), the HMWP-binding protein (UL47, $110 \mathrm{kDa}$ ) (Harmon and Gibson, 1996), the basic phosphoprotein (UL32, 150 kDa) (Jahn et al., 1987), the upper matrix protein (UL82, $71 \mathrm{kDa}$ ) (Ruger et al., 1987) and the lower matrix protein (UL83,65 kDa) (Somogyi et al., 1990). The basic phosphoprotein (Pp150 or BPP) is one of the most immunogenic proteins of CMV because of the post-translational modification by O-linked $\mathrm{N}$-glucosamine residues after the phosphorylation of the protein (Plachter et al., 1992).

The immature virion may use an envelopment / de-envelopment mechanism to cross the nuclear membrane, and presumably the final envelopment of the HCMV capsid occurs at the cytoplasmic membrane (Gibson, 1996). There is evidence that HCMV is transported in vesicles via the Golgi apparatus to the cell surface (Mocarski, 1993). The CMV envelope contains virion glycoproteins. The two most important glycoproteins are gB (UL55, $102 \mathrm{kDa}$ ) (Mach et al., 1986) and gH (UL75, $84 \mathrm{kDa}$ ) (Cranage et al., 1988). These two glycoproteins are involved in the virus entry. gB Is produced throughout the infection cycle and elicits humoral immunity (Pereira et al., 1982). The envelope also contains at least two proteins with multiple membranespanning domains: the integral membrane protein (UL100, $43 \mathrm{kDa}$ ) (Lehner et al., 1989) and the CMV G protein coupled receptor homologue (UL33 $44 \mathrm{kDa}$ ) (Chee et al., 1990b; Davis-Poynter et $a_{;} .$, 1997). The function of these proteins is not known in detail but may be related to escape mechanisms of the virus to elude the host's immune response.

\section{Epidemiology, pathology and clinical manifestations of HCMV}

HCMV transmission occurs person to person by direct or indirect contact (Alford and Britt, 1990). Primary infections are usually acquired during childhood from the mother by breastfeeding or after transmission from child to child in day care centres and schools (Stagno et al., 1980, Pass et al, 1986), and during early adulthood through sexual contact $(H o, 1990)$. The virus can be transmitted by urine, respiratory secretions, by blood "semen "breast milk and by faeces (Reynolds et al., 1973, Stagno et al., 1980). The virus is also transmitted by solid organ and bone marrow transplants (Hersman et al., 1982, Winston et al., 1988). The prevalence of primary and recurrent HCMV infections varies between different areas in the world and also between different age and socio-economic groups (Stagno et al., 1982). In the most 
developed countries the infection rate increases to about $80 \%$ in the elderly population.

Primary infection occurs when the host acquires CMIV for the first time and mounts an immune response. The outcome of these primary infections is dependent of the immune status of the host. In the immunocompetent host most CMV infections are asymptomatic and only occasionally a mononucleosis-like disease will develop (Sterner et al. 1970). In immunocompromised patients CMV infections can be life threatening. After a primary infection the virus persists in the host in a quiescent state (latency). The latent virus can reactivate later in life, triggered by immunosuppression, e.g. in AIDS patients and in transplant recipients receiving immunosuppressive therapy (Rubin, 1988, Ho, 1991b). In the latter group of patients CMV can cause fever, malaise, leukocytopenia, liver function disorders "impairment of graft functioning, pneumonia and colitis (Ho, 1991a, Jacobson and Mills, 1988, Gangan et al., 1994, Winston et al., 1987). In AIDS patients, on the other hand, $\mathrm{HCMV}$ more commonly causes retinitis, gastro-intestinal ulceration and haemorrhage. Besides the acute symptoms, which are associated with active HCMV infections, it has been assumed that HCMV is also involved in the development of chronic rejection after solid organ transplantation (Pouteil-Noble et al., 1993) and in the development of atherosclerosis (Melnick et al., 1995, Vercellotti, 1995).

CMV induced pathology can be caused either by a direct effect of the virus replication in the cells, which leads to cell damage and cell death. In addition, immunological factors play an important role in the CMV induced-pathology. Several cellular responses to CMV infection can cause indirect effects, such as for instance the production of cytokines and/or growth factors and the down regulation of the tumour suppressor gene p53 (Dubbing et al., 1989; Duncombe et al." 1990. Haagmans et al., 1994).

It has been shown in autopsy studies that virtually any organ can be infected by this virus (Toorkey and Carrigan, 1989). The cell types that can be infected by CMV are specialised parenchymal cells such as neurons, smooth muscle cells and hepatocytes, distributed cell types like epithelial cells, endothelial cells and fibroblasts and circulating cells like monocytes, macrophages and polymorphonuclear leukocytes (Sinzger et al. 1995; Sinzger et al. 1993a; Sinzger et al., 1993b). An interesting observation is the fact that in culture fibroblasts are more susceptible to CMV infection than epithelial cells, while in vivo cytomegalic cells are more associated with the epithelium than with fibroblasts. This difference perhaps can be explained by the fact that in vivo the epithelial layers of the respiratory tract, of the gastrointestinal tract, and of the genitourinary tract are the primary contact sites between the host organism and its environment, so they may 
be important sites were the virus can enter the host and were the virus is released via body excretions.

\section{Immune response}

Both cellular and the humoral immune responses seem to play a role in the control of CMV infection. The immune response to viruses is mainly achieved by the cellular immune response (Riddell and Greenberg, 1994, Reusser et al., 1991), in which the cytotoxic $T$ lymphocytes (CTLs) play a crucial role. Antiviral CTLs specifically recognise and lyse infected cells bearing specific viral and major histocompatibility complex (MHC) antigens. CD8 T cells have cytolytic activity and recognise viral antigens presented by MHC-l molecules. CD4 T cells have regulatory functions and recognise viral antigens presented by MHC-II molecules. The development of antiCMV CD8 cytotoxic cells seems to be dependent on anti-CMV CD4 T cells (Greenberg et al., 1991). The major products of CD4 T cells are cytokines like interleukin-2 (IL-2), interferon- $\gamma$ ( $\mathrm{FN}-\gamma$ ) and tumour necrosis factor (TNF). IL-2 is a growth factor for CD4 and CD8 T cells, it activates natural killer (NK) cells and promotes $\mathrm{B}$ cell proliferation. IFN-y and TNF inhibit virus replication (Riddell and Greenberg, 1995). The CMV antigens recognised by CMV-specific CTLs are products of the immediate early region of the CMV genome and antibodies against pp65 (Reddehase and Koszinowski, 1984; Davignon et al., 1995).

Natural killer (NK) cells target cells with little or no MHC class I molecules. During acute CMV infections, CMV infected cells are lysed by NK cells. The NK cells are an essential component of the acute response to vira infection (Miller and Sedmak, 1998). The down regulation of the expression of MHC class I molecules on the membrane of CMV infected cells is important for the activation of NK cells. NK cells are also activated by IFN- $\gamma$. The production of IFN- $\gamma$ and TNF- $\alpha$ can be induced in CMV infected cells. These cytokines protect the surrounding cells against CMV infection. Other cytokines also play an important role by directing inflammatory cells to the site of infection.

Although antibodies are not so important for the recovery of CMV infection it has been shown that the maternal humoral immune response is important in preventing CMV disease in the new-born (Fowler et al. 1992). In a vaccination study it has been demonstrated that the protection from reinfection is correlated with the presence of neutralising antibodies (Adler et al., 1995). These antibodies can neutralise free virus particles. Primary CMV infections are characterised by the production of initial $\lg M$ class antibodies. The IgM antibody production declines after a period of several weeks to months after infection The IgG class antibodies are produced after the $\lg M$ response and persist for life. Antibodies generated against 
CMV are directed against both CMV early (non-structural) and CMV late (structural) proteins. With respect to neutralisation, the viral envelope proteins appear to be the principle targets of protective antibodies like anti-gB and anti-gH antibodies (Britt et al. 1990; Marshall et al., 1992; Pereira et al., 1993; Urban et al., 1994; Urban et al., 1996).

Infection of immunocompetent individuals by CMV is usually of limited pathological consequence, but leads to persistence (the latent state) of the virus. This indicates the importance of the immune system in the recovery from disease and the control of latency ( $\mathrm{Ho}, 1991 \mathrm{a} ; \mathrm{Ho}, 1991 \mathrm{~b})$.

\section{Escape mechanisms of CMV}

The virus uses the host for its replication and consequently affects the physiology of its host, but of course the survival of the virus is ultimately linked to the survival of the host. The hast defence limits the time for the virus to replicate, therefore it is beneficiall for a virus to escape the immune surveillance of its host. A general strategy that is used by members of the herpesvirus family is the ability to reside in a state of latency. During this state a limited subset of viral genes is expressed, whereby the risk of antigen detection by the immune system of the host is minimised. Another mechanism for escaping the immune system of the host is the ability to interfere with the cell-mediated immunity. This interference can be at the level of regulating cellular activity by cytokines and receptors or by inhibiting the recognition of infected cells by cells of the immune system

\section{Cytokines and GCR receptors}

Cytokines and their receptors are critical for the initiation and co-ordination of immune responses. Immunalogical processes are characterised by a carefully regulated co-operation between different blood cells and between blood cells and the vascular wall. In the fine tuning of these processes a very broad spectrum of communication molecules like cytokines are involved.

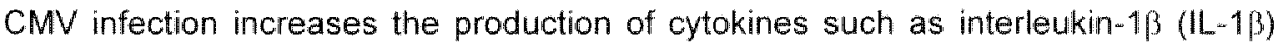
and TNF-a by monocytes (Iwamoto et al., 1990; Smith et al., 1992). These cytokines are often referred to have "antiviral" activity. On the other hand, the cytokine IL- 8 can enhance HCMV replication in fibroblasts (Murayama et al., 1994). IL-8 belongs to the $\mathrm{C}-\mathrm{X}$-C chemokines ( $\alpha$-chemokines)

CMV infection thus may interfere with cytokine production, but it also interfere with their cellular receptors. For instance, the CMV genome contains open reading frames (ORFs) coding for homologues of an important receptor family namely the G- 
protein coupled receptors (GCR). The predominant function of cellular GCR is the transduction of signals across the cell membrane by activation of the associated $G$ proteins. The ligands for cellular GCR, are hormones, neurotransmitters and chemokines. HCMV contains an open reading frame (ORF) termed US28 that has an overall amino acid homology of $33 \%$ with the mammalian IL-8 receptor. The US28 viral receptor binds members of the C-C chemokine family (Gao and Murphy, 1994), and triggers a $\mathrm{Ca}^{2+}$ flux in response to $\beta$-chemokines (Gao and Murphy, 1994). HCMV US27 is a second GCR homologue that displays a significant homology to $\beta$-chemokine receptors (Chee et al, 1990b). UL 33 is the third GCR homologue identified in HCMV. The ligands for UL33 are not determined yet. There is a great deal of speculation about the biological significance of the GCR homologues. One possible function might be the reduction of the concentration of the chemokine at the site of virus infection. Since the HCMV US 28 is a functional chemokine receptor which binds specific chemokines it is possible that through the binding of chemokines to this receptor the concentration of the chemokines are reduced which might lead to a reduced influx of immune effector cells at the site of infection (Michelson et al. 1997). Another possibility is that the expression of the viral GCR in response to their ligands modifies the behaviour of infected cells. The viral GCR could trigger changes of the intracellular environment beneficial for virus replication.

\section{Modulation of the MHC class I molecules}

The first line of defence against most viruses is the recognition and destruction of the infected cells by natural killer cells and virus specific cytolytic $T$ lymphocytes. CTLs recognise virus infected cells through $\mathrm{MHC}$ class I molecules that present viral antigens on the surface of the infected cells. The antigens are derived from products of degradation of viral proteins, which occurs in the cytosol. After degradation, antigenic peptides are transported into the endoplasmatic reticulum, where they are assembled with class I MHC molecules. The antigens are transported via the vesicular systems to the cell surface. Recognition of these complexes by CTLs leads to $T$ cell activation, resulting in lysis of the infected cells and in the production of cytokines and growth factors for the expansion of the virus specific CTL population. HCMV is able to modulate the MHC class I expression. After infection with HCMV the expression of MHC class I molecules on the cell membrane is drastically reduced, abrogating the presentation of viral antigens. Two HCMV genes, US2 and US11, are involved in the degradation of the MHC class I molecules (Jones et al., 1995). The HCMV glycoprotein US3 also induces a downregulation of expression of MHC class I molecules at the surface of the cells, but this reduction is not caused by 
the degradation of the molecule but by the fact that the MHC class I molecules are retained in the endoplasmatic reticulum (ER) (Ahn et al. 1996; Jones et al. 1996). Downregulation of MHC class I molecules leads to activation of NK cells. Conversely, NK cells are capable of lysing cells with little or no MHC class I molecules. As described above CMV downregulates the expression of MHC class I mollecules. This would then paradoxically render the infected cels more susceptible for NK Iysis, but HCMV has an ORF termed UL18 that has been identified as a homologue of MHC class I molecule (Beck and Barrell, 1988). The MHC class I homologue has the potential to inhibit the lysis of infected cells by NK cells (Farrell et al., 1997; Reyburn et al. 1997). It exhibits a high homology with the beta 2microglobulin binding domain of MHC class | proteins. The UL18 product can associate with human beta 2-microglobulin (Browne et al., 1990) and can bind endogenous peptides (Fahnestock et al., 1995). In addition, it can bind to a novel immunoglabulin superfamily glycoprotein, designated Leukocyte Immunoglobulinlike Receptor (Cosman et al., 1997 ).

\section{Fc receptor}

Immunoglobulins contain a Fab fragment that binds antigens, and a Fo fragment that interacts with cells of the immune system. Neutrophilic polymorphonuclear leukocytes and macrophages contain Fc receptors on their cell membrane to which the Fc fragment of the immunoglobulin molecule binds, when that immunoglobulin is bound to a pathogen.

Cells infected with CMV are also able to bind the $\mathrm{Fc}_{\mathrm{C}}$ portion of immunoglobulin $\mathrm{G}$ (lgG) (Frey and Einsfelder, 1984). The viral Fc receptor (FcyR) is located on the tegument of the HCMV virion. Through this receptor the virus is able to bind human immunoglobulin $\mathrm{G}$ ( $\mathrm{lgG}$ ) (Stannard and Hardie, 1991). The human cytomegalovirus induced FcyR appears to be different from that found in the $\alpha$-herpesviruses and from the murine CMV induced FcyRs, since the HCMV FcyR genome contains no sequence homology with the genes coding for $\alpha$-herpesvirus and murine CMV Fc receptors (Thale et al., 1994; Thale et al, 1995). Furthermore, the HCMV FCyR differs from the human $\mathrm{gG} F \mathrm{~F}$ receptors, as indicated by the observation that antibodies directed against these receptors do not react with the HCMV induced $F C$ receptor (MacCormac and Grundy, 1996).

The functional role and the chemical nature of these HCMV-induced Fc receptors still has to be elucidated. These receptors may protect the infected cells from antibody-mediated destruction by binding the Fc-fragment of non-virus specific antibody, thereby preventing the attachment of specific antiviral lgG (Adler et all. 1978). 


\section{Vascular involvement}

There is increasing evidence that CMV is involved in vascular pathology. Infected capillaries and venules have been described in a variety of organs, such as brain (Wiley and Nelson, 1988), lung (Bautista and Sedmak, 1995), heart (Arbustini et al., 1992), and gastrointestinal tract (Francis et al., 1989).

The first evidence for the involvement of CMV in the vascular pathology was found by the group of Melnick (Melnick et al., 1995), who described the relation between the presence of HCMV and atherosclerosis. Epidemiological studies and studies on the detection of the virus in atherosclerotic plaques support this relationship (Hendrix et al., 1989; Nieto et al, 1996). Melnick describes a working hypothesis to explain CMV induced atherosclerosis. In this model the activation of endothelium is the trigger which is followed by a whole cascade of events involving monocytes, lymphocytes, cytokines and growth factors (Melnick et al., 1995).

Recently it has been described that CMV infection is correlated with coronary restenosis in patients undergoing angioplasty (Speir et al., 1994). Restenosis is characterised by vessel renarrowing by excessive proliferation of smooth muscle cells. In approximately one third of these patients with restenosis CMV DNA is detected. Smooth muscle cells from the lesions express a virus immediate early protein (IE 84) which binds and inhibits the p53 tumour suppressor gene product. This may enhance the proliferation of smooth muscle cells or inhibit apoptosis (Speir et al., 1994). However, in restenosis lesions of the internal carotid artery no HCMV DNA could be detected with PCR (Pauletto et al. 1996). Furthermore, no accumulation of $\mathrm{p} 53$ protein in the coronary arteries of HCMV-positive transplantation patients suffering from accelerated graft arteriosclerosis was detected (Baas et al., 1997). Thus the involvement of CMV in the proliferation of smooth muscle cells in restenosis and accelerated graft arteriosclerosis is still a matter of debate.

Transplant-associated arteriosclerosis (TAA) or chronic rejection affects all vessels in the transplanted organs in the long run (Billingham, 1992). TAA is characterised by persistent, mainly perivascular inflammation and concentric intimal thickening (Hayry et al., 1995). The initiation and progression of TAA is not fully understood. Both antigen dependent and antigen independent factors seem to be involved in the 


\section{Allograft arteriosclerosis}
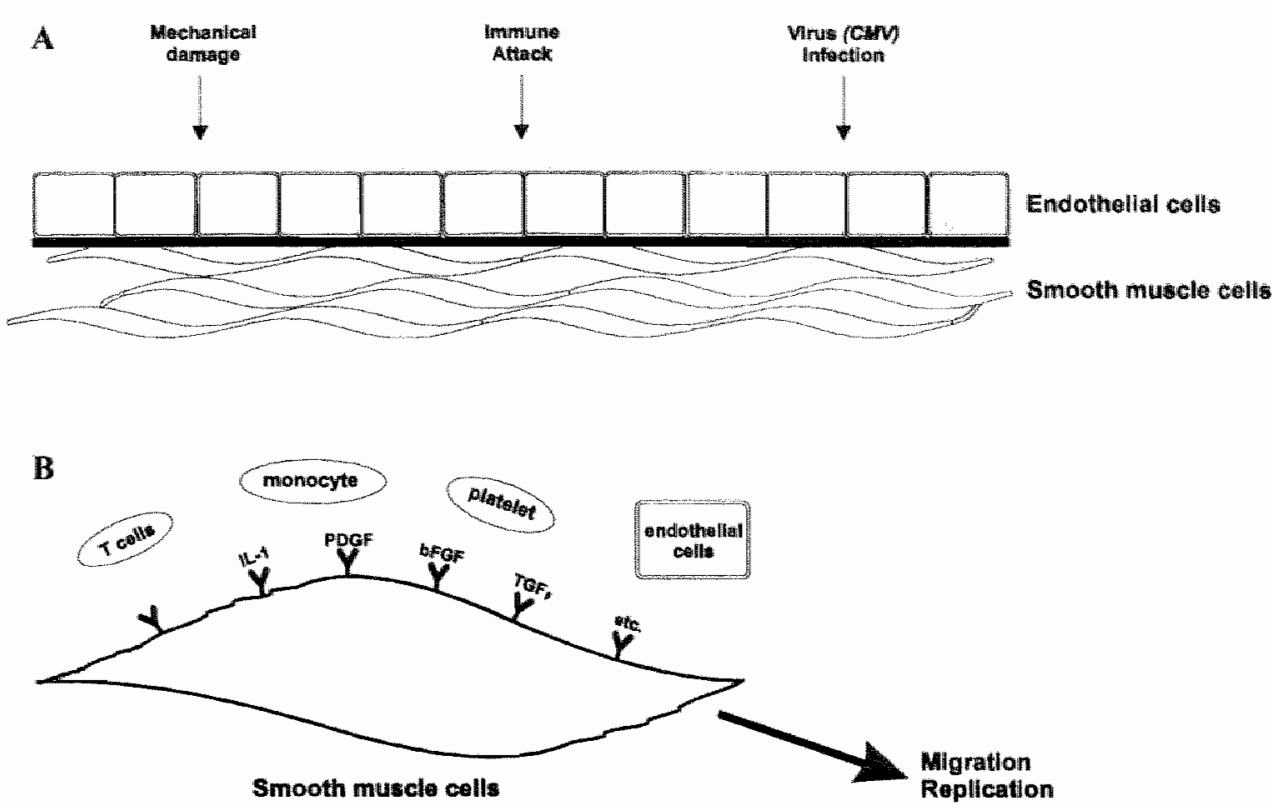

Fig.2 Endothelial damage is caused through mechanical damage, immune attack, virus infection and other parameters (A).

This damage induces the accumulation of inflammatory cells, $T$ cells, monocytes and platelets. and induces the secretion of various growth-promoting peptides by endothelial cells. As a consequence of the responses of the inflammatory cells and endothelial cells, smooth muscle cells are induced to replicate and migrate (B)

development of TAA (Duijvenstein and van Breda Vriesman, 1991, Hosenpud et al., 1995). The histocompatibility between the donor and the recipient appears to be an important factor in this process, since in syngeneic grafts hardly any arteriosclerotic changes are found (Cramer et al., 1989).

Furthermore, it is believed that T-cells, monocytes and macrophages are involved in the injury of endothelial cells and that antibodies have a synergistic effect on this process (Colvin, 1991). Antigen dependent factors which induce endothelial injury are prolonged cold ischemia and infections (Rose et al., 1989, Scholz et al., 1996, Land, 1994). The persistence of perivascular inflammation damages the vascular endothelium. The vascular endothelial cells respond to the injury by secreting growth factors to repair the damage. Several studies indicate that overexpression of acidic and basic fibroblast growth factors, transforming growth factor and platelet derived growth factor is found in vessels of transplanted organs. Growth factors like 
transforming growth factor $\beta$ are involved in the proliferation of smooth muscle cells, via an NF-kB-dependent mechanism (Bellas et al., 1995). As a consequence of growth factor expression vascular smooth muscle cells replicate and migrate from the media into the intima. Another characteristic of TAA is the influx of $T$ lymphocytes and monocytes (Lemstrom et al., 1993, Li et al., 1995). Damage of the vascular endothelium induces the expression of adhesion molecules like ICAM-1 and VCAM-1 on endothelial cells, which lead to adhesion and infiltration of leukocytes into the vessel wall (Tanaka et al., 1994). These infiltrating activated monocytes and macrophages produce cytokines like TNF- $\alpha$ and IL-1 $\beta$ which activate endothelial cells and smooth muscle cells by a NF-kB- dependent mechanism (Schreck et al., 1992).

TAA seems to be caused by a complex mixture of cellular interactions, which is controlled by a wide variety of regulating factors. The regulatory molecules in chronic rejection appear to be cytokines, eicosanoids and particular peptide growth factors, synthesised by endothelial cells in response to injury (Häyry et al., 1995) such as caused by CMV infection. This indicates that chronic rejection is an immunomediated process which is caused and amplified by multiple factors.

In summary, CMV seems to have an accelerating effect on transplant-associated arteriosclerosis, but the mechanism for this effect is not completely understood (Grattan et al., 1989; Loebe et al., 1990; Koskinen et al., 1993). Various mechanisms could play part: It has been described that CMV induces the production of cytokines and enhances the influx of lymphocytes, monocytes and macrophages (Bruggeman et al., 1995). CMV infection also enhances the expression of growth factors in the smooth muscle cells (Lemström et al., 1994).

\section{Endothelium}

The endothelium forms a border between the vascular lumen and surrounding tissues. Due to this crucial location, the endothelium is involved in the regulation of vessel tone and in various vital processes like, vessel growth, leukocyte traffic, platelet activation, coagulation and fibrinolysis (Pearson, 1993). In their basal state endothelial cells exert a thromboresistant and vasodilatator influence on the cardiovascular system (Vane et al, 1990; Vallance et al., 1997). Endothelial cells support two major antithrombotic mechanisms: 1) The antithrombin III pathway by expressing anticoagulant heparan sulphate on their surface (Rosenberg and Rosenburg, 1984). The binding of antithrombin III to the heparan sulphate presented in the endothelium surface increases its affinity for thrombin. 2) The protein $C$ pathway by expressing thrombomodulin and secreting protein $S$ (Pober and Cotran, 1990). Activated protein $C$ inactivates clotting factors VIIla and Va. Protein S, which 
is synthesised and secreted by the endothelium, enhances the catalytic action of protein C (Pearson, 1993). Endothelial cells also inhibit platelet aggregation by the synthesis and secretion of prostacyclin and induce vasodilation by releasing endothelium-derived rellaxing factor, now recognised as nitric oxide. These two agents act synergistically (Pearson, 1993; Moncada and Higgs, 1995)

Endothelial cells can be activated by a variety of agents or factors, such as certain bacteria, viruses, cytokines, oxidised low density lipoproteins, immune complexes, and activated $B$ and $T$ cells as well as physical and oxidative stress (Hunt and Jurd, 1997). The main changes in activated endothelium are the induction of procoagulant activity, the expression of cell-surface adhesion molecules, the production of cytokines and the upregulation of HLA molecules resulting in the loss of vascular integrity. The activation of endothelial cells can be divided into two phases. The first phase takes place within seconds, during which retraction of the endothelial cells, expression of P-selectin and the release of von Willebrand factor occur. The second stage lasts hours before an effect is observed, because gene transcription and protein synthesis are required. Genes for E-Selectin, intercellular cell adhesion molecule-1, vascular adhesion molecule-1 and proinflammatory cytokines including interleukin-6 are then transcribed (Hunt and Jurd 1997). The increase in the expression of adhesion molecules and the increased permeability of the activated endothelium indicate the importance of endothelial cells for directing inflammatory cells to the sites of inflammation.

\section{CMV infection of endothelial cells}

Studying CMV infection of endothelial cells is important because of their strategic position at the interface between the circulation and the surrounding tissue. The endothelium is an active barrier between blood and tissue. By in vivo experiments with rats it has been shown that in the CMV infected immunocompetent host nearly no CMV containing endothelial cells are detectable (Span et al., 1993), while in immunocompromised rats CMV infected endothelium has been observed in the small vessels (Persoons et al., 1998). Also in humans the vascular endothelium especially of the microvasculature is a major target for HCMV, albeit only when high concentrations of the virus are detectable in the host as occurs in immunocompromised individuals (Sinzger et al., 1995). Because of its strategic position at the interface between organ tissues and blood circullation, the vascullar endothellum may be involved in the dissemination of CMV throughout the body Infected endothelial cells are possibly capable to pass on the wirus to transmigrating monocyte-derived macrophages. This notion was supported by the demonstration 


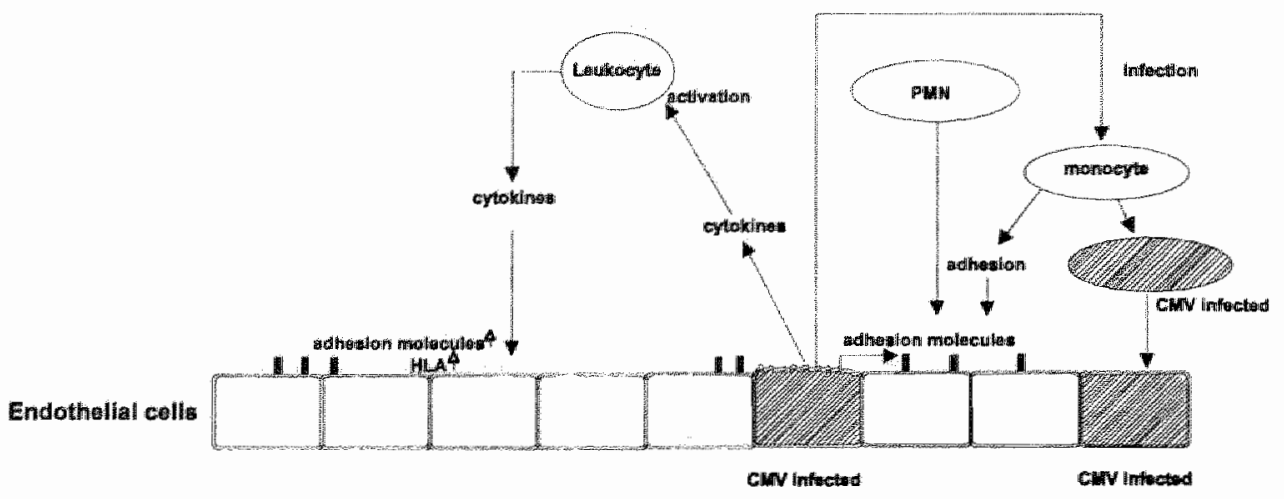

Fig.3 Interaction between CMV and endothelial cells.

that there is a bi-directional transmission between endothelial cells and monocytes (Waldman et al., 1995). Moreover, cytomegalic cells of endothelial origin have been found in blood of acutely infected immunocompromised patients (Grefte et al., 1993; Grefte et al., 1995). These circulating infected endothelial cells are giant cells with nuclear inclusions and can be trapped in the capillary bed of organs (Sinzger et al, 1995), where they might infect the capillary wall by cell to cell contact. This observation forms an additional indication for the involvement of the endothelium in HCMV pathogenesis and the haematogenous spread of CMV.

Endothelial cells play an important role as modulators of the inflammatory host reaction. Firstly, they help to direct the leukocytes to the site of infection by antigen presentation and/or by leukocyte adhesion via expression of adhesion molecules on their cell surface. CMV infection of endothelial cells induces an increase in the expression of adhesion molecules, such as ICAM-1 and E-selectin (Bruggeman and van Dam-Mieras, 1991). This subsequently leads to increased adherence of leukocytes such as, granulocytes and monocytes to these cells (Span et al., 1991a; Span et al., 1991b; Span et al., 1989).

Secondly, CMV infected endothelial cells influence the immune response by inducing the production of cytokines. Infection of endothelial cells by CMV leads to a rapid increase in the production of cytokines, like IL-1 and IL-6 in endothelial cells (Woodroffe et al., 1993, Almeida et al., 1994), but also indirect effects are described. For instance, human umbilical vein endothelial cells (HUVEC) infected with CMV are capable of activating $T$ cells from CMV-seropositive donors leading to an increase in the proliferative response and IL-2 production of these cells (Waldman et al., 1992). The activated $T$ cells, in turn, produce interferon- $\gamma$ and tumour necrosis factor, which leads to an enhancement of ICAM-1, VCAM-1 and histocompatibility leukocyte antigen (HLA) expression on the endothelial cells (Waldman and Knight, 1996). On 
the other hand, CMV is not capable of inducing HLA class II on infected human endothelial cells directly (van Dorp et al. 1989, Knight et al., 1997), and it inhibits the interferon $\gamma$-stimulated MHC class II expression (Miller et al, 1998). These results indicate that infection of endothelial cells by CMV can lead to a cascade of events, with the potential of modulating the inflammatory reaction of the host.

In vitro experiments have demonstrated that only a limited number of the endothelial cells is infected with the CMV strain AD169. The rate of infection of these endothelial cells is influenced by several factors such as virus strain and type of endothelial cells used (Waldman et al., 1989; Vossen et al., 1996). It was found that endothelial cells of the microcirculation are more permissive for CMV than cells from the larger vessels (Lathey et al., 1990; Span et al., 1993; Vossen et al., 1996). However, from the afore-described response to CMV infection one can hypothesise that a low number of infected endothelial cells may already enhance inflammation and dysfunction of the vascular wall.

Finally, inflammation of the vascular wall leads to oxidative stress which enhances the CMV replication in human endothelial cells and, in addition, has been shown to stimulate the cytokine mediated stimulation of these cells (Scholz et al., 1996). CMV replication in endothelial cells can be inhibited by the antioxidant L-ascorbic acid-2phosphate (Cinatl et al., 1995). Modulation of the intracellular thiol level in endothelial cells also affects the permissiveness for CMV (Vossen et al., 1997).

\section{Outline of this thesis}

This thesis describes an investigation of interactions between endothelial cells and HCMV. As already described in this introduction, CMV seems to be involved in atherosclerotic disease and TAA which are characterised by dysfunction and thrombostic phenomena and proliferation of the vascular intima. Chapter 2 describes a study of the influence of HCMV on the procoagulant properties of endothelial cells. This was investigated by measuring the procoagulant activity and membrane perturbation induced by HCMV infection of microvascular and macrovascular endothelial cells with different HCMV strains. In the studies described in Chapter 3 we investigated whether these responses were due to a direct or an indirect effect of the virus. It has been described before that CMV also enhances the expression of adhesion molecules which can play a role in the increased adherence of inflammatory cells to the endothelium. Therefore it was interesting to investigate if HCMV infection of endothelial cells also induces the release of chemokines.

The next three chapters focus on the mechanism of HCMV infection in human umbilical vein endothelial cells (HUVEC). HUVEC are known to have a low permissiveness for the HCMV strain AD169, whereas fibroblasts are fully permissive 
for this strain. In Chapter 4 we described our investigations of the involvement of various cellular signal transduction pathways of the HCMV infection of endothelial cells. In the Chapters 5 and 6 the entry of the virus in both cell types, the transport of the virus through the cytoplasm to the nucleus and the expression of immediate early and late-genes were compared. The objective was to study the differences in peimissiveness for AD169 between HUVEC and fibroblasts. In Chapter 7 the results obtainied are summarised and discussed with respect to the involvement of $\mathrm{CMV}$ infection in vascular disease and the role of endothelial cells in the infection process.

\section{REFERENCES}

Adler, $\mathbb{R}_{\text {, }}$ Glorioso, J.C., Cossman, J. and Levine, M. (1978) Possible role of FC receptors on ceills infected and transformed by herpesvirus: escape from immune cytolysis. Infect. Immun. 21: $442-447$

Adler, S.P., Starr, S.E., Plotkin, S.A., Hempfling, S.H., Buis, J., Manning, M.L. and Best, A.M. (1995) Immunity induced by primary human cytomegalowirus infection protects against secondary infection among women of childbearing age. J. Inf. Dis. 171: 26-32

Ahn, K., Angulo, A., Ghazal, P., Peterson, P.A., Yang, Y. and Früh, K. Human cytomegalovirus inhibits antigen presentation by a sequential multistep process. Proc. Natt. Acad Sci. USA 93, 10990-10995

Alford, C.A. and Britt, W.J. (1990) Cytomegalovirus. Virology, Raven press, New Yorlk, 1981-2010

Almeida, G.D., Porada, C.D., St Jeor, S. and Ascensao, J.L. (1994) Human cytomegalowirus alters interleukin-6 production by endothelial cells. Blood $83(2): 370-6$

Anders, D.G. and McCue, L.E. (1996) The human cytomegalovirus genes and proteins required for DNA synthesis. intervirology 39 : $378-388$

Arbustini, E., Grasso, M., Diegoli, M., Percivalle, E., Grossi, P., Bramerio, M., Campana, C., Goggi, C., Gavazzi, A. and Vigano, M. (1992) Histopathologic and molecullar profile of human cytomegalovirus infections in patients with heart transplants. Am. J. Clin. Pathof. 98(2): 205-13.

Bastas, 1.O., Offerhaus, G.J.A. and Hruban, R.H. (1997) Interactions between cytomegalovirus and the $p 53$ tumor suppressor gene in atherosclerotic vascular disease. Clin. Microbiol. Infect 3 $393-395$

Bautista, N.G. and Sadmak, D.D. (1995) Cytomegalovirus infection is associated with absence of aveolar epthelial cell HLA class II antigen expression. J. Infect. Dis. $471: 39-44$

Beck, S. and Barrell, B.G. (1988) Human cytomegalovirus encodes a glycoprotein homologous to MHC class-1 antigens. Nature 331(6153) 269-72

Bellas, R.E., Lee, J.S. and Sonenshein, G.E. (1995) Expression of a constitutive NF-kappa B-like activity is essential for proliferation of cultufed bovine vascular smooth muscle cells. $J$. Clin. Invest. $96(5): 2521-7$

Billingham, M.E. (1992) Histopathology of graft coronary disease. A. Heart Lung Transplant. 11: 538 $\$ 44$.

Britt, W.J. and Mach, M. (1996) Human cytomegalovirus glycoproteins. Interwirology 39: 401-412

Britt, W.J., Vugler, L., Butfiloski, E.J. and Stephens, E.B. (1990) Cell surface expression of human cytomegalovirus (HCMV) gp55-116 (gB): use of HCMV-recombinant vaccinia wirus-infected cells in analysis of the human neutralizing antibody response. J. Virol. 74: 1079-1085

Browne, H., Smith, G., Beck, $S_{\text {. }}$ and Minson. T. (1990) A complex between the MHC class I homologue encoded by human cytomegalovirus and beta 2 microglobulin. Nature 347(6295) $770-2$

Bruggeman, C.A., Li, F. and Stals, F.S. (1995) Pathogenicity: animal models. Scand. J. Infect. Dis. Suppll 99, 43-50 
Bruggeman, C.A. and van Dam-Mieras, M.C.E. (1991) The possible role of cytomegatovirus in atherogenesis Prog. Med. Virol. 38: 1-26

Chee, M.S., Bankier, A.T., Beck, S., Bohni, R. Brown, C.M. Cerny, R., Horsnell, T., Hutchison, C.A.d., Kouzarides, T., Martignetti, J.A. et al. (1990a) Analysis of the protein-coding content of the sequence of human cytomegalovirus strain AD469. Cury. Top. Microbiol. Immunol 154: 125-69

Chee, M.S., Satchwell, S.C., Preddie, E., Weston, K.M. and Barrell, B.G. (1990) Humam cytomegalovirus encodes three $G$ protein-coupled receptor homologues [see comments]. Nature 344(6268): 774-7

Cinati, J., Weber, B., Rabenau, H., Gumbel, H.O., Chenot, J.F., Scholz, M., Encke, A. and Doerr, H.W. (1995) in vitro inhibition of human cytomegalovirus replication in human forskin fibroblasts and endothelial cell by ascortbic acid 2-phosphate. Antiviral Res. 27: 405-418

Cole, R. and Kutner, A. (1926) A filterable virus present in the submaxillary glands of guinea pigs. $J$. Exp. Med. 44: 855-873

Colvin, R. (1991) The pathogenisis of vascular rejection. Transplant Proc. 23: 2052-2055

Compton, T. (1995) Towards a definition of the HCMV entry pathway. Scand. J. Infect. Dis. Suppl 99: $30-32$

Compton, T., Nepomuceno, R.R. and Nowlin, D.M. (1992) Human cylomegalovirus penetrates host cells by pH-independent fusion at the cell surface. Virology 194(1): $387-95$

Cosman, D., Fanger, N., Borges, L., Kubin, M., Chin, W., Peterson, L. and Hsu, M+L. (1997) A novel immunoglobulin superfamily receptor for cellular and viral MHC class I molecules. Imumunity $7,273-282$

Cowdry, E.V. and Scott, G.H. (1935) Nuclear inclusions in the kidneys of Macacus rhesus monkeys. Am. J. Pathol 11: 659m668

Cramer, D.V., Qian, S.Q., Harnaha, J., Chapman, F.A., Estes, L.W., StarzI, T.E. and Makoowaka, L. (1989) Cardiac transplantation in tha rat. The effect of histocompatibility differences on graft arteriosclerosis. Transplantation 47: 414-419

Cranage, M., Smith, G., Bell, S., Hart, H., Brown, C., Bankier, A., Tomlinson, P., Barrell, B. and Minson, T. (1988) Identification and expression of a human cytomegalovirus glycoprotein with homology to the Epstein-Barr virus BXLF2 product, varicella-zoster virus gplll, and herpes simplex virus type 1 glycoprotein $H$.J. Virol. 62: 1416-1422

Davignon, J.-L., Clement, D., Alriquet, J.M., S. and Davrinche, C. (1995) Analysis of the proliferative $T$ cell response to human cytomegalovirus major immediate-early protein (IE1): Phenotype, frequency and variability. Scand. J. Immurnol. 41:247-255

Davis-Poynter, N.J., Lynch, D.M., Vally, H., Shellam, G.R., Rawlinson, W.D., Barrell, B.G. and Farrell H.E. (1997) Identification and characterization of a $G$ protein-coupled receptor homologue encoded by murine cytomegalovirus. d. Virol. 71, 1521-1529

DoMarchi, J., Blankenship, M., Brown, G. and Kaplan, A. (1978) Size and complexity of human cytomegalovirus DNA. Wirology 89: 643-646

Dubbing, L., Haskill, S., Clark, B.D., Auron, P.E., Sporn, S. and Huang, E.S. (1989) Cytomegalovirus infection stimulates expression of monocyte associated mediator genes. $d$. Immunol. $143: 3343-3352$

Duijvenstein, A.M. and van Breda Vriesman, P.J. (1991) Chronic renal allograft rejection. Selective involvement of the glomerular endothelium in humoral immune reactivity and intravascular coagulation. Transplantation. 52: 195-202

Duncombe, A.S., Meager, A., Prentice, H.G., Grundy, J.E., Helsop, H.E., Hoffbrand, A.V. and Brenner, M.K. (1990) Gamma-interferon and tumor necrosis factor production after bone marrow transplantation is augmented by exposure to marrow fibroblasts infected with cytomegalovirus. Blood 76: 1046-1053

Fahnestock, M.L., Johnson, J.L., Feldman, R.M., Neveu, J.M., Lane, W.S. and Bjorkman, P.J. (1995) The MHC class I homolog encoded by human cytomegalovirus binds endogenous peptides. Immunity 3(5): 583-90

Farrell, H.E., Vally, H., Lynch, D.M., Fleming, P., Shellam, G.R., Scalzo, A.A. and Dawis-Poynter" N.J. (1997) Inthibition of natural killer celis by a cytomegalowirus MHC class I homoloque in vivo Nature 386: $510-514$

Fenoglio, C.M. Oster, c.M., Gerfo, P.L., Reynolds, T., Edelson, R. and Patterson, J.A.K. (1982) Karposi's sarcoma following chemotherapy for testicular cancer in a homosexual man: demonstration of cytomegaovirus RNA in sarcoma cells. Hum. Pathol 15: 955-959 
Flelds, B.N. and Knipe, D.M. (1990) Herpesviridae: A brief introduction. Virology, second edition. Raven Press, Lid. New York. 1787-1795.

Fowler, K.B., Stagno, S., Pass, R.F., Britt, W.J., Boll, T.J. and Alford, C.A. (1992) The outcome of congenital cytomegalovirus infection in relation to maternal antibody status. $N$. Engl. J. Med. 326: $663-667$

Francis, W.D., Boylston, A.W., Roberts, A.H., Parkin, J.M. and Pinching, A.J. (1989) Cytomegalovirus infection in gastrointestinal tracts of patients infected with HIV-1 or AIDS. $J$. Clin. Pathol. 42: 1055-1064

Frey, J. and Einsfelder, B. (1984) Induction of surface $\operatorname{lgG}$ receptors in cytomegalovirus-infected human fibroblasts. Eur. J. Biochem. 138(1): 213-6

Gangan, P.A., Besen, G., Mungula, D. and Freeman, W.R. (1994) Macular serous exudation in patients with acquired immunodeficiency syndrome and cylomegalovirus retinitis. Am. $d$. Ophthaimol. $118(2): 212-9$

Gao, J.L. and Murphy, P.M. (1994) Human cytomegalovirus open reading frame US28 encodes a functional beta chemokine receptor. J. Biol. Chem. 269(46): $28539-42$

Gibson, W. (1993) Molecullar Blology of Human Cytomegalowirus. New York, Springer.

Gibson, W. (1996) Structure and assembly of the virion. Interwirology 39: $389-400$

Gibson, $W_{x}$ Clopper, $K$., Britt, $W_{x}$ and Baxter ${ }^{M}$. (1996) Human cytomegalowirus" smallest capsid protein' identified as product of small open reading frame located between HCMV UL48 and UL49. J. Virol 70: 5680-5683

Goodpasture, E. and Talbot, F. (1921) Concerning the nature of "protozoan-like" cells in certain lesions of infancy. Am. J. Dis. Child. 21: 415-425

Grattan, M.T., Moreno-Cabral, C.E., Starnes, V.A., Oyer, P.E., Stinson, E.B. and Shumway, N.E. (1989) Cylomegalovirus infection is associated with cardiac allograft rejection and atherosclerosis. JAMA, 261:3561-3566

Greenberg, P.D., Reusser, P., Goodrich, J.M. and Riddell, S.R. (1991) Development of a treatment regimen for human cytomegalowirus (CMV) infection in bone marrow transplantation recipients by adoptive transfer of donor-derived CMV-specific T-cell clones expanded in vitro. Ann. NY Acad. Sci. 636:184-195

Grefte, A., Blom, N., van der Giessen, M., van Son, W. and The, T.H. (1993) Uitrastructural analysis of circulating cytomegalic cells in patients with active cytomegalovirus infection: evidence for wirus production and endothelial origin. J. Infect. Dis. 168(5): 1110-8

Grefte, J.M., van der Giessen, M., Blom, N., The, T.H. and van Son, W.J. (1995) Circulating cytomeglabvirus-infected endothelial cells after renal transplantation: possible clue to pathophysiology? Transplant. Proc. 27: 939-942

Grundy, J.E., McKeating, J.A., Ward, P.J., Sanderson, A.R. and Griffiths, P.D. (1987) Beta 2 microglobulin enhances the infectivity of cytomegalovirus and when bound to the wirus enables class I HLA molecules to be used as a virus receptor. J. Gen. Wirol. $68(\mathrm{Ft}$ 3): $793-$ 803

Haagmans, B.L., van-den-Eertwegh, A.J., Claassen, E., Horzinek, M.C. and Schijns, V.E. (1994) Tumour necrosis factor-alpha production during cytomegalowirus infection in iminuriosuppressed pats, $J$. Gen. Virol. 75(Pt 4): 779-87

Harmon, M. and Gibson, W. (1996) High molecular weight wirion proten of the human cytomegalovirus forms complex with product of adjacent open reading frames. Proc. Am. Soc. Virol., 144

Hăyry.S, Alataio, S., Myllärniemi, M., Răisänen-Sokolowski, A. and Lemström, K. (1995) Cellular and molecular biology of chronic rejection. Transplantation Proc. 27:71-74

Hendrix, M.G., Dormans, P.H., Kitselaar, P., Bosman, F. and Bruggeman, C.A. (1989) The presence of cytomegalovirus nucleic acids in anterial walls of atherosclerotic and nonatherosclerotic patients. Am. J. Pathol. 134: 1151-1157

Hersman, J., Meyers, J.D., Thomas, E.D., Buckner, C.D. and Clift, R. (1982) The effect of granulocyte transfusions on the incidence of cytomegalowirus infection after allogeneic marrow transplantation. Ann. Intern. Med. 96: 149-266

Ho, M. (1990) Epidemiology of cytomegalovirus infections. Rev Inf Dis 12 (Suppl 7): $5701-5710$

Ho, M. (1991a) Cytomegalovirus. Brology and infection. Plenum Medical book Company. New York 440 .

Ho, M. (1991b) Human cytomegalovirus infections in immunosuppressed patients. Cytomegalovinus: Biology and infection. New York: Plenum Medical Book Company, 249-300. 
Hosenpud, J.D., Everett, J.P., Morris, T.E., Mauck, K.A., Shipley, G.D. and Wagner, C.R. (1995) Cardiac allograft vasculopathy. Association with cellomediated bull not humoral allommunity to donor-specific wascular endothelium. Circulation 92: 205-211

Hunt, B.J. and Jurd, K.M. (1997) Relation between endothelial-cell activation and infection, inflammation and infarction. Lancet 350: 293

Irmiere, A. and Gibson, W. (1983) Isolation and characterization of a non-infectious virion-like particle released from cells infected with human strains of cytomegalovirus. Virology 130:118-133

Irmiere, A. and Gibson, W. (1985) Isclation of human cytomegalovirus intranuclear capsids, characterization of their protein constituents, and demonstration that the B-capsid assembly protein is also abundant in non-infectious enveloped particles. J. Virol $56: 277-283$

Iwamoto, G.K., Monick, M.M., Clark, B.D., Auron, P.E., Stinski, M.F. and Hunninghake, G.W. (1990) Modulation of interleukin 1 beta gene expression by the immediate early genes of human cytomegalovirus. 1. Clin. Invest. 85(6): 1853-7

Jacobson, M.A. and Mills, J. (1988) Serhous cytomegalovirus disease in the aquired immunodeficiency syndrome (AIDS). Ann. Intern. Med. 108: 585-549

Jahn, G., Kouzarides, T., Mach, M., Scholl, B., Plachter, B., Traupe, B., Preddle, E., Satchwell, S., Fleckenstein, B. and Barrell, B. (1987) Map position and nucleotide sequence of the gene for the large structural phosphoprotein of human cytomegalovirus. J. Virol. 61: 1358. 1367

Jones, T.R., Hanson, L.K., Sun, L., Slater, J.S., Stenberg, R.M. and Campbell, A.E. (1995) Multiple independent loci within the human cytomegalovirus unique short region down-regulate expression of major histocompatibility complex class I heavy chains. $J$. Virol $69(8): 4830-41$

Jones, R.T., Wiertz, E.J.H.J., Sun, L., Fish, K.N., Nelson, J.A. and Ploegh, H.L. (1996) Human cytomegalovirus US3 impairs transport and maturation of major histocompatibility complex class I heavy chains. Proc. Natl. Acad. Sci. USA 93, 11327-11333

Kasten, M.B., Canman, C.E. and Leonard, C.J. (1995) p53, cell cycle control, and apoptosis: implications for cancer. Cancer Metastasis Rev. 14:3-15

Keay, S. and Baldwin, B. (1991) Anti-idiotype antibodies that mimic gp86 of human cytomegalovirus inhibit viral fusion but not attachment. J. Virol. 65(9): 5124-8

Keay, S. and Baldwin, B. (1992) The human fibroblast receptor for gp86 of human cytomegalovirus is a phosphorylated glycoprotein. S. Virol. 66(8): 4834-8

Keay, S., Merigan, T.C. and Rasmussen, L. (1989) Identification of cell surface receptors for the 86kilodalton glycoprotein of human cytomegalovirus. Proc Natl. Acad. Sci. USA 86: 1010010103

Kilpatrick, B. and Huang, E. (1977) Human cytomegalovirus genome: partial denaturation map and organisation of genome sequences. J. Virol. 24: 261-276

Knight, D.A., Waldman, W.J. and Sedmak, D.D. (1997) Human cytomegalowirus does not induce human leukocyte antigen class II expression on arterial endothelial cells. Transplantation 63(9): $1366-9$

Koskinen, P.K., Nieminen, M.S., Krogerus, L.A., Lemstrom, J.B., Mattila, S.P., Hayry, J.P. and Lautenschlager, I.T. (1993) Cytomegalovirus infection and the accelerated cardiac allograft vasculopathy in the lhuman cardiac allografts. J. Heart Lung Transpl. 12:724-729

Kovacs, A., Weber, M.L., Burns, L.J., Jacob, H.S. and Vercellotti, G.M. (1996) Cytoplasmic sequestration of $p 53$ in cytomegalovirus infected human endothelial cells. Am. J. Pathology 149: $1531-1539$

Land, W. (1994) The potential impact of the reperfusion injury on acute and chronic rejection events following organ transplantation. Transplant Proc 26: 3169-3171

Lathey, J.L., Wiley, C.A., Verity, M.A. and Nelson, J.A. (1990) Cultured human brain capillary endothelial cells are permissive for infection by human cytomegalowirus. Virology 176(1): 266-73

Lehner, R., Meyer, H. and Mach, M. (1989) Identification and characterization of a human cytomegalovirus gene codting for a membrane protein that is conserved amoung human herpesviruses. J. Wirol. 63: 3792-3800

Lemström, K.B., Aho, P.T., Bruggeman, C.A. and Hayyry, P.J. (1994) Cytomegalovirus intection enhances mRNA expression of platelet-derived growth factor- $B$ and transforming growth factor-beta 1 in rat aortic allografts. Possible mechanism for cytomegalovirus-enhanced graft arteriosclerosis. Anterioscler. Thromb. 14(12): 2043-52 
Lemström, K.B.; Bruning, J.H., Bruggeman, C.A., Lautenschlager, I.T. and Hayry, P.J. (1993) Cytomegalovirus infection enhances smoath muscle cell proliferation and intimal thickening of rat aortic allografts. J. Clin. invest 92: 549-558

$L_{i}, F$, Grauls, $G_{.,}$Yin, $M$. and Bruggeman, C.A. (1995) Initinal endothelial injury and cylomegalowirus infection accelerate the development of allograft arteriosclerosis. Transplant Proc 27: 3552-3554

Loebe, $M_{\text {.y }}$ schuler, 5., Zais, O., Warnecke, H., Fleck, E. and Hetzer, R. (1990) Role of cytomegalowius infection in the development of coronary artery disease in the transplanted heart. J. Heart Transplant. 9: 707.711

MacCormack, L.P. and Grundy, J.E. (1996) Human cytomegalovirus induces an FCy Receptor (FcyR) in endothelial cells and fibroblasts that is distinct from the human cellular ForRs. $J$. Inf. Dis. 174: 1151-1161

Mach, M., Utz, $U$. and Fleckenstein, $B$. (1986) Mapping of the major glycoprotein gene of thuman cytomegalowirus. J. Gen. Virol 67: 1461-1467

Malraux, A. (\$992) The family herpeswiridea: an update. Arch. Virol 123; 425-449

Marshall, G.S., Rabalais, G.P., Stoutt, G.G. and Waldeyer, S.L. (1992) Antibodies to recombinantderived glycoprotein $B$ after natural human cytomegalovirus infection correlate with neutralizing activity. J. Inf. Dis. 165: $381-384$

Mcgeoch, D.J., Cook, S., Dolan, A., Jamieson, F.E. and Telford, E.A.R. (1995) Molecular phylogeny and evolutionary timescale for the family of mammalian herpersviruses. $J$. Mol. Biol. 247: $443-458$

Meier, J.L. and Stinskl, M.F. (1996) Regulation of human cytomegalowirus immediate-early gene expression. Intervirology $39: 331-342$

Melnick, J.L., Adam, E. and DeBakey, M.E. (1995) Cytomegalovirus and atherosclerosis. Bioassays 17(10): 899-903

Michelson-Fiske, S., Hoodniceanu, F. and Guillon, J.C. (1997) Immediate early antigens in human cytomegalowirus infected cells. Nature 270,615-617

Michelson, S., Dal Monte, P., Zipeto, D., Bodaghi, B., Laurent, L., Oberlin, E., ArenzanaSeisdedos, F., Virellzier, J.-L. and Landini, M.P. (1997) Modulation of RANTES production by human cytomegalowirus infection of fibroblasts. J. Virol. 71: 6495-6500

Miller, D.M. and Sedmak, D.D. (1998) Cytomegalovirus presistence: escape from cell-mediated immumosurveillance. General aspects of CMV-mediated immunomodulation with respect to pathogenesis. CMV-relaled immunopathology. Monogr Virol. Basel, Krager, 21, 1-11.

Miller, D.M. and Sedmak, D.D. (1998) Cytomegalovirus presistence: escape from cell-mediated immunosurveillance. General aspects of CMV-mediated immunomodulation with respect to pathogenesis. CMV-related immunopathology. Monogr Virol. Basel, Krager, 21, 1-11.

Mocarski, E. (1996) Cytomegaloviruses and their replication. Fields Virology (Raven Publishers) 2 : $2447-2492$

Mocarski, E.\$. (1993) Cytomegalowirus biology and replication. In Roizman B, Whitley R, Lopez C. eds. The human herpeswiruses. New York. NY: Raven Press Publishers, 173-226.

Moncada, S. and Higgs, E.A. (1995) Molecular mechanisms and therapeutic stratergies related to nitric oxide. FASEB J 9: 1319-13.30

Moore, P.S. and Chang, Y. ("995) Detection of herpesvirus-like DNA sequence in karposi's sarcoma in patients with and without HIV infection. N. Engt. J. Med. 332(18): 1181-1185

Murayama, T., Kuno, Ko, Jisaki, F., Obuchi, M., Sakamuro, D., Furukawa, T., Mukaida, N, and Matsushima, K. (1994) Enhancement human cytomegalovirus replication in a human lung fibroblast cell line by interleukin-8. J. Virol 68(11): $7582-5$

Newcomb, W.W., Trus, B.L., Booy, F.P., Steven, A.C., Wall, J.S. and Brown, J.C. (1993) Structure of the herpes simplex virus capsid: Molecular composition of the pentons and the triplexes. J. Mol. Biol. 232: 499-511

Nieto, F.J., Adam, E. Sorlie, P., Farzadegan, H., Melnick, J.L., Comstock, G.W. and Szklo, M. (1996) Cohort study of cytomegalovirus infection as risk factor for carotid intimal-medial thickening, a measure of subclinical atherosclerosis. Circulation 94: $922-927$

Nowlin, D.M., Cooper, N.R. and Compton, T. (1991) Expression of a human cytomegalovirus receptor correlates with infectibility of cells. J. Virot. 65(6). 3114-21

Pass, R.F., Hutto, R. and Cloud, G.A. (1986) Increased rate of cytomegalovirus infection amoung parents of children attending day-care centers. $N$. Engl. d. Med. 314: 1414-1418 
Pauletto, P. Pisoni, G. Boschetto, R., Zoleo, M., Pessina, A.C. and Palu, G. (1996) Human cytomegalovirus and restenosis of the internat carotid artery. Stroke 27: 1669-1671

Pearson, J.D. (1993) The control of production and release of haemostatic factors in the endothelial cell. Baillieres Clin. Haematol 6(3): 629-51

Pereira, L., Hoffman, M., Gallo, D. and Cremer, N. (1982) Monoclonal antibodies to human cyomegalovirus: three surface membrane proteins with unique immunological and electrophoretio properties specify cross-reactive determinants Infect. Immunity 36 : $924-932$

Pereira, L., Navarro, D. and Jahn, G. (1993) Proteins of human cytomegalovirus that ellict humoral immunity. In: Molecular aspects of human cytomegalovirus disease. Y. Becker, G. Darai and E-S. Huang, editors. Springer Verlag Berlin. $437-464$

Persoons, M.C.J., Stals, F.S., van Dam-Mieras, M.C.E. and Bruggeman, C.A. (1998) Multiple organ inwowement during expermental cytomegalovirus infection is associated with disseminated vascular pathology. I. Pathol 184: 103-109

Plachter, B. Wieczorek, L., Scholl "B., Ziegelmaier, R. and Jahn, G. (1992) Detection of cytomegalovirus antibodies by an enzyme-linked immunoabsorbent assay using recombinant polypeptides of the large phosphorylated tegument protein pp $150 . \mathrm{J}$. Clin. Microbiol. $30: 20+-206$

Pober, J.S and Cotran, R.S. (1990) Cytokines and endothelial cell biology. Physiol. Rev. 70(2): 42751

Pouteil-Noble, C., Ecochard, R., Landrivon, G., Donia-Maged, A., Tardy, J.C., Bosshard, S., Colon, S., Betuel, H., Aymard, M. and Touraine, J.L. (1993) Cytomegalovirus infection -an etiological factor for rejection? A prospective study in 242 renal transplant patients. Transplantation 55(4): $851-7$

Reddehase, M.J. and Koszinowski, U.H. (1984) Significance of herpesvirus immediate early gene expression in cellular immunity to cytomegalovirus infection. Nature $312,369-37 \%$

Reusser, P., Riddell, S.R., Meyers, J.D. and Greenberg, P.D. (1991) Cytotoxic T-lymphocyte response to cytomegalovirus after thuman allogeneic bone marrow transplantation: pattern of recovery and correlation with cytomegalovirus infection and disease. Blood 78: 1373-1380

Reyburn, H.T., Mandelboim, O., Davis, D.M., Pazmany, L. and Strominger, J.L. (1997) The class I MHC homologue of human cytomegatovirus inhibits attack by natural killer cells. Nature 386 : 514-517

Reynolds, D.W., Stagno, S., Hosty, T.S., Tiller, M. and Alford, C.A. (1973) Maternal cylomegalowirus excretion and perinatal infection. N. Engl. J. Med. 289: 1-5

Riddell, S.R $_{n}$ and Greenberg, P.D. (1994) Therapeutic reconstitution of human viral immunity by adoptive transfer of cytotoxic $T$ lymphocyte clones. Current Topics in Microbiology and Immunology 189: 9-34

Riddell, S.R. and Greenberg, P.D. (1995) Principles for adoptive T cell therapy of human wiral diseases. Ann. Rev. Immunal 13: 545-586

Roizman, B. (1996) Herpes simplex wiruses and their replication; Fieids Wrology (Lippincott-Raven) 2, 2231-2295.

Rose, R.M., Pinkston, p. and Skornik, W.A. (1989) Altered suseptibility to viral respiratory infection during shortuterm exposure to nitrogen dioxide. Ras. Rep. Health Eff. Inst. 24: 1-24

Rosenberg, R.D. and Rosenburg, J.S. (1984) Natural anticoagulant mechanisms. J Cin Invest 74 : $1-5$

Rowe, W. Hartley, J., Waterman, S., Turner, H. and Huebner, R. (1956) Cytopathogenic agent resembling human salivary gland virus recovered from tisue cultures of human adenoids. Proc. Sac. Exp. Biol. Med 92 : 418-424

Rubin, R.H. (1988) Infections after renal and liver transplantation. Clinical approach to infection irithe immunocompromised hast. New York London: Plenum Press, 557-583.

Ruger, B., Klages, S., Walla, B., Albrecht, J., Fleckenstein, B., Tomlinson, P. and Barell, B. (1987) Primary structure and Iranscrition of the genes coding for the two virion phosphoproteins pp65 and pp71 of human cytomegalovirus. J Virol $61: 446-453$

Scholz, M., Cinatl, J., Gross, V., Vogel, J.-U., R.A., B., Freisleben, H.J., Markus, B.H. and Doerp, H.W. (1996) limpact of oxidative stress on human cytomegalovirus replication and on cytokine mediated stimulation of endothelial cells. Transplantation 61: 1763 1770

Schreck, R., Albermann, K. and Baeuerle, P.A. (1992) Nuclear factor kappa B: an oxidative stressresponsive transcription factor of eukaryotic cells. Free Radic. Res. Commun. 17:221-237 
Severi, B., Landini, M. P. and Govoni, E. (1988) Human cylomegalovirus morphogenesis: An witrastructural study of the late cytoplasmic phases. Arch. Virol $98: 51-64$

Sinzger, C. Grefte, A., Plachter, B., Gouw, A.S.H., The, T.H. and Jahn, G. (1995) Fibroblasts, epithelial cells, endothelial cells and smooth muscle cells are major targets of human cytomegalowirus infection in lung and gastointestinal tissues. J. Gen. Virol. 76: 741-750

Sinzger, C., Muntefering, H., Loning, T., Stoss, He, Plachter, B. and Jahn, G. (1993a) Cell types infected in human cytomegalowirus placentitis identified by immunohistochemical double staining. Virchows Arch. Am. Pathol. Anat. Histopathol. 423(4): 249-56

Sinzger, C., Plachter, B., Stenglein, S. and Jahn, G. (1993b) Immunohistochemical detection of viral antigens in smooth muscle, stromal, and epithelial cells from acute human cylomegalovirus gastritis. U. nfect. Dis. 167(6): 1427-32

Smiley, M.L., Mar, E.C. and Huang, E.S. (1988) Cytomegalovirus infection and virallinduced transformation of human endothelial cells. J. Med. Virol. 25(2) 213-26

Smith, M. (1956) Propagation in tissue cultures of a cytopathologenic virus from human salivary gland virus (SGV) disease. Proc. Soc. Exp. Biol Med. 92: 424-430

Smith, P.D., Saini, S.S., Raffeld, M., Manischewitz, J.F. and Wahl "S.M. (1992) Cylomegalowirus induction of tumor necrosis factor-alpha by human monocytes and mucosal macrophages. $J$. Clin. Invest. 90(5): 1642-8

Soderberg, C., Giugnil, T.D., Zaila, J.A., Larsson, S., Wahlberg, J.M. and Moller, E. (1993) CD13 (human aminopeptidase $\mathbb{N}$ ) mediates human cytomegalovirus infection. J. Virol. 67(11): $6576-85$

Somogyi, T, Michelson, S. and Masse, M. (1990) Genomic location of a human cytomegalowirus protein with protein kinase activity (PK68). Virology 174: 276-285

Span, A.H., Frederik, P.M., Grauls, G., van Boven, G.P. and Bruggeman, C.A. (1993) CMV induced vascular injury: an electron-microscopic study in the rat. In Vivo 7: $567-573$

Span, A.H., Mullers, W., Miltenburg, A.M. and Bruggeman, C.A. (1991a) Cytomegalovirus induced PMM adherence in relation to an ELAM-1 antigen present on infected endothelial cell monolayers. Immunology $72(3): 355-60$

Span, A.H., van Dam Mieras, M.C., Mullers, W., Endert, J., Muller, A.D. and Bruggeman, C.A. (1991b) The effect of wirus infection on the adherence of leukocytes or platelets to endothellial cells. Eur. J. Clin. Invest. 21(3): 331-8

Span, A.H.M., Endert, J, van Boven, C.P.A. and Bruggeman, C.A. (1989) Virus induced adherence of monocytes to endothelial cells. FEMS Microbiol. Immunol. 47: 327-241

Speilr, E., Modall, R., Huang, E.S., Leon, M.B., Shawl, F., Finkel, T. and Epstein, S.E. (1994) Potential role of human cytomegalovirus and p53 interaction in coronary restenosis [see comments]. Science 265(5170): 391-4

Staczek, J. (1990) Animal cytomegalowiruses. Microbiol. Rev. 54: 247-265

Stagno, S., Pass, R.F. and Dworsky, M.E. (1982) Congenital cytomegalovirus infection: the relatiwe importance of primary and recurirent matemal infections. N. Engl. J. Med. 306: 945-949

Stagno, S., Reynolds, D.W., Pass, R.F. and Alford, C.A. (1980) Breast milk and the risk of cytomegalowirus infection. N. Engl. W. Med. 302: 1073-1074

Stannard, L.M. and Hardie, D.R. (1991) Ain FC receptor for human immunoglobulin G is lacated with in the tegument of human cytomegalowirus. J. Virol. $65(6): 3411-5$

Stenberg, R.M. (1996) The human cytomegalovirus major immediate-early gene. Intervirology 39 : $343-349$

Sterner, G., Agell, B.O., Wahren, B. and Espmark, A. (1970) Acquired cytomegalovirus infection in older children and adults. Scand. J. Infect. Dis. 2: $95-103$

Tanaka, H., Sukhova, G.K., Swanson, S.J., Cybulsky, M.I., Schoen, F.J. and Libby, P. (1994) Endothelial and smooth muscle cells express leukocyte adhesion molecules heterogeneously during acute rejection of rabbit cardiac allografts. Am. J. Pathol. 144(5): 938-51

Taylor, H.P. and Cooper, N.R. (1990) The human cytomegalowirus receptor oin fibroblasts is a 30 kilodalton membrane protein. J. Virol. 64(6): 2484m90

Thale, R., Lucin, P., Schneider, K., Eggers, M. and Koszinowski, U.H. (1994) Identification and expression of a murine cytomegalovirus early gene coding for an $\mathrm{FC}_{\mathrm{C}}$ receptor. It Virol $68(12): 7757-65$ 
Thale, R., Szepan, U., Hengel, $H_{\text {, }}$ Geginat, $G_{.,}$Lucin, P. and Koszinowski, U.H. (1995) Identification of the mouse cytomegalovirus genomic region affecting major histocompatibility complex class I molecule transport. J. Wirol. 69(10):, 6098-105

Toorkey, C.B. and Carrigain, D.R. (1989) Immunohistochemical detection of an immediate early antigen of human cytomegalovirus in normal tissues. J. Infect. Dis. 160: $741-751$

Urban, M., Winkler, T., Landini, M.P., Britt, W. and Mach, M. (1994) Epitope-specific distribution of IgG subclasses against antigenic domains on glycoproteins of human cylomegatovirus. $J$. Infect. Dis. 169: $83-90$

Urban, M.K., M., Britt, W.J., Haßfurther, E. and Mach, M. (1996) Glycoprotein $H$ of human cytomegalovirus is a major antigen for neutralizing humoral immume responses. J. Gen. Virol. 77: 1537-1547

Vallance, P., Collier, J. and Bhagat, K. (1997) Infection, inflammation, and infarction does acute endothelial dysfunctio provide a link? Lancet 349: 1391-1392

van Dorp, W.T., Jonges, E., Bruggeman, C.A.D., M.R., van Es, L.A. and van der Woude, F.J. (1989) Direct induction of MHC class I. but not class II, expression on endothelial cells by cytomegalovirus infection. Transplantation $48: 469-472$

Vane, J.R., Anggard, E.E. and Botting, R.M. (1990) Regiulatory functions of the vascular endothelium. N. Engl. J. Med. 323: 27-36

Vercellotti, G.M. (1995) Potential role of viruses in thrombosis and atherosclerosis. Trends Cardiovas. Med. 5: 128-133

Vossen, R.C.R.M., Derhaag, J.G., Slobbe-van Drunen, M.E.P., Duijvenstijn, A.M., van DamMieras, M.C.E. and Bruggeman, C.A. (1996) A dual role for endothelial cells in cytomegalovirus infection? A study of cytomegalovirus infection in a series of rat endotheliai cell lines. Virus Res. 46: 65-74

Vossen, R.C.R.M., Persoons, M.C.J., Slobbe-van Drunen, M.E.p., Bruggieman, C.A. and van Dam-Mieras, M.C.E. (1997) lintracellular thiol redox status affects cytomegalovirus infection of vascular cells. Virus Res. 48: 173-183

Waldman, W.J., Adams, P.W., Orosz, C.G. and Sedmak, D.D. (1992) T lymphocyte activation by cytomegalowirus-infected, allogeneic cultured human endothelial cells. Transplantation 54(5): $887-96$

Waidman, W.J. and Knight, D.A. (1996) Cytokine-mediated induction of endothelial adhesion molecule and histocompatibility leukocyte antigen expression by activated cytomegalovirus. activated T cells. Am. J. Pathol. 148: 105-119

Waldman, W.J., Knight, D.A., Huang, E.H. and Sedmak, D.D. (1995) Bidirectional transmission of infectious cytomegalovirus between monocytes and vascular endothelial cells: an in vitro model. J. Infect. Dis. 171(2): 263-72

Waldman, W.J., Sneddon, J.M., Stephens, R.E. and Roberts, W.H. (1989) Enhanced endothelial cytopathogenicity induced by a cytomegalovirus strain propagated in endothelial cells. $J$. Med. Virol. 28(4): 223-30

Wathen, M. and Stinski, M. (1982) Temporal patterns of human cytomegalovirus franscription Mapping the viral RNAs synthesized at immediate early, early, and late times after infection. J. Virol $41: 462-477$

Weller, T., Macauley, I., Craig, J. and Wirth, P. (1957) Isolation of intrastructural inclusions producing agents from infants with ilnesses resembling cytomegalic inclusion disease. Proc. Soc. Exp. Med. 94: 4-12

Wiley, C.A. and Nelson, J.A. (1988) Role of human immunodeficiency virus and cytomegalovirus in AlDS encephalitis. Am. J. Pathol 133: 73.81

Winston, D.J., Ho, W.G., Bartoni, K., Holland, G.N., Mitsuyasu, R.T., Gale, R.P., Busuttil, R.W. and Champlin, R.E. (1988) Ganciclovir therapy for cytomegalovirus infections in recipients of bone marow transplants and other immunosuppressed patients. Rev. Infect. Dis. 10 (Suppl.3): S547-S553

Winston, D.J., Ho, W.G. and Lin, C.H. (1987) Intravenous immunoglobulin for prevention of cytomegalowirus infection and interstitial pneumonia after bone marrow transplantation. Ann. Intern. Med. 106: 12-18

Woodroffe, S.B., Garnett, H.M. and Danis, V.A. (1993) Interleukin-1 production and cell-activation response to cytomegalovirus infection of vascular endothelial cells. Arch. Wirol 133(3-4): 295-308 
Wright, J.F. Kurosky, A. and Wasi, S. (1994) An endothelial cell-surface form of annexin II binds human cytomegalovirus. Blochem. Biophys. Res. Commun. 198(3): 983-9 


\section{MEMBRANE RELATED EFFECTS IN ENDOTHELIAL CELLS INDUCED BY HUMAN CYTOMEGALOVIRUS}

A.G.M. van Geelen, M.E.P. Slobbe-van Drunen, A.D. Muller, C.A. Bruggeman and M.C.E. Van Dam-Mieras 


\section{SUMMARY}

Previously, we have reported on the increase in procoagulant activity of Human Umbilical Vein Endothelial Cells (HUVEC) after infection with human cytomegalovirus (HCMV). When using microvascular endothelial cells from foreskin (MVEC), we also observe a significant increase in membrane perturbation and a concomitant increase in procoagulant activity. This effect is both observed with a laboratory HCMV strain (AD169) with low pathogenicity for endothelium and a HUVEC adapted strain (VHL-E) that readily infects endothelial cells. We compared the membrane perturbation of two types of endothelial cells, HUVEC and MVEC with Human Embryonal Fibroblasts (HEF), being fully permissive for both strains. A membrane effect was only found in endothelial cells. Our results suggest that HCMV induces in MVEC more merocyanine-540 incorporation in the membrane than in HUVEC. The increase in the procoagulant activity induced by HCMV was more pronounced in MVEC than in HUVEC. Inactivated virus, as well as virus preincubated with heparin was unable to evoke membrane perturbation. It therefore appears that HCMV induces a rapid membrane response in vascular endothelium and that physical interaction of the virion and the endothelial cell is required to elicit this response. 


\section{INTRODUCTION}

Human cytomegalovirus (HCMV), an ubiquitous pathogen in man, is a major mortality factor in immunocompromised individuals, such as AIDS-patients (Cotte et al., 1993, Fenner et al., 1991, Gozlan et al., 1993, Ho et al, 1990), organ transplant recipients (Arbustini et al., 1992, Chen et al., 1992, Gerna et al., 1991, Weber et al., 1993) and new-born infants (Demmler et al., 1988, Lo et al., 1993). Like other herpesviruses (Liedtke et al., 1993, Mahalingam et al., 1993, Miller, 1990, Sawtell and Thompson, 1992. Tenser et al., 1993), HCMV can establish a life-long latency after initial infection. The site of latency (Hendrix et al., 1990, Smith et al., 1993, Bruggeman, 1993) and the mechanisms by which reactivation will occur are presently not understood. In immunodeficient patients, the virus reactivates, posing a life-threatening risk. HCMV has also been suggested to be a contributing factor in vascular diseases like transplantation associated arteriosclerosis (Bruggeman and van Dam-Mieras, 1991, Hajjar, 1991, Melnick and Schattner, 1992). These indications have been obtained through epidemiological (Hajjar, 1991) and pathological (Hendrix et al., 1990, Melnick et al., 1983) studies and by work in animal models (Lemström et al., 1994, Lemström et al.. 1994). Putative mechanisms by which HCMV contributes to chronic vascular disease are unknown still, but in acute HCMV infections, especially in immunosuppressed patients, the virus is detected in the microvascular endothelium of most organs (Myerson et al., 1984, Robents et al., 1989, Spach et al., 1993).

The endothelium is an important mediator of the cellular immune response both directly through antigen presentation (Burger et al., 1981, Wagner et al., 1984) and indirectly by actively contributing to the rolling (Kansas et al. "1993, Nelson et al., 1993 ) and attachment (Kuijpers and Roos, 1993) of leukocytes. We and others have reported on the alteration of several of these functions through HCMV infection of endothelial cells. Studies in our laboratory have shown that infection of endothelial cells with HCMV resulted in a marked increase in adherence of granulocytes and monocytes to endothelium while no increase in platelet adhesion was observed (Span et al., 1988, Span et al., 1991, Span et al., 1991). In addition, HCMV infection leads to enhanced expression of the adhesion molecules ICAM-1 and E-Selectin (Bruggeman and Van Dam-Mieras, 1991) and it also increases the procoagulant response (Van Dam-Mieras et al, 1987). This procoagulant response is probably the result of facilitated interaction of coagulation factors on the perturbed surface of infected endothelial cells. 
The interaction of HCMV with endothelial cells therefore provides a challenging focus of research.

We and others (Bruggeman et al., 1986, Friedman, 1989, Ho et al., 1984, Waldman et al., 1989) have reported on the limited infection rate of human umbilical vein endothelial cells (HUVEC) with HCMV laboratory strains. Dependent on the amount of viral input (MOI), up to $10 \%$ of the cells contain viral antigens with a concomitant disappearance of von Willebrand factor in the infected cells (Bruggeman et al., 1988).

In addition to HCMV strain variation, also the origin and type of endothelial cells (Lodge et al., 1991. Page et al., 1992) could be a determining factor in their responsiveness to HCMV infection. HUVEC are a frequently employed model for the study of endothelial cell function, but they appear to resemble the endothelium of the larger vessels, rather than that of the microcirculation where in vivo the virus is thought to exert its effect (Banji and Salisbury, 1978, Meyerson et al, 1984). In this report we describe the influence of HCMV infection on the procoagulant response and membrane perturbation in microvascular endothelial cells (MVEC), derived from human foreskin, and a comparison is made with HUVEC and Human Embryonal Fibroblasts (HEF).

\section{METHODS}

\section{Cells and virus}

Human Embryonal Fibroblasts (HEF, Flow 2002) were cultured in Earl's Modified Eagle Medium (EMEM), supplemented with $10 \%$ Newborn Calf serum and $50 \mu \mathrm{g} . \mathrm{ml}^{-1}$ gentamycin. Cells between passage number 20 to 25 were used for experiments. HUVEC were harvested from umbilical cords as previously described (Jaffe et al., 1973). HUVEC were cultured in plastic wells coated with fibronectin $\left(10 \mu \mathrm{g} / \mathrm{cm}^{2}\right)$ in growth medium consisting of 40\% M199, 40\% RPMI-1640, 10\% pooled human serum (HCMV negative), 10\% Fetal Bovine Serum, heparin sodium salt (20 $\mathrm{lU} . \mathrm{ml}^{-1}$ ), ECGF (crude endothelial cell growth factor) and $50 \mu \mathrm{g} . \mathrm{ml}^{-1}$ gentamycin. The cells of passage 2-4 were used for experiments.

MVEC obtained from human foreskin, were isolated as described by van Hinsberg (Van Hinsberg, 1990). MVEC culture medium consisted of M199/RPMI 1640, 20\% pooled human serum, $10 \%$ Newborn Calf Serum, $200 \mathrm{UU} \cdot \mathrm{ml}^{-1}$ heparine sodium salt, ECGF and $50 \mu \mathrm{g} \cdot \mathrm{ml}^{-1}$ gentamycin. Cells of passage 6-10 were used in all experiments. 
HCMV strain AD169 was propagated on HEF. Cleared supernatant of HEF monolayers, displaying 90-100\% CPE was used for the experiments. VHL-E has been propagated on HUVEC and has retained it's tropism for endothelial cells. This CMV strain was isolated from a duodenal biopsy of a bone marrow transplant recipient and propagated in endothelial cells. This virus was cultured and collected as described (Waldman et al, 1989, Waldman et al., 1991). Briefly, VHL-E was applied as the total fraction of infected cultures of HUVEC, aliquoted in viral storage medium, 40\% MEM, 10\% Fetal Bovine Serum, 50\% sucrose phophate buffer (188 $\mathrm{mM}$ sucrose, $12 \mathrm{mM} \mathrm{K}_{2} \mathrm{HPO}_{4}$ and $7.5 \mathrm{mM} \mathrm{KH_{2 }} \mathrm{PO}_{4}$ ), and frozen quickly over liquid nitrogen. Both strains were quantified by plaque titration assay on HEF-monolayers.

\section{Inoculation of cells}

Confluent monolayers of HUVEC, MVEC and HEF were cultured on 24-well plates (Greiner) for the M-540 staining and on 96-well plates (Greiner) for the clotting assays. Inoculations were performed at $4^{\circ} \mathrm{C}$ or at $37^{\circ} \mathrm{C}$ at a multiplicity of infection (MOI) of 3-5. The monolayers were rinsed three times with Hank's Buffered Saline Solution (HBSS) and virus was added at $200 \mu l$.well ${ }^{-1}$ for 24 -well plates or $25 \mu$ l. well ${ }^{1}$ for 96 well plates. Before the inoculation at $4^{\circ} \mathrm{C}$, the plates were kept on ice during the HBSS washings and the addition of the virus. The plates were incubated for 90 minutes at $4^{\circ} \mathrm{C}$ or at $37^{\circ} \mathrm{C}$. For tenfold dilutions of AD169, EMEM with $2 \%$ NCS and $50 \mu \mathrm{g} / \mathrm{ml}$ gentamycin was used. VHL-E was diluted in a lysate of mock infected HUVEC in virus storage medium that had been snap-frozen through liquid nitrogen.

The mock samples used for the AD 169 experiments are EMEM with $2 \%$ NCS and for VHL-E experiments HUVEC lysate in viral storage medium.

\section{Inactivation of the virus}

Heat inactivation of the virus was performed by exposing the virus to $70^{\circ} \mathrm{C}$ for 10 minutes. UV inactivation was achieved by irradiating the virus under a germicidal lamp at $1000 \mu \mathrm{W} . \mathrm{cm}^{-2}$ for 30 minutes. Inactivation in both instances was verified by plaque titration. Inactivation by heparin (Compton et al., 1992) was achieved by incubating the virus with $200 \mu \mathrm{g} \cdot \mathrm{ml}^{-1}$ at room temperature for 5 minutes.

\section{Merocyanine-540 staining}

The merocyanine-540 (MC-540) assay was performed essentially as described before (McEvoy et al., 1986). Briefly, after the incubation with the virus, the cells were rinsed three times with RPMI 1640, after which MC-540 was added and incubated without direct light for 20 minutes. The cells were rinsed again three times 
with RPMI 1640 and the monolayers were lysed by adding $0.5 \mathrm{ml}$ penthanol. After addition of $0.5 \mathrm{ml}$ ethanol, the extinction at $550 \mathrm{~nm}$ was determined.

\section{Preparation of plasma}

Plasma was prepared as described before (Van Dam-Mieras et al., 1987). Normal plasma was obtained by pooling equal amounts of platelet-free plasma from at least 30 healthy individuals ( 15 males and 15 females not using oral contraceptive agents, average age 30 years) and stored in small amounts at $-80^{\circ} \mathrm{C}$ until use.

\section{Measurement of Cellular Procoagulant activity}

Procoagulant activity was measured on the surface of intact endothelial cell monolayers without detachment of the cells. The assay procedure used was a slight modification of the assay described before (Van Dam-Mieras; 1987). After the incubation time, the inoculum was removed and the cells were washed twice with RPMI 1640. Subsequently $200 \mu$ l of pooled normal plasma diluted $1 / 1$ with Michaelis buffer was added to each well and the cells were incubated for 15 minutes at $37^{\circ} \mathrm{C}$. After this incubation period coagulation was triggered by the addition of $100 \mu \mathrm{CaCl}_{2}$ ( $33 \mathrm{mmol} . \mathrm{r}^{-1}$ ) and the clotting time was registered.

\section{Statistical analysis}

For the statistical analysis we used the Mann-Whitney test with a $p$ value smaller than 0.001 .

\section{RESULTS.}

\section{HCMV induces membrane perturbation on MVEC}

From previous observations (Van Dam-Mieras, 1992) it was concluded that the procoagulant effect observed upon inoculation of endothelial cells with HCMV is probably the result of membrane perturbation which facilitates the interaction of coagulant factors. Given the fact that HCMV is an enveloped virus, it was hypothesised that the interaction of the viral envelope with the endothelial cell could give rise to membrane alterations. Whether these alterations are a result of viral penetration in, or fusion with cells, was the objective of this study. In these 
A

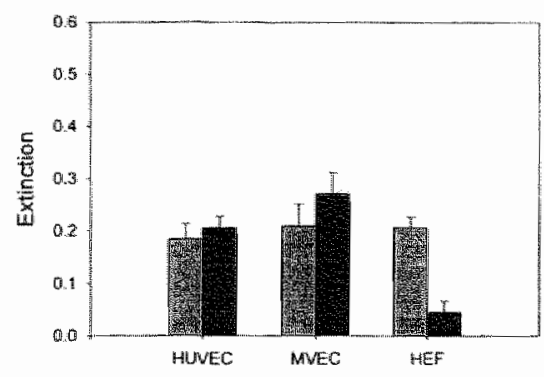

c

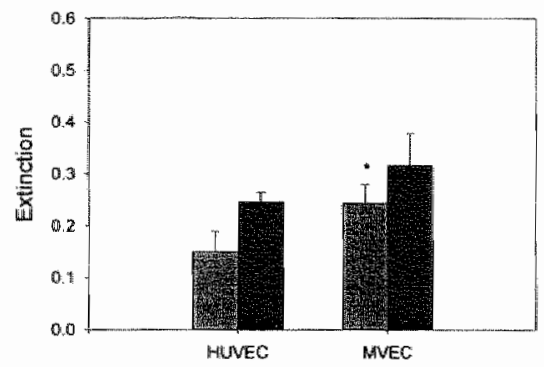

B.

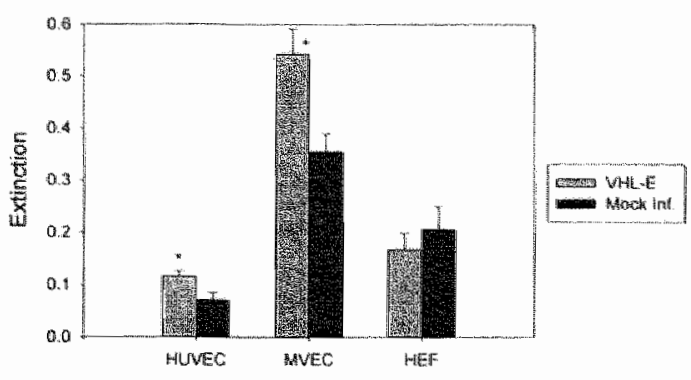

D

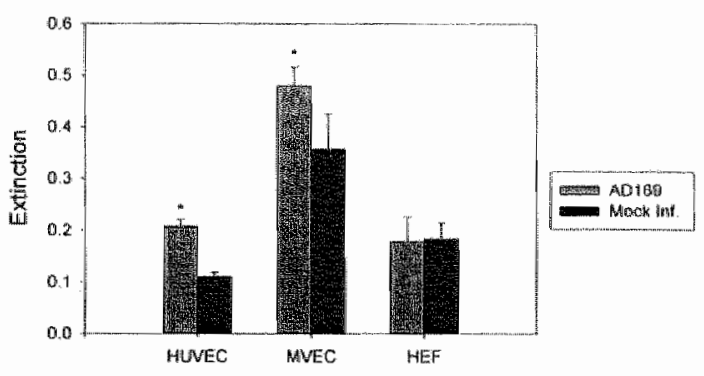

Fig. 1 Membrane perturbation of HUVEC, MVEC and HEF after inoculation of HCMV at $4^{\circ} \mathrm{C}$ and $37^{\circ} \mathrm{C}$. Cells were incubated with infectious wirus and with control inoculum as described in Materials and Methods. After incubation with MC-540, washing and lysis with penthanol, the extinction of the lysate was measured at $550 \mathrm{~nm}$. A: VHL-E at $4^{\circ} \mathrm{C}$ : B V VHL-E at $37^{\circ} \mathrm{C} ; \mathrm{C}$ : $\mathrm{AD} 169$ at $4^{\circ} \mathrm{C}$ : D: $\mathrm{AD} 169$ at $37^{\circ} \mathrm{C}$. $\mathrm{P}<0.001$ using the Mann-Whitney test for statistical analysis (Mean $\pm S D$ of 10 determinations).

experiments we compared the effects obtained with endothelial cells and fibroblasts after infection with both HCMV strains.

As it has been described that binding will take place at $4^{\circ} \mathrm{C}$, but no fusion will occur at this temperature (Comptoniet al, 1992), we subsequently compared the effects of inoculating HUVEC, MVEC and HEF with AD169 or VHL-E at $4^{\circ} \mathrm{C}$ and $37^{\circ} \mathrm{C}$.

At $4 . \mathrm{C}$ there is no significant increase in membrane perturbation observed for the two HCMV strains in the cell types used (Fig. 1A, C). At $37^{\circ} \mathrm{C}$, however, a distinct increase in MC-540 incorporation was observed in MVEC and a slighter increase in HUVEC when these cells were inoculated with HCMV of either strain (Fig. 1B. D). In HEF no significant increase in the MC-540 incorporation could be found with HCMV at $37^{\circ} \mathrm{C}$, though we know that with these cells fusion/penetration of the virus takes place within 90 minutes of incubation at $37^{\circ} \mathrm{C}$ (Compton el al., 1992). Thus we 


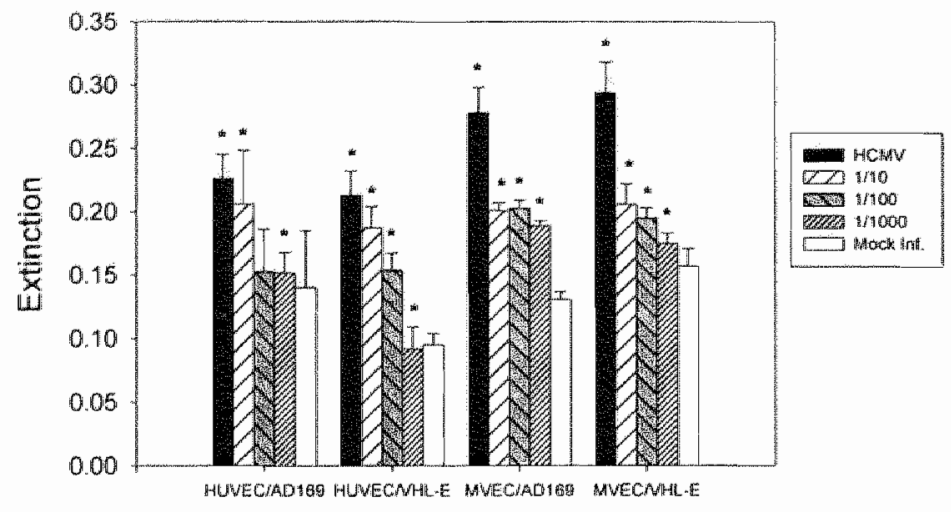

Fig. 2 Membrane perturbation dose response curve of HUVEC and MVEC at $37^{\circ} \mathrm{C}$ after inoculation with VHL-E or AD169.

After infection with different HCMV concentrations and interaction of the endothelium cells with Merocyanine 540 the extinction was measured at $550 \mathrm{~nm}$.

- PCo.001 using the Mann-Whitney tesit for statistical analysis (Mean $\pm S D$ of 10 determinations)

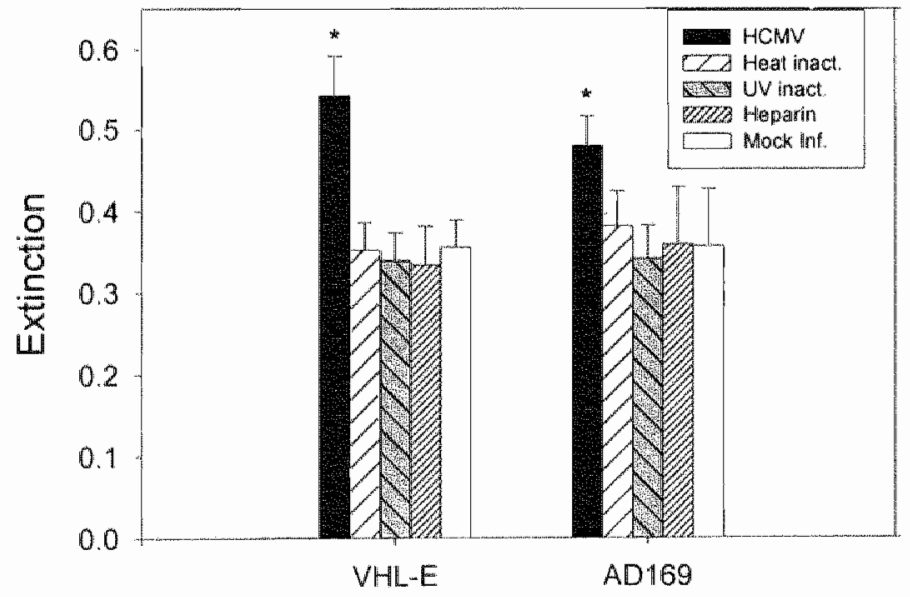

Fig. 3 Influence of neutralisation or inactivation of HCMV on the membrane perturbation of MVEC at $37^{\circ} \mathrm{C}$. The extinction was measured at $550 \mathrm{~mm}$.

* Pe 0.001 Mann-Whitney test (Mean \pm SD of 10 determinations). 
conclude that the observed effect registered through the MC-540 assay on endothelial cells at $37^{\circ} \mathrm{C}$ is most likely an endothelial cell associated event, which seems not to be caused by fusion or penetration of the virion in the cells.

In order to analyse this phenomenon we first investigated a dose response relation by comparing various concentrations of the virus in their capacity to elicit membrane perturbation. A clear dose dependent response was registered in MC-540 signal, for both virus strains (Fig. 2). Almost every virus dilution shows a significant increase in the membrane perturbation as indicated by an asterisk in Figure 2. We further investigated the virus involvement by neutralising the virus with heparin and inactivating the virus by UV and heat (Fig. 3). It appears that specific interaction between infectious virus and the endothelial cell is a prerequisite for the perturbation to occur as neutralised virus and inactivated virus preparations are unable to evoke the membrane response.

We cannot explain the discrepancy in extinction levels measured in the experiments with MVEC. It could be due to different MVEC isolates or serum batches. The eventual virus effect is, however, in all those experiments of the same magnitude.

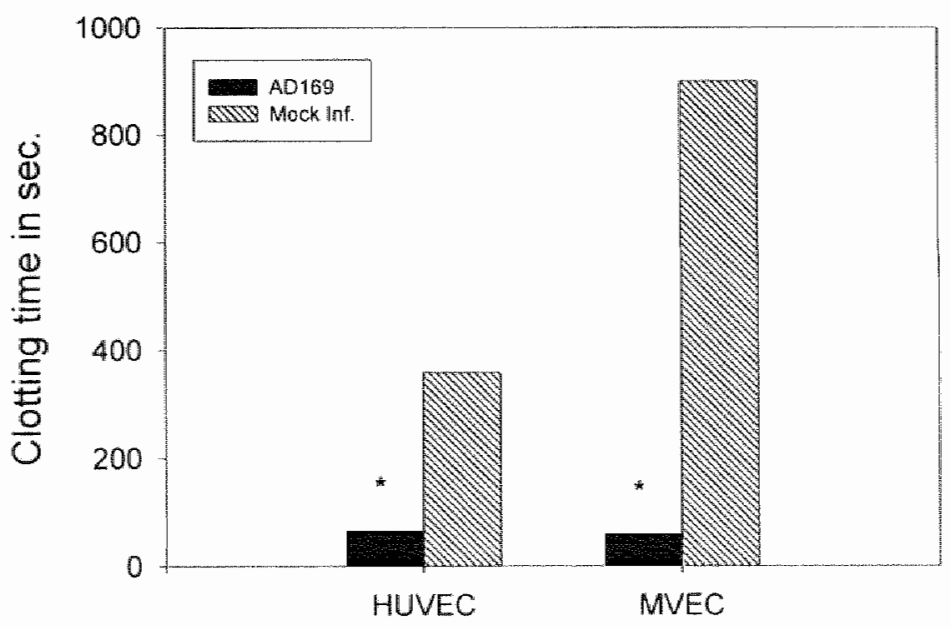

Fig. 4 The clotting time of normal plasma on HUVEC and MVEC monolayers after inoculation with AD169 and control inoculum at $37^{\circ} \mathrm{C}$.

* $P<0.001$ Mann-Whitney test (Mean $\pm S D<4$ seconds of 8 determinations) 


\section{HCMV induces an increase in procoagulant activity on MVEC}

We compared the clotting times of normal plasma on monolayers of HUVEC and MVEC, after inoculation with HCMV or mock infection (Fig. 4). Both HUVEC and MVEC displayed a significant increase in procoagulant activity after inoculation with HCMV strain AD169. HCMV induces a much larger increase in the procoagulant activity in MVEC than in HUVEC. Subsequently, the cloting times of normal plasma on monolayers of MVEC treated with different virus preparations were determined. We compared cells infected with various virus dilutions and inactivated virus samples with mock infected cells. We found a good correlation between the virus concentration and the increase in the procoagulant activity. The UV or heat inactivated virus preparation still induces an increase in the procoagulant activity compared to the mock infected cells, but the reduction in clotting time is significantly smaller in these samples compared with HCMV (Fig. 5). Therefore, it appears that the effect reported by the MC-540 signall and the increase in procoagulant activity is induced by a specific interaction of the virus particles with the endothelial cells.

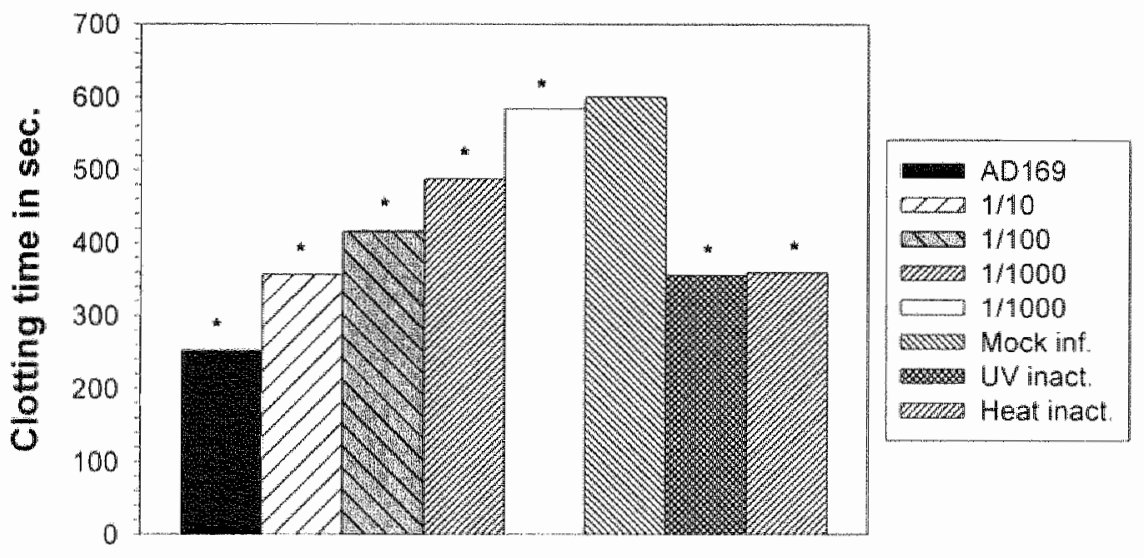

MVEC

Fig. 5 Procoaglulant activity of MVEC after AD169 infection at $37^{\circ} \mathrm{C}$ with diluted and inactivated HCMV preparations.

* $P<0.001$ Mann-Whitney test (Mean $\pm S D<20$ seconds of 8 determinations). 


\section{DISCUSSION}

CMV can contribute to vascular disease in vivo, and HCMV infection of endothelial cells, especially in the microcirculation, has been demonstrated (Banji and Salisbury, 1978, Grefte et al., 1993, Grefte et al., 1993, Myerson ef al., 1984). A number of reports have been published on the modification of endothelial cell function upon infection with HCMV (Van Dam-Mieras et all., 1987, Woodroffe et al., 1993). However, upon infection of HUVEC with laboratory strains of HCMV only a very low number of cells expresses viral proteins as detected by immunofluorescence. in these cells no cytopathological effect (CPE) can be detected and only very small amounts of HCMV can be recovered from the culture supernatant of these cells (unpubl. obs.). Such a low in vitro infection rate of course hampers in vitro studies. Several groups have reported the successful use of clinical HCMV isolates that have been passed a number of times on endothelial cultures to retain their tropism for endothelial cells (Compton and Krygrel, 1994, Waldman et al., 1989, Woodroffe et al., 1993). When using these preparations a clear CPE in infected HUVEC monolayers is apparent, while virus particles can be detected in the nucleus and cytoplasm of infected cells. (Waldman et al., 1991; own obs.).

Previous work using an animal model (Span et al, 1992, Span et al, 1993) has shown that also in the in vivo situation the amount of virus in the endothelial cells is rather low, but that in infected animals activation of endotheiial cells can be found. This suggests that, although there is no productive infection, a virus-induced phenomenon of activation of the endothellium occurs.

Infection of MVEC or HUVEC with both HCMV strains, VHL-E and AD169, induces a clear membrane perturbation in these cells, within the 90 minutes incubation. This membrane perturbation appeared only at physiological temperature and the degree of perturbation was dependent on the quantity of virus that was present in the inoculum. Furthermore, inhibition of attachment of the virus to the cells, by incubating the virus with heparin, neutralised the perturbation effect. Binding of the virions to the heparansulphate moieties of the endothelial cells therefore appears to be required for the perturbation to occur. But we realise that the virus preparations used in these experiments could also contain other factors which might be responsible for the membrane perturbation andior procoagulant activity. For instance G.D. Almeida et al. (Almeida et al., 1994) have shown that the interleukin-6 production by endothelial cells in the first 8 hours is not induced by HCMV but by a factor in the virus preparation. Because of our results such factors (if present) must be sensitive to heat, UV and heparin treatment since preincubation of the virus 
preparation precludes the membrane perturbation and part of the procoagulant activity. This phenomenon will be the goal of further studies.

In our experiments a lack of response at $4^{\circ} \mathrm{C}$, in which binding but no fusion occurs, was clearly observed (Fig. 1). This illustrates that binding alone is not sufficient to evoke a response. Furthermore, the virus has to be infectious, as inactivated preparations showed a greatly reduced MC-540 response. A remarkable aspect in these observations is the lack of perturbation signal in the fibroblasts inoculated with HCMV. From previous work we know that fibroblasts are fully permissive for HCMV and that the virus enters the fibroblast within an hour of infection, as shown by the expression of viral proteins in these cells. We therefore think that the membrane perturbation in the endothelial cells cannot simply be accounted for by the fusion with or penetration of virions in the cell. The results indicates that only an infectious virus induces a signal in endothelial cells which causes a membrane perturbation. since UV and heat inactivated virus could not induce any membrane perturbation. Also the difference between HUVEC and MVEC is remarkable. We have previously' reported similar observations using HUVEC, but the magnitude of the perturbation and procoagulant activity in HUVEC was significantly lower than the signal that was currently obtained with the microvascular cells. At present we have no explanation for the difference in mock infection between HUVEC and MVEC. As the cell number and cell viability in both preparations were similar, the difference might be due to the origin of the cells.

The dose-dependent increase in procoagulant activity that was observed 90 minutes after inoculation with the virus, is probably caused by membrane perturbation of endothelial cells. A perturbed membrane will most likely facilitate the interaction between coagulation factors by generating interaction sites on a membrane that has lost its asymmetry (Zwaal et al., 1992). In this respect it should be mentioned that in UV and heat inactivated virus preparations the virus envelope is still present which could explain the effects observed with these preparations.

The results obtained with HEF show that the virus-cell interaction per se apparently is not detected in the MC-540 incorporation assay. The question arises is what endothelial specific phenomenon is reflected by the large-scale membrane perturbation in these experiments.

As HCMV in the in vivo situation is predominantly cell-associated (Friedman, 1989) a concomitant perturbation of the endothelial cell lining of the microvasculature could contribute to prothrombotic and atherogenic events in vivo. Therefore, the "membrane response" and the specific behaviour of different cell types in this respect deserve further study. 


\section{ACKNOWLEDGMENTS}

Microvascular Endothelial Cells (MVEC), obtained from human foreskin, were generously provided by Dr. V.W.M. van Hinsbergh (IWO-TNO, Leiden). The HCMV VHL-E was a gift of Dr. W.J. Waldman (Ohio State University).

\section{REFERENCES.}

Almeida G.D., Porada C.D., St Jeor S., Ascensao J.L. (1994) Human cytomegalovirus alters interleukin-6 production by endothelial cells. Blood 15(2): $370-376$

Arbustini E., Grasso M., Diegoli M., Percivalle E., Grossi P., Bramerio M., Campana C., Goggi C., Gavazzi A., Vigano M. (1992) Histopathologic and molecular profile of human cytomegalowirus infections in patients with heart transplants. Am. J. Clin. Pathol 98: 205-13.

Banji A., Salisbury R. (1978) Cytomegalovirus and vasculitis. Br. Med. J. 1:623

Bruggeman C.A. (1993) Cytomegalovirus and latency: an overview. Virchows Arch B-cell pathology including molecular pathology 65(6): 325-333

Bruggeman C.A., Van Dam-Mieras M.C.E. (1991) The possible role of cytomegalovirus in Atherogenesis. From Melnick J.L. (Ed): Prog. Med. Virol. Basel Karger, 38: 1-26.

Bruggeman C.A., Debie W.H.M., Grauls G., van Boven C.P.A. (1986) Cytomegalovirus infection of rat endothelial cells. Arch. Virol. 87: 265-272.

Bruggeman C.A., Debie W.H.M., Muller A.D., Schutte B., Van Dam-Mieras M.C.E. (1988) Cytomegalovirus alters the von Willebrand factor content in human endothelial cells. Thromb. Haemostas. 59: 264-268.

Burgler D.R., Ford D., Vetto R.M., Hamblin A., Goldstein A., Hubbard M., Dumonde D.C. (1981) Endothelial cell presentation of antigen to human T cells. Human Immunol. 3: 209-230

Chen Y.T., Mercer G.O., Cheigh J.S., Mouradian J.A. (1992) Cytomegalovirus infection of renal allografts. Detection by polymerase chain reaction. Transplantation 53: 99-102

Compton T., Krygrel K.A. (1994) Infection of aortic endothelial cells by human cytomegalovirus. $U$. Cell Biochem. 18a (E105):266

Compton T., Nepomuceno R.R., Nowlin D. (1992) Human cytomegalovirus penetrates host cells by $\mathrm{pH}$-independent fusion at the cell surface. Virology 191: 387-395

Cotte L." Drouet E., Bissuel F., Denoyel G.A., Trepo C. (1993) Diagnostic value of amplification of human cytomegalovirus DNA from gastrointestinal biopsies from human immunodeficiency virus-infected patients. J. Clin. Microbiol 31: 2066-9.

Demmler G.J., Buffone G.J., Schimbor C.M., May R.A. (1988) Detection of cytomegalovirus in urine from newborns by using polymerase chain reaction DNA amplification. J. Irfect. Dis. 158: $1177-84$.

Fenner T.E., Garweg J., Hufert F.T. Boehnke M." Schmitz H. (1991) Diagnosis of human cytomegalovirus-induced retinitis in human immunodeficiency wirus type 1-infected subjects by using the polymerase chain feaction. J. Clin. Microbiol. 29:2621-2622.

Friedman H.M. (1989) Infection of endothelial cells by common human viruses. Rev. Infect. Dis. 11/(suppl. 4): S700-5704.

Gerna G., Zipeto D., Parea M., Revello M.G., Silini E., Percivalle E., Zavattoni M., Grossi P., Milanesi G. (1991) Monitoring of human cytomegalowirus infections and ganciclovir treatment in heart transplant recipients by determination of viremia, antigenemia, and DNAemia. J. Infect. Dis. 164: 488-98.

Gozlan J., Salord J.M., Chouaid C., Duvivier C., Picard O., Meyohas M.C., Petit J.C. (1993) Human cytomegalovirus (HCMV) late-mRNA detection in peripheral blood of AIDS patients: diagnostic value for HCMV disease compared with those of wiral culture and HCMV DNA detection. J. Clin. Microbiol 31: 1943-5.

Grefte A., Blom N., van der Giessen M., van Son W., The T.H. (1993) Ultrastructural analysis of circulating cytomegalic cells in patients with active cytomegalovirus infection: Evidence for virus production and endothelial origin. J. Inf. Dis. 168:11:10-1118. 
Grefte A., var der Giessen $M_{.,}$van son $W_{*,}$ The T.H. (1993) Circulating cytomegalowirus (CMV.) infected endothelial cells in patients with an active CMV infection. J. Infect. Dis. 167: 270277.

Hajjar D.P. (1991) Viral pathogenesis of atherosclerosis. Impact of molecular mimicry and viral genes. Am. J. Pathol 139: 1195-1211

Hendrix M.G.R., Salimans M.M.M., van Boven C.P.A., Bruggeman C.A. (1990) High prevalence of latently present cytomegalovirus in arterial walls of patients suffering from grade III atherosclerosis. Am. J. Path. 136: 23-28.

Ho W.Z., Harouse J.M., Rando R.F. Gonczol Ex, Srinivasan A., Plotkin S.A. (1990) Reciprocal enhancement of gene expression and viral replication between human cylomegalovirus and human immunadeficiency virus type 1. J. Gen. Wirol. 71 (Pt 1): 97-103.

Ho D.D., Rota T.Fi. Andrew C.A., Hirsch M.S. (1984) Replication of human cytomegalovirus in endothelial cells. J. Infect. Dis. 150: $956-957$

Jaffe E.A., Hoyer L.W., Nackman R.L. (1973) Synthesis of antihemophilic factor antigen by cultured endothelial cells. J. Clin. Inves.t 52: $2757-64$.

Kansas G.S., Ley K., Munro J.M., Tedder T.F. (1993) Regulation of leukocyte rolling and adhesion to high endothelial venules through the cytoplasmic domain of L-selectin. J. Exp. Med. 177: 833-8.

Kuijpers T.W., Roos D. (1993) Leukocyte extrawasation: mechanisms and consequences. Behring inst. Mitt. 107-37.

Liedtke W., Opalka B., Zimmermann C.W., Lignitz E. (1993) Age distribution of latent herpes simplex virus 1 and varicella-zoster virus genome in human nervous tissue. 4 . Neurol. Sci. 116: $6-11$.

Lemstrôm K.B., Bruning J.H., Bruggeman C.A., Lautenschlager I.T., Häyry P.J. (1994) Cytomegalovirus infection enhances smooth muscle cell proliferation and intimal thickening of rat aortic allografts. J. Clin. Invest. 92: 549-558.

Lemström K.B., Bruning J.H., Bruggeman C.A., Lautenschlager I.T., Hăyry P.J. (1994) Triple Drug Immunosuppression significantly Reduces Immune Activation and Allograft Arteriosclerosis in Cytomegalovirus-infected Rat Aortic Allografts and Induces Early Latency of Viral Inflection. Am. J. Pathol 144:1-14

Lo S.K., Ip K.W." Chan P.K., Nicholls J.M., Heath R.B., Shiu S.Y. (1993) Congenital infection by human cytomegalovirus with a 65 bp deletion in the morphological transforming region II. Arch. Virot 129: 295-9.

Lodge P.A., Haisch C.E., Huber S.A., Martin B., Craighead J.C. (1991) Biological differences in endothelial cells depending upon organ derivation. Transplant. Proc. 23: 216-218.

Mahalingam R., Wellish M.C., Dueland A.N., Cohrs R.J., Gilden D.H. (1992) Localization of herpes simplex wirus and varicella zoster virus DNA in human ganglia. Ann. Nourol 31: 444-8.

McEvoy L., Williamson P., Schlegel R.A. (1986) Membrane phospholipid asymmetry as a determinant of erythrocyte recognition by macrophages. Proc. Nall. Acad. Sci USA 83 $3311-3315$

Meinick J.L., Schattner $\mathrm{A}_{*}$ (1992) Viruses and atherosclerosis. Israel J. Med. Sci. 28: 463-465.

Melnick J.L., Petri B.L., Dreesman G.R., Burek J., McCollum C.H., Debakey M.E. (1983) Cytomegalovirus antigen within human arterial smooth muscle cells. Lancet 2: 644-647.

Miller G. (1990) The switch between latency and replication of Epstein-Barr wirus. J. Infect Dis. $161: 833-44$

Myerson D., Hackman R.C., Nelson J.A., McDougall J.K. (1984) Widespread presence of thistologically occult cytomegaiovirus. Hum. Pathot 15:430-438.

Nelson R.M., Dollich S., Aruffo A., Cecconi O., Bevilacqua M.P. (1993) Higher-affinity oligosaccharide ligands for E-selectin. J. Cin. Mrvest. 91; 1157-66.

Page C., Rose M., Yacoub M., Pigott R. (1992) Antigenic heterogeneity of vascular endothelium. Am. J. Pathot 141:673-683.

Roberts W.H., Sneddon J.H., Waldman J., Stephens R.E. (1989) Cytomegalowirus infection of gastrointestirval endothelium demonstrated by simultaneous nucleic acid hybridisation and immunohistochemistry. Arch. Pathol. Lab. Med. 113:461-464.

Sawtell N.M., Thompson R.L. (1992) Herpes simplex virus type 1 latency-associated transcription unit promotes anatomical site-dependent establishment and reactivation from latency. $J$. Virol. 66 : $2157-69$. 
Smith K.L., Cobain T., Dunstan R.A. (1993) Removal of cytomegalovirus DNA from donor blood by fittration. Br. J. Haematol 83: 640-2.

Spach D.H. Bauwens J.E." Myerson D., Mustafa M.M., Bowden R.A. (1993) Cytomegalowirusinduced hemorrhagic cystitis following bone marrow transplantation. C.1.D. 16;142-144.

Span A.H.M., Mullers W., Miltenburg A.M.M., Bruggeman C.A. (1991) Cylomeglalovirus reduced PMN adherence in relation to an ELAM- 1 antigen present on infected endothelial cell monolayers. Immunology 72:355-359.

Span A.H.M., van Boven C.P.A., Bruggeman C.A. (1988) The effect of cytomegalowirus infection on the adherence of pollymorphonuclear leucocytes to endothelial cells. Eur. $d$. Clin. Iirvest: $19: 542-548$.

Span A.H.M., Van Dam-Mieras M.C.E., Mullers W., Endert J., Muller A.D., Bruggeman C.A. (1991) The effect of virus infection on the adherence of leukocytes or platelets to endothelial cells. Eur. J. Clin. Invest. 21:331-338.

Span A.H.M., Grauls G., Bosman F., van Boven C.P.A., Bruggeman C.A. (4992) Cytomegalovirus infection induces vascular injury in the rat. Atherosclerosis $93: 41-52$.

Span A.H.M., Frederik P.M., Grauls G., van Boven C.P.A., Bruggeman C.A. (1993) CNV induced vascular Injury: an electron-microscopic study in the rat. In vivo $7: 567-574$.

Tenser R.B., Edris W.A., Hay K.A. (1993) Neuronal control of herpes simplex virus latency. Virolagy 195: $337-47$

Van Dam-Mieras M.C.E., Bruggeman C.A., Mulller A.D., Deble W.H.M., Zwaal R.F.A. (1987) Induction of endothelial cell procoagulant activity by cytamegalowirus infection. Thromb. Res. 47: $69-75$.

Van Dam-Mieras M.C.E., Muller A.D., van Hinsbergh V.W.M., Mullers W.J.H.A., Bomans P.H.H., Bruggeman C.A. (1992) The procoagulant response of cytomegalovirus infected endothelial cells. Thromb. Haemostasis 68(3): $364-370$.

Van Hins berg V.W.M. (1990) Macro,- and microvascular endothelial cells from human tissue. Piper H.M. Editor. Cell culture techniques in heart and vessel research. Springer-Verlag BerlinHeidelberg. 178-204.

Wagner C.R., Vetto R.M., Burger D.R. (1984) The mechanissms of antigen presentation by endothelial cells. Immunobiol. 168: 453-469.

Waldman W.J., Sneddon J.M., Stephens R.E., Roberts W.H. (1989) Enhanced endotheliall cytopathogenicity induced by a cytomegalowirus strain propagated in endothelial cells. 4 . Med. Virol. 28: 223-230.

Waldman W.J., Roberts W.H., Davis D.H., Williams M.V., Sedmak D.D., Stephens R.E. (1991) Preservation of natural endothelial cytopathagenicity of cytomegalovirus by propagation in endothelial cells. Arch. Wirol. 117: 143-64.

Weber B., Klinghardt U., Lux A., Braun W., Rabenau H., Doerr H.W. (1993) Detection of neutralizing antibodies against human cytomegalovirus: influemce of strain variation. I. Mod. Virol 40: 28-34.

Woodroffe S.B., Garnett H.M., Danis V.A. (1993) Interleukin-1 production and cell-activation response to cytomegalowirus infection of vascular endothellal cells. Arch. Wirol 133295-308

Zwaal R.F.A., Comfurius P., Bevers E.M. (1992) Platelet procoagulant activity and microvesicle formation. Its putative role in hemostasis and thrombosis. Biochim. Biophys. Acta 1180: 1-8. 


\section{ENDOTHELIAL RESPONSES TO HCMV INFECTION IN THE CONTEXT OF VASCULAR PATHOLOGY}

M.E.P. Slobbe-van Drunen, R.C.R.M. Vossen, A.D. Muller, G. Grauls, M.C.E. van Dam-Mieras and C.A. Bruggeman 


\section{SUMMARY}

Infection of endothelial cells by human cytomegalovirus (HCMV) induces various cellular responses like membrane perturbation, procoagulant activity and production of growth factors and cytokines. In this study we investigated whether these responses are induced directly by the virus or indirectly through as yet unknown mediators.

It was found that both the membrane perturbation and the procoagulant activity observed during HCMV infection of human umbilical vein endothelial cells can be induced by the virus as well as the supernatant of the virus preparation used. The nature of the factors responsible for these phenomena during HCMV infection is not known, but it was shown that various cytokines like IL-1, TNF and IL-8 are capable of inducing these effects in endothelial cells. This indicates that cytokines present in the virus preparations are likely candidates.

In addition, the induction of chemokine production by HCMV infection was studied in human umbilical vein endothelial cells. In endothelial cells IL-8 production was enhanced, but RANTES and MCP-1 release was not. Chemokines play an important role in inflammatory responses like activation and trafficking of leukocytes to inflammatory sites. Since infiltration of monocytes and lymphocytes is frequently observed in the presence of HCMV-infected endothelial cells, our present results once more underline the possibility that HCMV may contribute to vascular disease mediated by its inflammatory and procoagulant effects on endothelial cells. 


\section{INTRODUCTION}

Human cytomegalovirus (HCMV) infections are common and usually asymptomatic in persons with a mature, competent immune system and remain latent after primary infection. Cell types such as bone marrow progenitor cells, neutrophils, monocytes, lymphocytes as well as endothelial cells are sites for acute or latent HCMV infections (Prösch et al., 1998, Sinzger et al., 1995). Under immunosuppressed conditions, such as in transplant recipients and patients with AIDS, reactivation of latent virus frequently occurs (Jacobson and Mills, 1988, Winggard et al., 1988). In these patients CMV can cause leukocytopenia, impairment of graft functioning, pneumonia, retinitis and other symptoms (Ho, 1991, Jacobson and Mills, 1988, Gangan 1994, Winston et al., 1987). These acute symptoms are associated with active HCMV infection. Besides this, there are indications that HCMV is also involved in arteriosclerosis after solid organ transplantation. In these situations the levell of infectious virus is very low (Pouteil-Noble et al., 1993).

Transplant-associated arteriosclerosis is characterised by persistent vascular inflammation. During this process adhesion and infiltration of leukocytes into the subendothelium is observed (Pober and Cotran, 1990. Tanaka et al., 1994). Although the mechanism is not clear there is some evidence that immune inflammatory cells are important for this process. The process seems to be mediated mainly by the infiltration of T-cells ( $\mathrm{Li}$ et al., 1996). The development of arteriosclerosis can be accelerated by CMV infection in the recipient. Such an acceleration could be mediated by CMV through the expression of cell adhesion molecules and production of chemokines. Because it has been documented before that $C M V$ infections induce the expression of adhesion molecules like intercellular cell adhesion molecule-1 (ICAM-1), vascular cell adhesion molecule-1 (VCAM-1) and E-selectin on endothelial cells (Tanaka et al. "1994, Bruggeman and van DamMieras, 1991, Span et al., 1991a, Span et al., 1991b).

Chemokines are structurally related polypeptides that are important for activation and trafficking of leukocytes to inflammatory sites (Baggliolini et al., 1994). Chemokines form four subfamilies defined by the relative position of the first cystein tandem, $\mathrm{CXC}, \mathrm{CC}, \mathrm{C}$ and $\mathrm{CX}_{3} \mathrm{C}$. The $\mathrm{CXC}(\alpha)$ chemokines attract neutrophils, whereas the $C C(\beta)$ chemokines attract monocytes, eosinophils, basophils and lymphocytes. The potent chemoattractant interleukin 8 (IL-8), a member of the $\alpha$ chemokine family, is predominantly chemotactic for neutrophils and and has been shown to play an important role in inflammatory responses. It is produced by different cell types such as epithelial cells, fibroblasts, neutrophils, monocytes, macrophages and endothelial cells. RANTES (Regulated upon Activation, Normal T- 
cell. Expressed and Secreted), chemotactic for T-cell and monocytes, and monocyte chemoattractant protein (MCP-1), chemotactic for monocytes, belong to the $\beta$ chemokine family. There are indications that both RANTES and MCP-1 play a role in allograft rejections (Pattison et al., 1994, Nadeau et al., 1995)

From the perspective of the involvement of an inflammatory component in transplant rejection, the interaction of CMV with cells of the vascular wall, and more specifically that with endothelial cells, is interesting. Endothelial cells form an interface between vasculature and tissue and are involved in vital processes like the immune response, leukocyte traffic, platelet activation, coagulation and fibrinolysis. The infection of endothelial cells with HCMV has been described to induce membrane perturbation and procoagulant activity (van Geelen et al., 1995) and this could contribute to the induction of haemostatic dysfunction and thrombotic events accompanying atherosclerotic disease. Whether these effects are directly caused by HCMV infection or more indirectly via adhesion and stimulation of leukocytes following the induction of adhesion molecules and cytokines by HCMV, is not known.

In this study we show that HCMV induces membrane perturbation and procoagulant activity in human umbilical vein endothelial cells (HUVEC) in an indirect way. probably via the release of soluble factors induced by HCMV infection.

\section{METHODS}

\section{Virus culture}

HCMV strain AD169 was propagated in human embryonal fibroblasts (HEF) in Earl's Modified Eagle Medium (ICN, Zoetermeer, The Netherlands), supplemented with $2 \%$ (v/v) foetal calf serum (Integro, Zaandam, The Netherlands). The supernatants of the human embryonal fibroblasts (HEF) monolayers, displaying $90-100 \%$ cytopathic effect, were stored at $-70^{\circ} \mathrm{C}$. Virus titre was analysed by a plaque titration assay in HEF.

\section{Endothelial cell culture}

HUVEC were isolated from umbilical cords as previously described (Slobbe van Drunen et al. . 1997). The cells were propagated in wells coated with fibronectin, and grown in a medium consisting of $40 \%$ (V/V) M199 (Gibco. Breda, The Netherlands), 40\% (v/v) RPMl-1640 (Gibco), 20\% (v/v) Newborn Calf Serum (NCS; PAN system, Germany) $20 \mathrm{U} / \mathrm{ml}$ heparin sodium salt (ICN), $2 \mathrm{ml} / /$ bovine brain extract, $200 \mathrm{mM} \mathrm{L}$ glutamine (Serva, Heidelberg, Germany) and $50 \mu \mathrm{g} / \mathrm{ml}$ gentamycin (AUV. Cuyk, The 
Netherlands). All experiments were performed with cells of passages 2-6. For the infection experiments described below, the HUVEC were cultured on 96well plates (Costar, Badhoevedorp, The Netherlands).

\section{Infection}

HUVEC were cultured on 24-well plates (Greiner, Frickenhausen "Germany) for merocyanine-540 (M-540) staining and on 96-well plates (Greiner) for clotting assay and chemokine experiments. The confluent monolayers were rinsed with phosphatebuffered saline (PBS, $0.14 \mathrm{M} \mathrm{NaCl}, 3 \mathrm{mM} \mathrm{KCl}, 6.5 \mathrm{mM} \mathrm{Na} 2 \mathrm{HPO}_{4}$ and $1.5 \mathrm{mM}$ $\mathrm{KH}_{2} \mathrm{PO}_{4} \mathrm{pH} \mathrm{7.2)}$ and preincubated with IMDM supplemented with $15 \%$ (V/V) NCS, $200 \mathrm{mM}$ L-glutamine and $50 \mu \mathrm{g} / \mathrm{ml}$ gentamycin ( $15 \%$ IMDM) for $1-4$ hours at $37^{\circ} \mathrm{C}$. Virus dilutions or dilutions of the supernatant of virus pools which had been ultracentrifuged (90 min. at $7000 \mathrm{~g}$ ) were made in IMDM supplemented with $2 \%(\mathrm{~V} / \mathrm{v}$ ) NCS, $200 \mathrm{mM} \mathrm{L-glutamine} \mathrm{and} 50 \mu \mathrm{g} / \mathrm{ml}$ gentamycin ( $2 \%$ IMDM). The plates were incubated for 90 minutes at $37^{\circ} \mathrm{C}$. The control samples used for clotting assay and MC-540 staining is EMEM with $2 \%$ NCS which had been incubated for 10 days with HEF. The cytokines used in the experiments were diluted in $2 \%$ IMDM. The plates were incubated for 90 minutes at $37^{\circ} \mathrm{C}$. In the experiments where the chemokine release is measured the cells are incubated with HUVEC medium without heparin sodium salt and bovine brain extract after the infection with HCMV.

\section{Measurement of membrane perturbation}

The measurement of the membrane perturbation was performed by using Merocyanine-540 (MC-540) staining essentially as described by McEvoy (McEvoy et al. 1986). Briefly, after the incubation with the virus, the supernatant or with cytokines, the cells were rinsed three times with RPMI 1640, after which MC-540 was added and incubated in the dark for 20 minutes. The cells were rinsed again three times with RPMI 1640 and the monolayers were lysed by adding $0.5 \mathrm{ml}$ penthanol. After addition of $0.5 \mathrm{ml}$ ethanol, the extinction at $550 \mathrm{~nm}$ was determined.

\section{Measurement of cellular procoagulant activity}

Procoagulant activity was measured on the surface of intact endothelial cell monolayers without detachment of the cells. The assay procedure used was a slight modification of the assay described before (Van Dam-Mieras et al., 1987). After the infection time, the inoculum was removed and the cells were washed wice with RPMI 1640. Subsequently $200 \mu 1$ pooled normal plasma diluted $1 / 1$ with Michaelis 
buffer was added to each well and the cells were incubated for 15 minutes at $37^{\circ} \mathrm{C}$. After this incubation period coagulation was triggered by the addition of $100 \mu \mathrm{I} \mathrm{CaCl}_{2}$ ( $33 \mathrm{mmol}^{-1}$ ) and the clotting time was registered. As a positive control incubation with thrombin $2 \mathrm{U} / \mathrm{ml}$ diluted in $2 \%$ IMDM was performed.

\section{Chemokine assay}

The release of IL-8 was measured in the supernatants of HUVEC using an enzyme linked immunosorbent assays (ELISA). 96-Well immuno maxisorp plates (Nunc Inc., Roskilde. Denmark) were coated overnight at $4^{\circ} \mathrm{C}$ with an $\mathrm{IL}-8$ specific murine monoclonal antibody HM5 (lgG1). Test samples were added in duplicate and incubated for $2 \mathrm{hr}$ at room temperature. The biotinylated rabbit anti-human IL-8 antibodies were incubated at room temperature for $1 \mathrm{hr}$, followed by a $1 \mathrm{hr}$ incubation with peroxidase-labeled streptavidin (DAKO). Finally, 3,3:5, $5^{\prime}$ tetramethylbenzidine (Kirkegaard and Perry, Gaithersberg, MD) was added as substrate. The results were standardised against human recombinant IL-8 (range $2.5 \mathrm{pg} / \mathrm{ml}$ to $5 \mathrm{ng} / \mathrm{ml}$ ). The monoclonal antibodies and the recombinant IL-8 were kindly provided by Dr. W.A Buurman (Department of Surgery, University of Maastricht, The Netherlands).

\section{Detection of viral antigen by immunofluorescence staining}

HUVEC were fixed with methanol at room temperature for $10 \mathrm{~min}$. The cells were incubated with the E13 monoclonal antibody (Biosoft, Varilhes, France), in a dilution of $1 / 100$ in $0.1 \%$ BSA/PBS for $45 \mathrm{~min}$, followed by incubation with a FITC-labelled rabbit anti-mouse antibody (DAKO, diluted $1 / 80$ in $0.1 \%$ BSA/PBS) for $45 \mathrm{~min}$. The E13 antibody recognises the $76 \mathrm{kDa}$ nuclear HCMV immediate-early antigen. Nuclei were subsequently stained with $0.5 \mathrm{ng} / \mathrm{ml}$ 4',6-diamino-2-phenyl indole (DAPI) in PBS containing 2.3\% (w/v) 1,4-di-azobicyclo-(2,2,2)-octane (DAPCO). The degree of infection was determined by counting the number of FITC-positive cells as well as the total number of nuciei in three different wells ( 4 microscopic fields per well).

\section{Statistical analysis}

For the statistical analysis we used the Mann-Whitney test with a $p$ value smaller than 0.001 . 


\section{A.}

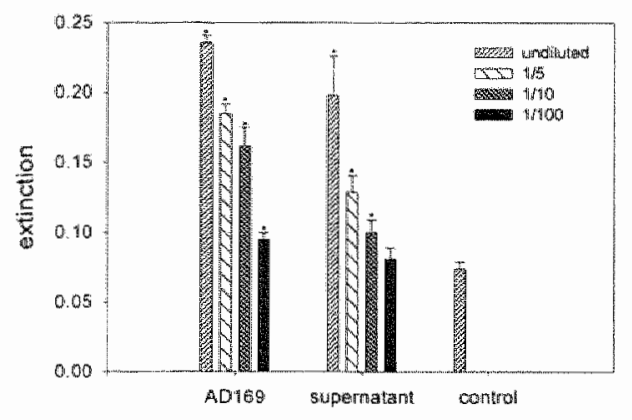

B

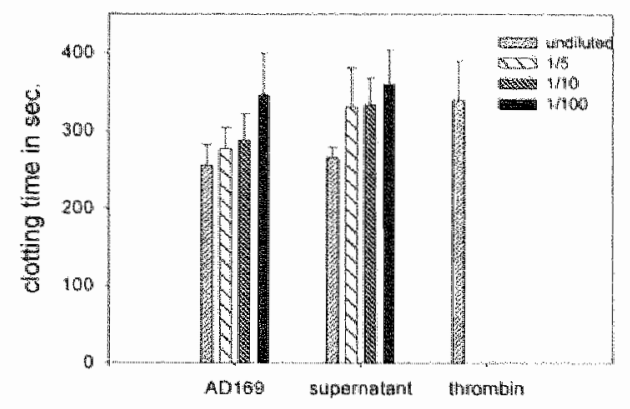

Fig.1 Membrane perturbation and procoagulant activity of HUVEC after incubation with HCMV.

After incubation with AD169 or the supernatant, the membrane perturbation was measured by using the interaction of MC540 with endothelial cell membranes (A). The procoagulant activity was measured 90 min after incubation with AD169 or supernatant (B). The control for the procaagulant activity was $>10 \mathrm{~min}$. " Data are significantly different from control.

\section{RESULTS}

\section{Membrane perturbation and procoagulant activity}

To investigate whether the induced membrane perturbation and procoagulant activity in HCMV infected HUVEC is caused by the virus particles per se or by additional (unknown) factors in the HCMV preparations used, the virus preparation was submitted to ultracentrifugation and subsequently both the untreated virus preparation and the supernatant were used for our experiments. In these experiments the virus inoculum and the supernatant of the ultracentrifuged virus inoculum were compared to a control preparation consisting of $2 \%$ EMEM which had been incubated with uninfected HEF. This control was chosen because the virus preparation is produced in HEF. The results show that the supernatant of the virus inoculum induces a concentration dependent effect on membrane perturbation, which is very similar to that found with the virus inoculum (Fig. 1A). Both the supernatant and the virus inoculum induce a membrane perturbation significantly different from the control. The control preparation gave a much lower membrane perturbation level, identical to that of $2 \%$ EMEM that had not been in contact with HEF (results not shown). Also the procoagulant activity induced by the supernatant was comparable to that of the virus inoculum (Fig $1 \mathrm{~B}$ ). The clotting times induced by both virus inoculum and supernatant are significantly lower than that of the control medium (procoagulant activity $>10 \mathrm{~min}$ ). 
A

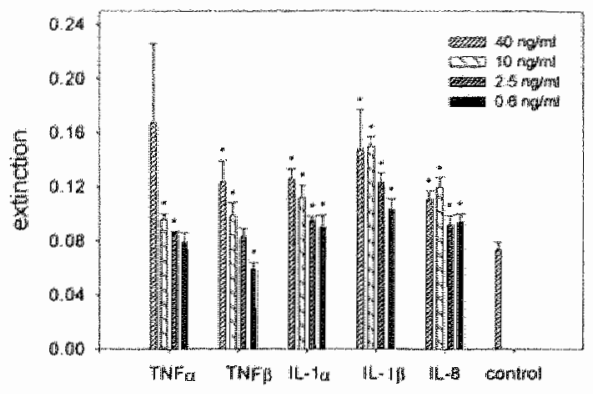

B

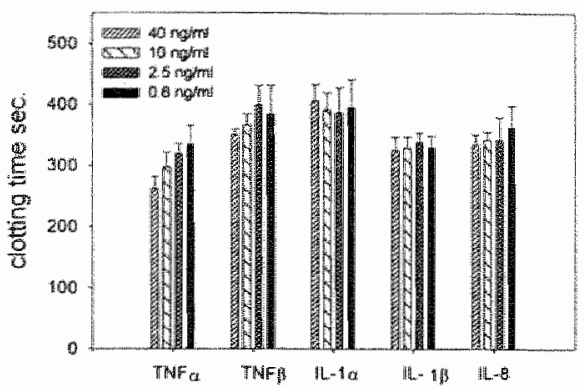

Fig.2 Influence of cytokines on membrane perturbation and procoagulant activity of HUVEC. HUVEC were incubated with various cytokines at different concentration and the membrane perturbation (A) and procoagulant activity (B) were measured. The control for the procoagulant activity was $>10$ min." Data are significantlly different from control.

These results indicate that the supernatant of infected HEF contains one or more agents able to induce membrane perturbation and procoagulant activity. The productive infection level of HCMV in HUVEC does not seem to be important for the observed effects since incubation of HUVEC with the supernatant did not result in HCMV immediate early (IE) positive cells, whereas it induced a similar membrane perturbation and procoagulant response as the virus preparation which did result in HCMV IE positive cells. Therefore, it was speculated that factors like cytokines might be involved in the induction of membrane perturbation and/or procoagulant activity. For this purpose HUVEC were incubated with different concentrations of TNF $\alpha$, TNF $\beta, I L-1 \alpha, I L-1 \beta$ and $I L-8$ and the effect on membrane perturbation and procoagulant activity was investigated. The results show that all these cytokines can induce both effects (Fig. 2). This indicates that cytokines, produced by HCMV infected fibroblasts, and therefore present in the virus preparation, might be responsible for the induced membrane perturbation and procoagulant activity. The level of the cytokines $I L-\|$ and TNF was not increased in our virus preperation (results not shown) indicating that factors, such as lipids or other cytokines that were not investigated in the present study, could be involved.

\section{Chemokine release}

Previous results from our lab and the results from Craigen and Michelson (Craigen et al., 1997, Michelson et al., 1997) showed that HCMV-infected fibroblasts release chemokines like IL-8 and RANTES. This release was not inhibited by antibodies against $\mathrm{L}-1$ and TNF indicating that the release of IL- 8 and RANTES was not 


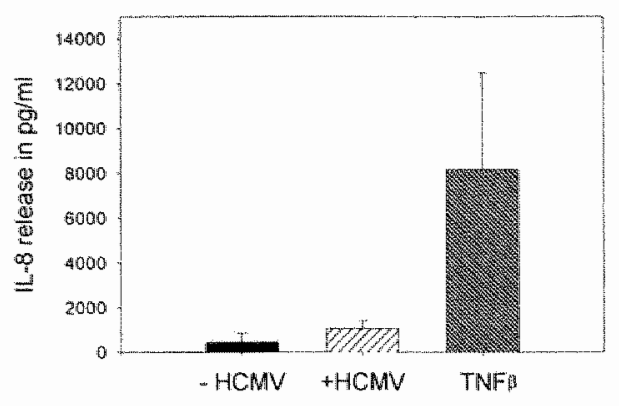

Fig.3 Influence of AD169 on the IL-8 release of HUVEC.

HUVEC were infected with AD169 for 1 hour and the medium was replaced by culture medium. The amount of IL $\times 8$ was measured 24 hours after infection in the culture medium of the cells.

induced by IL-1 and TNF. To investigate whether HCMV infection in HUVEC induces the release of chemokines, HUVEC monolayers were infected with the HCMV strain AD169 and the release of IL-8, RANTES and MCP-1 was measured. IL-8 release was measured in the culture medium 24 hours after HCMV infection. As a positive control TNF $\beta$, a compound known to trigger IL-8 release, was used. The IL-8 release by HCMV was $1053 \mathrm{pg} / \mathrm{ml}$ (Fig.3). The release of IL-8 in the culture

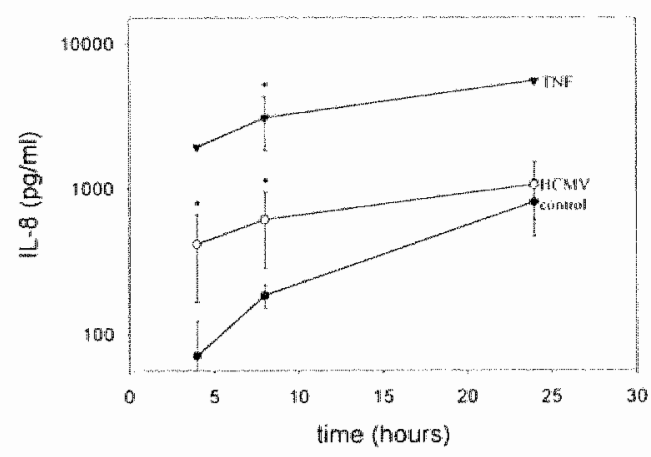

Fig. 4 Time response curve of $I L-8$ release of HCMV infected HUVEC.

At 1 hour after infection the cells were washed and incubated in HUVEC medium without heparin and growth factor. At the indicated times the 1 - 8 release was measured in the culture medium. "Data are significamtly different from control. 
medium of uninfected cell (-HCMV) was $461 \mathrm{pg} / \mathrm{ml}$. The amount of IL-8 release upon incubation with and without HCMV is much lower than that induced by TNF $\beta$.

To investigate whether the L-8 release was caused by virus entry or by events later in the viral life cycle, the $\mathrm{L}-8$ release was measured at 4,8 and $24 \mathrm{~h}$ after infection. As can be seen in Figure 4, an uninfected HUVEC monolayer secretes small amounts of $1 \mathrm{~L}-8$ into the culture medium. Infection of the HUVEC monolayer with HCMV leads to increased IL-8 secretion at 4-8 hours after infection, while at 24 hours post infection the difference in IL-8 release between infected and control cells disappeared. The amount of 1 L-8 release in TNFP-stimulated HUVEC was greater than that of control cells and HCMV infected HUVEC at all time points measured. Thus, the incubation of endothelial cell monolayers with HCMV results in an increased $1 L-8$ secretion in the first 8 hours after infection. The release of RANTES and MCP-1 was measured 0 to 72 hours after infection. However no effect of the HCMV infection of HUVEC on the release of RANTES or MCP-1 was detected (results not shown).

We wondered if an increase in IL-8 production would interfere with the HCMV infection process. Therefore the effect of IL-8 on the virus infection. measured by the IE antigen expression and virus production was determined. IL-8 was added to the HUVEC monolayer 24 hours or 1 hour prior to HCMV infection or 4 hours post infection. As can be seen in Figure 5 , the addition of $\| L-8$ had no influence on $\mathbb{E}$ expression. In addition, no effect on virus production was found (results not shown).

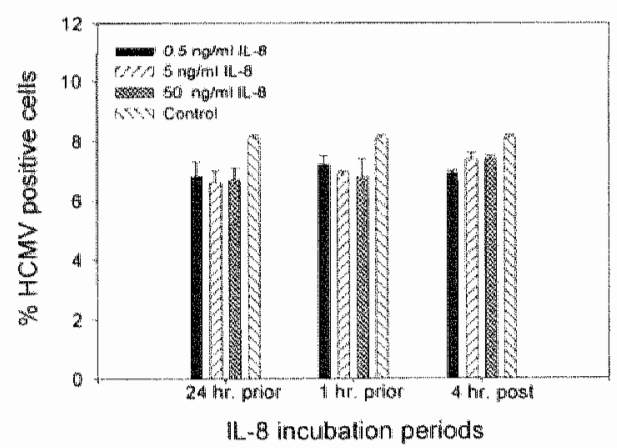

Fig.5 Influence of IL-8 on the expression of HCMV IE antigen.

HUVEC were incubated with different IL-8 concentrations 24 hours and 1 hour prior to infection and 4 hours post infection. The cells were fixed 24 hours after infection with methanol and the HCMV IE protein was detected by immunohislochemistry 


\section{DISCUSSION}

Previous results of our group have shown that HCMV induces membrane perturbation and procoagulant activity in endothelial cells (van Geelen et al. 1995). In this study it was shown that the HCMV induced procoagulant activity and membrane perturbation can also be induced by the supernatant of the virus preparation. This indicates that soluble factors induced by HCMV are able to induce these responses. From the literature it is known that cells infected with HCMV produce all kinds of factors like growth factors and cytokines (Michelson et al., 1994, Craigen et al., 1997, Michelson et al., 1997). As the virus preparation used for the infection experiments is prepared by propagation of the virus in fibroblasts, it can be expected that this virus preparation contains various factors in addition to HCMV. which may be responsible for the effects reported in this study. It was hypothesised that the membrane perturbation and/or the procoagulant activity could be induced by cytokines present in the supernatant of HCMV infected cells. The present results demonstrate that indeed the cytokines used in this study. TNF, IL-1 and IL-8, were capable of inducing these responses. The cytokines TNF and IL-1 seem not to be invalved in the effects obtained in our infection experiments since the virus preperations did not contain elevated levels of these cytokines. Till now it is unclear which factors are responsible for the induced membrane perturbation and procoagulant activity wherefore further analysis is necessary

Chemokines are involved in attracting neutrophils, monocytes and lymphocytes. Cytokine production may thus be involved in the increased adherence of polymorphonuclear leukocytes (PMN) and monocytes (MC) to an HCMV infected monolayer of HUVEC as previously observed. Span et al (Span et al., 1991a, Span et al., 1991b) reported that the increased adherence of PMNS after HCMV infection could be explained by the expression of adhesion molecules like ICAM and ELAM, but also the release of chemokines could play a role.

In vivo studies indicate that HCMV is involved in transplant associated arteriosclerosis, a process characterised by persistent vascular inflammation. The inflammatory processes is characterised by an increased infiltration of inflammatory cells like monocytes, macrophages, neutrophils, and $T$ lymphocytes, probably mediated by the expression of adhesion molecules and chemokines. In vivo studies have shown that cytokines and chemokines play an important role in allograft rejection (Hayashi et al. 1995, Nadeau et al., 1995). For example, elevated plasma IL-8 levels were observed in patients suffering from acute allograft rejection with HCMV (Fietze et al, 1994), while Monti et al. (Monti et al., 1996) found elevated RANTES concentrations in the bronchoalveolar lavage fluids in lung transplant 
patients with rejection or CMV pneumonitis. It was demonstrated that macrophages were the main source for RANTES. The chemokine MCP-1 was reported to be increased in the cerebrospinal fluid of AIDS patients with cytomegalovirus encephalitis (Bernasconi et al., 1996). Also in vitro studies lend support to a role for cytokines in HCMV induced pathology. Infection of fibroblasts with AD169 results in a rapid induction of RANTES, while no RANTES induction was found in other cell types like promyelocytic cell line TF-11, U937 cells and U373 astrocytoma cells (Michelson et al., 1997). It was also shown that an endothelial cell adapted HCMV strain, which had a higher infection rate for endotheliall cells than AD169, induces a release of IL-8 (Grundy et al., In Press). Also our present results point to an increase in IL-8 production by endothelial cells upon infection with HCMV, but no release of RANTES or MCP- $\uparrow$ was detected.

This increase in the $1 \mathrm{~L}-8$ release could contribute to the previously detected increase in the adherence of PMN and MC on HCMV infected HUVEC (Span et al., 1991a; Span et al., 1991b). It should be kept in mind, however, that HUVEC is not very permissive for the virus strain AD169 and that the infection level is never above $10 \%$. Therefore only a limited portion of the monolayer may be expected to actually contribute to IL-8 production. On the other hand, the production of cytokines by only a small amount of the cells in the intimal layer of the blood vessels could still have an important consequence for the inflammatory process in wivo. The results reported by Waldman confirm this (Waldman and Knight, 1996). In his model it is shown that HCMV infected endothelial cells are able to activate T-cells from seropositive donors. These activated T-cells produce interferon and tumour necrosis factor which in turn can have an impact on endothelial cells. TNF- $\beta$, like other stimuli, induces the IL-8 production in endothelial cells (Rot et al., 1996, Hoch et al., 1996, Mantovani et al., 1997. Bratt and Palmblad, 1997). In vivo it can be expected that through the interaction / communication of different cell types the effect of HCMV on the production of chemokines by endothelial cells is enhanced.

Our present results once more underline the interesting role of endothelial cells in HCMV induced vascular pathology. Endothelial cells are not highly permissive for HCMV strain AD169 but once infected a range of effects which all can contribute to an inflammatory response is observed. The infection of endothelial cells by HCMV leads to a release of cytokines and chemokines, an increased expression of adhesion molecules, adhesion of PMNs and an increased membrane perturbation and procoagulant activity. 


\section{REFERENCES}

Baggliolini, M., DeWald, B. and Moser, B. (1994) Interleukin-B and related chemotactic cytokines: CXC and CC chemokines. Adw. Immunol. $55: 97-179$

Bernasconi, S., Clinque, P., Peri, G., Sozzani, S., Crociati, A., Torri, W., Vicenzil, E., Vago, L., Lazzarin, A, Poli, G. and Mantovani, A. (1996) Selective elevation of monocyte chemotactic protein-1 in the cerebrospinal fluid of AIDS patients with cytomegalovirus encephalitis. If Inf Dis. 174: 1098-1101

Bratt, J. and Palmblad . J. (1997) Cytokine-induced neutrophil-mediated injury of human endothelial cells. J. Immunol. 159: $912-918$

Bruggeman, C.A. and wan Dam-Mieras, M.C.E. (1991) The passible role of cytomegalovirus in atherogenesis. Prog. Med. Virol. 38: 1-26

Craigen, J.L., Yong, K.L., Jordan, N.J., Maccormac, L.P., Westwick, J. and Akabar, A.N. (1997) Human cytomegalowirus infection up-regulates interleukin-8 gene expression and stimulates meutrophill transendothelial migration. Immunology 92: 138-145

Fietze, E., Prosch, S., Reinke, P., Stein, J., Döcke, W.-D., Staffa, G., Löning, S., Devaux, S., Emmrich, F., von Baehr, R., Krüger, D.H. and Volk, H.-D. (1994) Cytomegalovirus infection in transplant recipients. Transplantation 58: 675-680

Grundy, J.E., Lawson, K., MacCormac, L.P., Fletcher, J.M. and Yong, K.L. (In Press) Cytomegalovirus infected endothelial cells recruit neutrophils by the secretion of C-X-C chemokines and transmit virus direct neutrophi-endothelial cell contact and during neutrophil transendothelial migration

Hayashi, M., Martinez, O.M., Garcia-Kennedey, R., So, S., Esquivel, C.O. and Krams, S.M. (1995) Expression of cytokines and immune mediators during chronic liver allograft rejection. Transplantation 60: 1533-1538

Ho, M. (1991) Human cytomegalovirus infections in immunosuppressed patients. In: Cytomegalovirus: biology and infection. New York: Plenum Medical Book Company., 249-300

Hoch, R.C., Schraufstätter, I.U. and Cochrane, C.G. (1996) In vivo, in vitro, and molecular aspects of interleukin-8 and interleukin-8 receptors. J. Lab. Clim. Med. 128(2): 134-145

Jacobson, M.A. and Mills, J. (1988) Serious cytomegalovirus disease in the acquired immunodeficiency syndrome (AIDS). Ann. Intern. Med. 108: 585-549

Li, F.L., Grauls, G., Yin, M. and Bruggeman, C.A. (1996) Correlation between the intensity of cytamegalovirus infection and the amount of perivasculitis in aortic allograft. Transplant. Int. 9: $\$ 340-5344$

Mantovani, A., Sozzani, S., Vecchi, A., Introna, M. and Allavena, P. (1997) Cytokine activation of endothelial cells: new molecules for an old paradigm. Thrombosis and Haemostasis 78(1): $406-414$

McEvoy, L., Williamson, P. and Schlegel, R.A. (1986) Membrane phospholipid asymmetry as a determinant of erythrocyte recognition by macrophages. Proc. Natl. Acad. Sci USA 83: $3311-3315$

Michelson, S., Alcami, J., Kim, S.J., Danielpour, D., Bacholerie, F., Picard, L. Bessia, C., Paya, C. and Virelizier, J.L. (1994) Human cytomegalowirus infection induces transcription and secretion of transforming growth factor beta. U. Virology 68: $5730-5737$

Michelson, S., Dal Monte, P., Zipeto, D., Bodaghi, B., Laurent, L., Oberlin, E., Arenzana* Seisdledos, F., Virelizier, J.-L. and Landini, M.P. (1997) Modulation of RANTES production by human cytomegalovirus infection of fibroblasts. Whol. 71: 6495-6500

Monti, G., Magnan, A., Fattal, M., Rain, B., Humbert, M., Mege, J.-L., Noirclerc, M., Dartevelle, P., Cerrina, J., Simonneau, $G_{*}$ Galanaud, P. and Emilie, D. (1996) Intrapulmonary production of RANTES during rejection and CMV pneumonitis after lung transplantation. Transplantation 61: $1757-1762$

Nadeau, K.C., Azuma, H. and Tilney, N.L. (1995) Sequential cytokine dyramics in chronic rejection of rat renal allografts: Rolle for cytokines RANTES and MCP-1. Proc. Natl. Acad. SCI USA 92. $8729-8733$

Pattison, J., Nelson, P.J., Huie, P., Leuttichau, I., Farshid, G., Sibley, R.K. andi Kromsky, A.M. (1994) Rantes chemokine expression in cell-mediated transplant rejection of the kidney. Lancet 343: 209-211 
Pober, J.S. and Cotran, R.S. (1990) The role of endothelial cells in infiammation. Transplantation 50 , 537.544

Pouteil-Noble, C., Ecochard, R., Landrivon, G., Donia-Maged, A., Tardy, J.C., Bosshard, S., Colon, S., Betuel, H. Aymard, M. and Touraine, J.L. (1993) Cytomegalovirus intection-an etiological factor for rejection? A prospective study in 242 renal transplant patients. Transplantation 55(4): $651-7$

Prösch, S., Volk, H.-D., Reinke, P., Ploch, K., Döcke, W.-D. and Kruger, D.H. (1998) Human cytomegalovirus infection in transplantrecipients: role of TNF-alpha for reactivation and replication of human cytomegalovirus. Cintl, a jr (editor). In: CMV-related Immunopathology. 21. $29-41$

Rot, A., Hub, E., Middleton, J., Pons, F., Rabeck, C., Thierer, K., Wintle, J., Wolf, B., Zsak, M. and Dukor, P. (1996) Some aspects of IL-8 pathophysiology III. chemokine interaction with endothellai cells. J. Leukocyte Biology 59: $39-44$

Sinzger, C., Grefte, A., Plachter, B., Gouw, A.S.H., Hauw The, T. and Jahn, G. (1995) Fibroblasts, epithelial cells, endothelial cells and smooth muscle cells are major targets of human cytomegalowirus infection in lung and gastrointestinal tissues. J. Gen. Wirol 76: 741-750

Slobbe van Drunen, M.E.P., Vossen, R.C.R.M., Couwenberg, F.M.D., Hulsbosch, M.M., Heemskerk, J.W.M., van Dam-Mieras, M.C.E. and Bruggeman, C.A. (1997) Activation of protein kinase $C$ enhances the infection of endothelial cells by human cytomegalowirus. Virus Res. 48: 207-213

Span, A.H., Mullers, W., Miltenburg, A.M. and Bruggeman, C.A. (1991a) Cytomegalovirus induced PMM adherence in relation to an ELAM-1 antigen present on infected endothelial cell monolayers. Immunology 72(3): 355 60

Span, A.H., van Dam Mieras, M.C., Mullers, W., Endert, $J_{w}$ Muller, A.D. and Bruggeman, C.A. (1991b) The effect of virus infection on the adherence of leukocytes or platelets to endotheliall cells. Eur. J Clin. Invest. 21(3): 331-8

Tanaka, H., Sukhova, G.K., Swanson, S.J., Cybulsky, M.l., Schoen, F.J. and Libby, P. (1994) Endothelial and smooth muscle cells express leukocyte adhesion molecules heterageneously during acute rejection of rabbit cardiac allografts. Am. S. Pathol. 144(5): $938 \mathrm{i}-1$

Van Dam-Mieras, M.C.E., Bruggman, C.A., Muller, A.D., Debie, W.H.M. and Zwaal, R.F.A. (1987) Induction of endothelial cell procoagulant activity by cytomegalovirus infection. Thromb. Res. 47: $69-75$

Van Geelen, A.G." Slobbe van Drunen, M.E., Muller, A.D., Bruggeman, C.A. and Van Dam Mieras, M.C. (1995) Membrane related effects in endothelial cells induced by human cytomegalovirus. Anch. Virol. 140(9):1601-12

Waldman, W.J. and Knight, D.A. (1996) Cytokine-mediated induction of endothelial adhesion molecule and histocompatibility leukocyte antigem expression by activated cytomegallowirusactivated T cells. Am. J Pathol 148: 105-119

Winggard, J.R., Chen, D.H., Burns, W.H., Fuller, D.J., Braine, H.G., Yeager, A.M., Kaiser, H., Burke, P.J. Graham, M.L., Santos, G.W. and Saral, R. (1988) Cytomegalowirus infections after autologous bone marrow transplantation with comparison to infection after allogeneic bone marrow transplantation. Blood 71 : 1432

Winston, D.J., Ho, W.G. and Lin, C.H. (1987) Intravenous immunoglobulin for prevention of cytomegalovirus infection and interstitial pneumonia after bone marrow transplantation. Ann. intern. Med 106: 12-18 


\section{ACTIVATION OF PROTEIN KINASE C ENHANCES THE INFECTION OF ENDOTHELIAL CELLS BY HUMAN CYTOMEGALOVIRUS}

Marlea E.P. Slobbe-van Drunen, Renée C.R.M. Vossen, Franka M.D. Couwenberg, Martine M. Hulsbosch, Johan W.M. Heemskerk, Maria C.E. van Dam-Mieras, and Cathrien A. Bruggeman 


\section{SUMMARY}

The infection of cultured endothelial cells with human cytomegalovirus (HCMV) is generally limited to less than $10 \%$ of the cells in contrast to HCMV infection of fibroblasts, where essentially all cells can be infected. It is known that HCMV infection influences a number of signal transduction pathways of infected cells. We therefore questioned whether, conversely, the infectivity of human umbilical vein endothelial cells could be influenced by the deliberate activation of these pathways. When endothelial cells were treated prior to infection with phorbol myristoyl acetate, an activator of protein kinase $C$, the number of HCMV-positive cells increased 2-3 fold. On the other hand, pre-treatment of the cells with Ro $31-8220$, a specific protein kinase $\mathrm{C}$ inhibitor, or with staurosporine, a general protein kinase inhibitor, resulted in a decreased infection level and in abolishment of the PMA-induced effect. Pre-treatment with the protein phosphatase inhibitor, okadaic acid, caused a slight increase in infectivity, whereas pre-treatment with the protein tyrosine kinase inhibitor, genistein, was without effect. Furthermore, neither forskolin and ilomedine, compounds known to activate the endothelial adenylate cyclase, nor the calcium ionophore A23187 were able to influence HCMV infectivity. It is concluded that, a) the HCMV infection level of unstimulated endothelial cells is influenced by the basal level of protein kinase $C_{\text {, }}$ and $b$ ) stimulation of protein kinase $C$ prior to infection results in an increase of infection by HCMV. 


\section{INTRODUCTION}

Cytomegalovirus (CMV), a herpesvirus, induces subclinical infection in healthy individuals, pneumonitis in immunocompromised adults and a range of congenital malformations in new-borns (Ho et al., 1991; Stagno et al. 1982). In addition, there is increasing evidence that a number of diseases of the vascular system, like transplantation associated atherosclerosis and restenosis, coincide with human cytomegalovirus (HCMV) infection (Melnick et al., 1992; Speir et al., 1994; Vercelloti, 1995). Since the vascular endothelium is known to be involved in the immune response, the possible role of HCMV in stimulating this response has been proposed some years ago (Bruggeman et al., 1991). Evidence for this hypothesis comes mainly from in vitro experiments with cultured endothelial cells, in which HCMV infection results in an increased expression of the adhesion molecules ICAM-1 and E-selectin (Bruggeman et al., 1991), and an increased adherence of granulocytes and monocytes to the endothelium (Span et al., 1991). Other experiments with endothelial and other cells have shown that infection with HCMV leads to the production of growth factors and cytokines (Michelson et al., 1994; Woodroffe et al., 1993).

Because of their localisation at the tissue/blood interface endothelial cells have a strategic position with respect to the interaction with circulating cells. In vitro studies with endothelial cells indicate that only approximately ten percent of the cells in a monolayer can be infected, as detected by immunological staining of viral proteins (Friedman et al., 1981; Ho et al., 1984). This contrasts to experiments with cultured fibroblasts and smooth muscle cells, where essentially all celis can be infected under similar conditions. Apparently the endothelium functions as a barrier for CMV infection, although there are indications that the infectivity can be affected by the activation state of the cells (Vossen et al, in press).

Therefore the intima must not be seen as an inert barrier but as a barrier whose function can be modulated for example by contact with other cells and cytokines. In the translation of such extracellular events to cellular responses signal transduction pathways are involved. Consequently, we therefore were interested to know if stimulation of signal transduction pathways influences the degree of HCMV infection of endothelial cells. To study this, we treated human umbilical vein endothelial cells (HUVEC) with a number of modulators known to influence specific intracellular pathways and, subsequently, determined the effects of these pre-treatments on HCMV infection. From the results we concluded that prior activation of PKC induces a considerable increase in HCMV infection of endothelial cells. 


\section{MATERIAL AND METHODS}

\section{Virus culture}

HCMV strain AD169 was propagated in human embryonal fibroblasts in Earl's Modified Eagle Medium (ICN, Zoetermeer, The Netherlands), supplemented with $2 \%$ (v/v) foetal calf serum (Integro, Zaandam, The Netherlands). The cleared supernatants of the fibroblast monolayers, displaying $90-100 \%$ cytopathic effect, were stored at $-70^{\circ} \mathrm{C}$. Virus titre was analysed by a plaque titration assay in human embryonal fibroblasts.

\section{Endothelial cell culture}

HUVEC were isolated from umbilical cords as previously described (Jaffe et al. 1973). The cells were propagated in wells coated with fibronectin, and grown in a medium consisting of $40 \%$ (v/v) M199 (Gibco, Breda, The Netherlands), 40\% (v/v) RPMI-1640 (Gibco), 20\% (v/v) foetal calf serum, $20 \mathrm{U} / \mathrm{ml}$ heparin sodium salt (ICN), $2 \mathrm{ml} / \mathrm{l}$ bovine brain extract (Ho et al., 1984), $200 \mathrm{mM}$ L-glutamine (Serva, Heidelberg, Germany) and $50 \mu \mathrm{g} / \mathrm{ml}$ gentamycin (AUV, Cuyk, The Netherlands). All experiments were performed with cells of passages 2-6. For the infection experiments, described below, the HUVEC were cultured on 96-well plates (Costar, Badhoevedorp, The Netherlands).

\section{Infection}

Cells grown to confluency on 96-well plates were washed with phosphate-buffered saline (PBS, $0.14 \mathrm{M} \mathrm{NaCl} 3 \mathrm{mM} \mathrm{KCl}, 6.5 \mathrm{mM} \mathrm{Na}_{2} \mathrm{HPO}_{4}$ and $1.5 \mathrm{mM} \mathrm{KH} \mathrm{MO}_{4} \mathrm{pH}$ 7.2) and incubated in infection medium, which was composed of $85 \%$ (V/V) IMDM (Iscove's Modified Dulbecco's Medium, Gibco) supplemented with 15\% (v/v) foetal calf serum, $200 \mathrm{mM} \mathrm{L}$-glutamine and $50 \mu \mathrm{g} / \mathrm{ml}$ gentamycin at $37^{\circ} \mathrm{C}$ for $4 \mathrm{hr}$. The cells were pre-stimulated as indicated in the results section, grown in infection medium during 1 or 24 hr, washed with PBS, and subsequently incubated with HCMV (MOI 2) in infection medium for $1 \mathrm{~h}$. In a number of experiments, the cells were pre-treated with a modifying compound for $15 \mathrm{~min}$, and subsequently incubated with this compound in the presence or absence of phorbol myristoyl acetate (PMA) for $1 \mathrm{hr}$. 


\section{Detection of viral antigen by immunofluorescence staining}

Twenty-four hours after infection, culture medium was removed and HUVEC were fixed with methanol at room temperature for $10 \mathrm{~min}$. The cells were then preincubated with $0.1 \%(w / v)$ bovine serum albumin (BSA) in PBS and incubated with the E13 monoclonal antibody (Biosoft, Varilhes, France, in a dilution of $1 / 100$ in

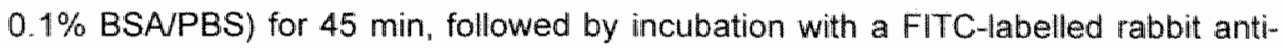
mouse antibody (DAKO, diluted $1 / 80$ in $0.1 \%$ BSA/PBS) for $45 \mathrm{~min}$. The E13 antibody recognises the $76 \mathrm{kDa}$ nuclear HCMV immediate-early antigen. Nuclei were subsequently stained with $0.5 \mathrm{ng} / \mathrm{ml}$ 4,6-diamino-2-phenyl indole (DAPI) in PBS containing $2.3 \%(w / v) 1,4$-di-azobicyclo- $(2,2,2)$-octane (DAPCO). The degree of infection was determined by counting the number of FITC-positive cells as well as the total number of nuclei in three different wells (four microscopic fields per well).

\section{Chemicals}

Specific modulators that were used are: phorbol myristoyl acetate (PMA), staurosporine, genistein, okadaic acid, forskolin, serotonin and calcium ionophore $A$ 23187, which were all purchased from Sigma (Bornem, Belgium). In addition, Ro 318220 which was obtained from Biomol (Plymouth Meeting, PA, U.S.A.) and ilomedine (ZK-36374) from Schering (Weesp, The Netherlands).

Table 1. The influence of the chemicals used in the experiments on signal transduction.

\begin{tabular}{|c|c|}
\hline Chemical & Effect \\
\hline PMA & Protein kinase stimulator \\
\hline Staurosporine & Protein kinase inhibitor \\
\hline Ro $31-8220$ & Protein kinase C inhibitor (Davis et al. 1989, Dieter et al. 1991) \\
\hline Okadaic acid & $\begin{array}{l}\text { Protein serine and threonine phosphatase } 1 \text { and } 2 \text { a inhibitor (Cohen et al, } \\
1990 \text { ) }\end{array}$ \\
\hline Genestein & Protein tyrosine kinase inhibitor (Akiyama et al. 1987) \\
\hline Forskolin & Direct activator of adenyllate cyclase (Legrand et al. 1989) \\
\hline Homedine & Indirect activator of adenylate cyclase (Heller et al. 1991) \\
\hline Serotonin & Inhibitor of adenylate cyclase (Vanhoutte et al. 1990) \\
\hline
\end{tabular}




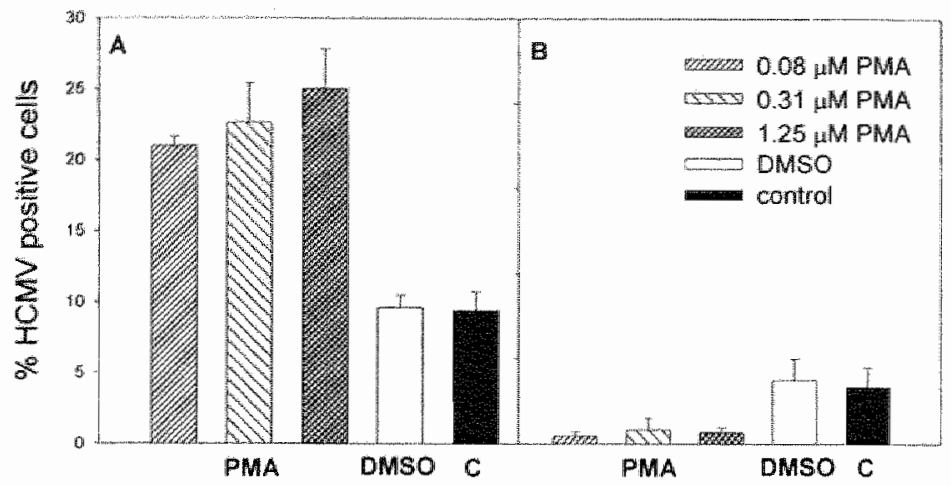

Figi. 1 Effect of PMA on HCMV infectivity of endothelial cells.

HUVEC were preincubated with 0.08-1.25 $\mu$ M PMA, $0.125 \%(w / w)$ DMSO vehicle or infection medium (control, C) during $1 \mathrm{~h}(\mathrm{~A})$ or $24 \mathrm{~h}(\mathrm{~B})$. The cells were then infected with $\mathrm{AD} 169$ (MOI 2) and the degree of infection was determined $24 \mathrm{~h}$ later by immunofluorescence. Data are mean values $\pm S D(n=3)$ from one experiment, representative of four so performed.

\section{Results}

\section{Effects of PMA on HCMV infection}

To study the effect of PKC activation on HCMV infection, confluent monolayers of HUVEC were treated with the specific PKC activator PMA (Sharkey et al., 1985). HUVEC were preincubated with various PMA concentrations for $1 \mathrm{hr}$. The number of HCMV-positive cells was increased by about 2-3 times already with 80 nM PMA, whereas the DMSO vehicle was without influence (Fig. 1A). When HUVEC were preincubated with the same concentrations of PMA for period of $24 \mathrm{hr}$, during which the PKC activity of these cells is known to be down-regulated (Heller et al., 1991), HCMV infectivity was almost completely suppressed (Fig. 1B). The prolonged treatment with PMA influenced not only the infectibility of the endothelial cells, but also their morphological structure. The normal cobble-stone appearance of HUVEC changed into a structure with elongated cells after incubation with PMA (results not shown). 


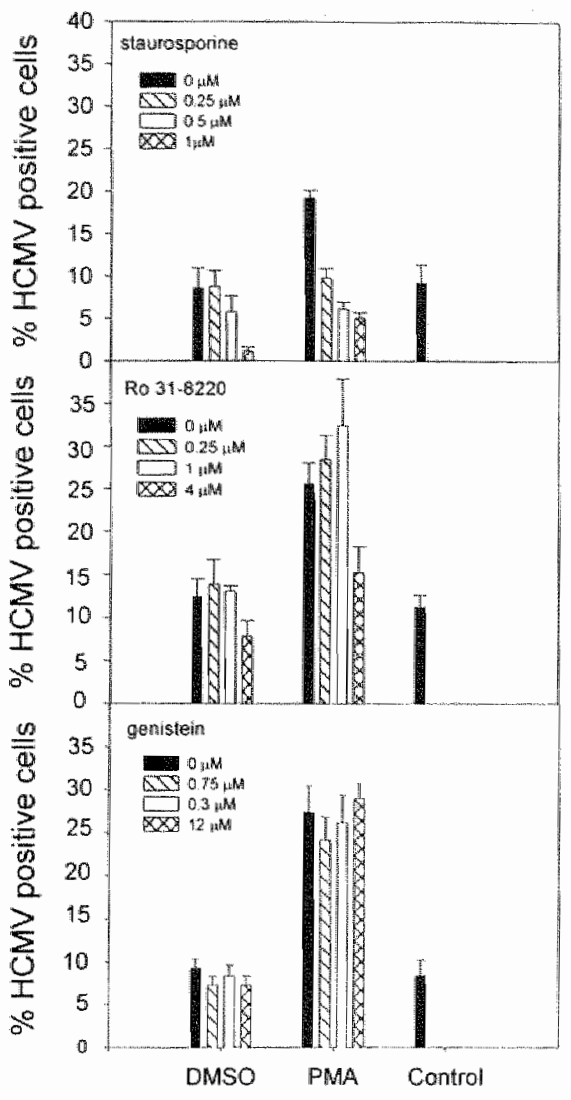

Fig. 2 Effect of warious protein kinase inhibitors on HCMV infectivity.

Endothellal cells were preincubated with $0-1 \mu M$ staurosporine $(A), 0-4 \mu R 031-8220$ (B), or 0 . $12 \mu \mathrm{M}$ genistein (C) for $15 \mathrm{~min}$. Subsequently, the cells were incubated with $0.125 \%$ ( $\mathrm{v} / \mathrm{V}$ ) DMSO vehicle, $1.25 \mu \mathrm{M}$ PMA or infection medium (control) for $1 \mathrm{~h}$ and then infected with AD169 (MOI 2). The number of infected endothelial cells was quantified $24 \mathrm{~h}$ later by immunofluorescence. Data are mean values $\pm S . D,(n=3)$ of one experiment, representative of three experiments.

\section{Effects of various protein kinase inhibitors on HCMV infection}

We designed a number of experiments to confirm and elaborate the suggestion that activation of PKC has a stimulatory effect on HCMV infection. For this purpose, HUVEC were treated with a number of protein kinase inhibitors for $15 \mathrm{~min}$, and subsequently incubated for $1 \mathrm{hr}$ with $1.25 \mu \mathrm{M}$ PMA or $0.25 \%(\mathrm{v} / \mathrm{v})$ DMSO vehicle in combination with the inhibitor. To investiglate whether protein kinases other than PKC might be involved as well, we compared the effects of various concentrations of 
staurosporine, a general protein kinase inhibitor, of Ro 31-8220, a specific protein kinase $C$ inhibitor (Davis et al., 1989; Dieter et al., 1991), and of genistein, a specific protein tyrosine kinase inhibitor (Akiyama et al., 1987). Pre-treatment of the HUVEC with micromolar concentrations of staurosporine (Fig. 2A) or $4 \mu \mathrm{M}$ Ro 31-8220 (Fig. $2 \mathrm{~B}$ ) for $1 \mathrm{~h}$ resulted in a considerable reduction in the number of HCMV-positive cells in unstimulated as well as PMA stimulated cells. Ro 31-8220 did not inhibit but seemed to increase the number of positive cells when concentrations of 0.25 and 1 $\mu M$ were used but this stimulation was not significant. Endothelial cells were not viable at higher Ro 31-8220 concentrations, so the influence of higher concentrations of Ro 31-8220 on HCMV could not be investigated. In contrast, genistein treatment did not affect the infection level (Fig. 2C). These findings again suggest that the activity of $\mathrm{PKC}_{1}$ which is a serine/threonine protein kinase, and not that of tyrosine kinases, is a modulating factor for HCMV infectivity.

\section{Effects of okadaic acid on HCMV infection}

Okadaic acid is a potent inhibitor of protein serine and threonine phosphatases 1 and $2 \mathrm{~A}$ (Cohen et al., 1990), often with effects similar to that of protein kinase activation. The number of HCMV-positive cells was $4.95 \pm 1.61$ (mean $\pm \mathrm{SD}_{n} \mathrm{n}=3$ ) in the presence of $0.25 \%$ DMSO (unstimulated cells) and $21.51 \pm 1.11$ (mean \pm SD, $n=3$ ) in the presence of $1.25 \mu M$ PMA. Okadaic acid had no significant influence on unstimulated cells (with $50 \mathrm{~nm}$ okadaic acid the number of positive cells was $6.73 \pm$ 0.76 (mean $\pm S D, n=3$ ). The amount of HCMV IE antigen positive cells increased to $30.64 \pm 0.64$ (mean $\pm S D, n=3$ ) in the presence of $50 \mathrm{nM}$ okadaic acid in PMA stimulated cells. Therefore, inhibition of protein serine and threonine phosphatases 1 and $2 \mathrm{~A}$ seems to induce an increase of HCMV positive cells in PMA treated cells.

\section{Effects of forskolin, ilomedine and serotonin on HCMV infectivity}

Another important signal transduction pathway known to be influenced by HCMV infection is that involving the adenylate cyclase-mediated generation of CAMP (Albrecht et al. 1991). Whether, conversely, modulation of adenylate cyclase may also influence HCMV infectivity was studied by using three chemicals: a) forskolin, which directly activates adenylate cyclase, thus increasing the level of CAMP (Legrand et al. 1989); b) the prostacyclin analogue ilomedine, which activates adenylate cyclase indirectly (Heller et al., 1991); c) serotonin, which inhibits adenylate cyclase through a $\mathrm{G}_{\text {; }}$-protein coupled receptor (Vanhoutte et al., 1990). As shown in Table 2, none of these components were able to change the number of HCMV-positive cells. 
Table 2: Effects of Forskolin, ilomedine and serotonin on HCMV infectivity."

\begin{tabular}{|c|ccccc|}
\hline & \multicolumn{5}{|c|}{ Number of infected cells (\%) } \\
\hline Concentration & $\mathbf{0} \mu \mathrm{M}$ & $\mathbf{0 . 1 3} \boldsymbol{M} \mathbf{M}$ & $\mathbf{0 . 5} \mu \mathbf{M}$ & $\mathbf{2} \mu \mathbf{M}$ & $\mathbf{8} \mu \mathbf{M}$ \\
\hline Forskolin & $4.9 \pm 0.4$ & $6.3 \pm 0.3$ & $6.3 \pm 0.2$ & $6.1 \pm 0.1$ & $5.0 \pm 0.6$ \\
Serotonin & $9.2 \pm 2.4$ & $9.5 \pm 1.0$ & $8.0 \pm 1.1$ & $7.7 \pm 0.7$ & $8.8 \pm 1.0$ \\
\hline Concentration & $\mathbf{0 ~} \mathbf{n M}$ & $\mathbf{6 2 . 5} \mathbf{n M}$ & $\mathbf{1 2 5} \mathbf{n M}$ & $\mathbf{2 5 0} \mathbf{n M}$ & $\mathbf{5 0 0} \mathbf{n M}$ \\
\hline llomedine & $9.4 \pm 1.3$ & $12.8 \pm 0.8$ & $13.3 \pm 1.0$ & $11.8 \pm 1.1$ & $9.8 \pm 1.9$ \\
\hline
\end{tabular}

* Endothelial cells were preincubated with $0-8 \mu \mathrm{M}$ forskolin, $0-500 \mathrm{mM}$ ilomedine or $0-8 \mu \mathrm{M}$ serotonin during $1 \mathrm{~h}$. The cells were then infected with AD169 (MOI 2), and the dlegree of infection was determined $24 \mathrm{hr}$ later by immunofluorescence. Data are mean walues $\pm S D(n=3)$ from one experiment, representative of four so performed.

\section{Effect of $\mathbf{A 2 3 1 8 7}$ on HCMV infectivity}

We also investigated the possible influence of elevation of the cytosolic calcium concentration by using the calcium ionophore A23187. The infection level of the endothelial cells in absence of $A 23187$ was $9.6 \% \pm 0.5$ (mean $\pm S D, n=3$ ) and $10.6 \%$ \pm 0.6 (mean $\pm \mathrm{SD}, \mathrm{n}=3$ ) in the presence of $2.5 \mu \mathrm{M}$ A23187, a relatively low dose but sufficient to raise the intracellular free calcium concentration to submicromolar levels. Apparently, A23187 treatment did not influence HCMV infection in HUVEC.

\section{DISCUSSION}

Endothelial cells show a low permissiveness for CMV indicating that these cells have a barrier function for the virus (Vossen et al., in press). We wondered if the barrier function of endothelial cells is influenced by the activation state of the cells. As signal transduction pathways are involved in the regulation of cellular functions, we investigated whether activation or inhibition of specific signal transduction pathways affects the HCMV infection of endothelial cells.

The results indicate that HUVEC have a basal, low PKC activity required for HCMV infection. Stimulation of this PKC activity (by short term treatment with PMA or by using protein phosphatase inhibitors) appears to facilitate HCMV infection, whereas conversely, inhibition of PKC (by prolonged treatment with PMA or with serine/threonine protein kinase inhibitors) decreases the infection dramatically. Modulation of tyrosine kinases (by using the specific tyrosine kinase inhibitor genistein) and adenylate cyclase (by using the adenylate cyclase modulators 
forskolin, ilomedine and serotonin' does not influence HCMV infection in endothellal cells. It is shown in this paper that the infection level of HUVEC with HCMV can be considerably increased, from approximately $10 \%$ up to $35 \%$ of the cells in the monolayer, by activation of the PKC pathway. Nevertheless, PKC modulation did not result in complete infection of all endothelial cells, suggesting that also other yet unknown factors play a crucial role in the protection of endothelial cells against HCMV infection. There are several ways in which endothelial cells can protect themselves against infection: a) a low expression of HCMV receptors, required for binding or fusion of the virus with the cell membrane; b) a low rate of viral protein production and replication; c) the possibility that infected endothelial cells can release factors which protect neighbouring endothelial cells for infection.

The precise mechanism by which PKC facilitates HCMV infection of endothelial cells. remains to be elucidated. Before the cells are infected the virus has to conquer different steps in the infection process. First the virus has to bind and penetrate the cells. The next step is the transport of viral DNA to the nucleus were transcription and replication should take place. The final step is the assembly of structural proteins, the packaging of viral DNA in the nucleus and the migration of the nucleocapsid to the cell surface. In the experiments described here CMV infection of endothelial cells was detected by the expression of a HCMV IE antigen within the cells. Using this technique it was shown that PKC influences the CMV infection in endothelial cells suggesting that PKC influences the first two steps of the infection process. Experiments are now in progress to study the binding and internalisation of HCMV in endothelial cells and the influence of PKC in this process.

It is known from the literature that PKC influences the first step of infection of other viruses such as Epstein-Barr virus, humar iimmunodeficiency virus, mouse mammary tumour virus and murine ectropic leukaemia virus. (Aquino et al., 1993; Petersen et al, 1992; Bolander, 1994; Yoshimoto et al. 1992). PKC can have stimulating as well as inhibiting effects on virus infection. It induces the phosphorylation of the CR2 receptor of lymphoid cells and a concomitant increase of the fusion of Epstein-Barr wirus with the cell membrane (Aquino et al., 1993). On the other hand if the receptors for human immunodeficiency virus (Petersen et al., 1992) or mouse mammary tumour virus (Bolander "1994) are phosphorylated the viral infectivity is reduced by the internalisation of the receptor.

In addition to the finding that PKC has an influence on HCMV infection as described in this study, other investigators have found that the infection of HCMV influences specific signal transduction systems in fibroblasts, since second messengers such as cyclic adenosine 3;, -monophosphate (cAMP) (Albrecht et al., 1991), inositol 1,4,5-trisphosphate, diacylglycerol and $\mathrm{Ca}^{2+}$ appeared to be elevated shortly after 
infection (Nokta et al., 1987; Valyi-Nagy et al. 1988). This indicates that HCMV itself has also an effect on the PKC activity. We conclude from our present study that not only HCMV can influence the PKC activity but that vice versa PKC activity has also a profound impact on HCMV infection of endothelial cells.

\section{REFERENCES}

Akiyama, T., Ishida, J., Nakagawa, S., Ogawara, H., Watanabo, S-l., Itoh, N., Shibuya, M., and Fukami,Y. (1987) Genistein, a specific inhibitor of tyrosine-specific protein kinase. J. Biol. Chem. 262:5592-5595

Albrecht, T., Fons, M.P., Boldogh, I., AbuBakar, S., Deng, C.Z., and Millonoff, D. (1991) Metabolic and cellular effects of human cytomegalowirus infection. Transplantation Proc. 23:48-55

Aquino, A., Lisi, A., Pozzi, D., Ravagnan, G., and Grimaldi, S. (1993) EBV membrane receptor (CR2) is phosphorylated by protein kinase $C$ (PKC) in the early stages of virus entry into ymphablatoid cells line (Raji). Biochem. Biophys. Res Commun. 196794-802

Bolander, F.F. (1994) Regulation of the mouse mammary tumor virus receptor by phosphorylation and internalization in the mammary epithelial cells. J. Cell. Physiol. 161:124-128

Bruggeman, C.A., and Van Dam-Mieras, M.C.E. (1991) The possible role of cytomegalovirus in atherogenesis. Prog. Med. Wirol 38:1-26

Cohen, P., Holmes, C.F.B., and Tsuktani, Y. (1990) Okadaic acid: a new probe for the study of cellular regulation. Trends Biochem. Sci 15:98-102

Davis, P.D., Hill, C.H., Lawton, G., Nixom, J.S., Sedgwick, A.D., Wadsworth, J., Westmacott, D., and Wilkinson, S.E. (1989) Potent selective inhibitors of protein kinase C. FEBS Lett. $259: 61-63$

Dieter, P., and Fitzke, E. (1991) RO 31-8220 and RO 31-7549 show improved selectivity for protein kinase $C$ over staurosporine in macrophages. Biochem. Biophys. Res. Commun. 181:396401

Friedman, H.M., Macalrak, E.J., MacGregor, R.R., Wolfe, J., and Kefalides, N.A. (1981) Virus infection of endotheliat cells. U.' Infect. Dis 143:266-273

Heller, R., Bussolino, F., Ghigo, D., Garbarino, G., Schröder, H., Persiciarmona, G., Till, U., and Bosia, A. (1991) Protein kinase $C$ and cyclic AMP modulate thrombin-induced plateletactivating factor synthesis in human endothelial cells. Biachim. Biophys. Acta 1093:55-64

Ho, D.D, Rota, T.R., A.ndrews, C.A., and Hirsch, M.S. (1984) Replication of human cytomegalowirus in endothelial cells. J. Intect. Dis. 150:956-957

Ho, M. (1991) Cytomegalowirus. Biology and infaction. Plenum Medical Book Company, New York; p. 440

Jaffe, E.A., Hoyer, L.W." and Nackerman, R.L. (1973) Synthesis of antihemophilic factor antigen by cultured endothelial cells. J. Clin. Invest. $522757-2764$

Legrand, A.B., Narayanan, T.K., Ryan, U.S., Aronstam, R.S., and Catravas, J.D. (1989) Modulation of adenylate cyclase activity in cultured bovine puimonary arterial endothelial cells. Biochem. Pharmacol 38:423-430

Melnick J.L.y and Schattner, A. (1992) Viruses and atherosclerosis. J. Med. Sci $28: 463$ 465

Michelson, S., Alcamil, J., Kim, S.J., Danielpour, D., Bachelerie, F., Picard, L., Bessia, C., Paya, C., and Virelizier, J.L. (1994) Human cytomegalovirus infection induces transcription and secretion of transforming growth factor B1. U. Virol. 68:5730-5737

Nokta, M., Eaton, D., Steinsland, O.S., and Albrecht, T. (1987) $\mathrm{Ca}^{24}$ responses in cylomegalowirusinfected fibroblasts of human origin. Wirology 157:259-267

Petersen, C.M., Christensen, E.I., Andersen, B.S. "and Moller, B.K. (1992) Internalization, iysosomal degradation and new sythesis of the surface membrane CD4 in phorbol esteractivated T-lymphocytes and U-937 cells. Cell Res. 201:160-173

Sharkey, N.A., and Blumberg. P.M. (1985) Kinetic evidence that 1,2-diolein inhibits phorbol ester binding to protein kinase $C$ via a competitive mechanism. Biochem. Biophys, Res. Commun. 133: $105 \%-1056$ 


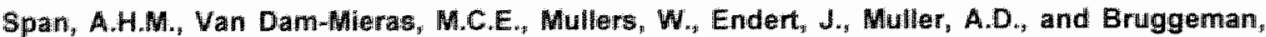
C.A. (1991) The effect of virus infection on the adherence of leukocytes or platelets to endothelial cells. Eur. J. Cin. Invest. 21:331-338

Span, A.H.M., Mullers, W., Miltenburg, A.M.M., and Bruggeman, C.A. (1991) Cytomegalovirus induced PMN adherence in relation to an ELAM-1 antigen present on infected endothelial cell monolayers. Immunology 72:355-359

Speir, E., Modali, R., Huang, E-S.s Leon, M.B., Shawl, F., Finkel, T., and Epstein, S.E. (1994) Potential role of human cytomegalovirus and p53 interaction in coronary restenosis. Science 265:391.394

Stagno, S., Pass, R.F., Dworsky, M.E., Henderson, R.E., Moore, E.G., Walton, P.D., and Alford, C.D. (1982) Congenital cytomegalovirus infection. The relative importance of primary and current maternal viral infections. N. Engl. J. Med. 306:345-349

Vanhoutte, P.M. (1990) Vascular effects of serotonim and ischemia. \& Cardiovasc. Pharmacol. $16: 515-519$

Valyi-Nagy, T., Bandi, Z, Boldogh, I., and Albrecht, T. (1988) Hydrolysis of inositol lipids: an early signal of human cytomegalovirus infection. Arch. Wirol. 101:199-207

Vercelloti, G.M. (1995) Potential role of viruses in thrombosis and atherosclerosis. Trends Cardiovasc Med. 5:128-133

Vossen, R.C.R.M., Derhaag, J.G., Slobbe-van Drumen, M.E.P., Duijuestijn, A.M., van Dam-Mieras, M.C.E., and Bruggeman, C.A. (1996) A dual role for endothelial cells in cytomegalovirus infection? A studly of cytomegalovirus infection in a series of rat endothelial cell lines. Virus Research, in press

Woodroffe, S.B., Garnett, H.M., and Danis, V.A. (1993) Interleukin-1 production and cell-activation response to cytomegalovirus infection of vascular endothellal cells. Arch. Virol. 133:295-308

Yoshimoto, T., Yoshimoto, E., and Muruelo, D. (1992) Enhanced gene expression of the murine ecotropic retroviral receptor and its human homologue in proliferating cells. J. Virol. 66:43774381 
NUCLEAR IMPORT AS A BARRIER TO INFECTIION OF HUMAN UMBILICAL VEIN ENDOTHELIAL CELLS BY HUMAN CYTOMEGALOVIRUS STRAIN AD169

M.E.P. Slobbe-van Drunen, A.T.M. Hendrickx, R.C.R.M. Vossen, E.J.M. Speel, M.C.E. van Dam-Mieras and C.A. Bruggeman 


\section{SUMMARY}

Human embryonal fibroblasts (HEF) are fully permissive for infection by human cytomegalovirus (HCMV) strain AD169, whereas human umbilical vein endothelial cells (HUVEC) seem to form an almost complete barrier to infection with this virus. To investigate this difference in permissiveness, HCMV infection of both cell types was studied using in situ hybridisation (ISH) as well as immunocytochemistry to detect viral DNA and viral proteins. At 2 hours post-infection (p.i.), viral DNA was detected dispersed throughout the cytoplasm in both HEF and HUVEC, indicating that HCMV enters all cells of both cell types. At 4 hours p.i., the viral DNA was found in the nucleus in HEF, and at the same time expression of immediate early (IE) antigen was found. In contrast, in HUVEC the expression of the IE proteins occurred in a limited number of cells at 8 hours p.i., while in most HUVEC an accumulation of viral DNA around the nuclei was abserved at this time point. In HUVEC, the nuclear localisation of viral DNA was detected 16 hours p.i. in a minority of cells, indicating that transport of HCMV DNA into the nucleus is considerably slower in HUVEC than in HEF. Furthermore, the number of HUVEC containing HCMV DNA decreased about six-fold between 8 and 48 hours p.i., indicating that HCMV DNA is either transported into the nucleus or eliminated. Apparently, the lower permissiveness of HUVEC for the HCMV strain AD169 relative to HEF is due to inefficient transport of HCMV DNA into the nuclei of infected HUVEC. 


\section{INTRODUCTION}

Infection of healthy individuals by cytomegalovirus (CMV) is usually asymptomatic but results in a latent infection. Under conditions of immunosuppression, such as in transplant patients and in patients with AIDS, symptomatic CMV infection can occur (Merigan and Resta, 1990). In these patients almost all organs are infected and CMV is found in a variety of cells, such as fibroblasts, epithelial cells, smooth muscle cells, macrophages, polymorphonuclear leukocytes and endothelial cells (Meyerson et al., 1984, Roberts et al., 1989, Sinzger et al., 1995).

The interaction between CMV and cells is intriguing. since the outcome of the infection process depends upon several factors. Firstly, the virus strain, since the infectivity for a cell adapted virus strain is higher than for the laboratory strains (Waldman et al., 1989). Secondly, the host cell type influences the infection process. For instance, human umbilical vein endothelial cells and retinal pigment epithelial cells are less permissive for CMV than fibroblasts and smooth muscle cells (Slobbe van Drunen et al., 1997, Detrick et al., 1996). Differences in the infectivity are also found between different endothelial cells. Microvascular endothelium is infected to a greater extent than large vessel endothelium (Persoons et al., 1998; Span et al., 1993; Lathey et al., 1990). Thirdly, cellular stimulation influences the infection level of host cells. For example, activation of endothelial cells by centrifugation or by pretreatment with phorbol myristoy $\|$ acetate (PMA) increases the infection efficiency (Vossen et al., 1996, Slobbe van Drunen et al., 1997).

Differences in CMV permissiveness between various cell types may reside at different stages. The entry of the virus into the host cell may be inhibited, the transport of the viral DNA to the nucleus may be hindered, the expression of viral genes suppressed or the cell-to-cell spread across the lateral membrane may be inhibited (Baskar et al., 1996, Maidji et al., 1996). To study this we used two different cell types, human umbilical vein endothelial cells (HUVEC) and human embryonic fibroblasts (HEF) as a model system to investigate the HCMV infection process by the laboratory strain AD169.

The results indicate that the lower permissiveness of HUVEC compared to HEF for AD169 infection is not caused by difference in virus entry into the cell but by a less efficient nuclear transport of the virus in HUVEC than in HEF. 


\section{Methods}

\section{Virus culture}

HCMV strain AD169 was propagated in human embryonal fibroblasts (HEF, Flow 2002) in Earle's Modified Eagle Medium ( $I C N$ Zoetermeer, The Netherlands), supplemented with $2 \%$ ( $v / v$ ) foetal calf serum (integro, Zaandam, The Netherlands). The cleared supernatants of the fibroblast monolayers, displaying $90-100 \%$ cytopathic effect, were stored at $-70^{\circ} \mathrm{C}$. Virus titres were determined by plaque titration assays in $\mathrm{HEF}$.

\section{Cell culture}

HUVEC were isolated from umbilical cords as described previously (Span et al., 1991).

The cells were propagated in wells coated with fibronectin, and grown in a medium (HUVEC medium) consisting of 40\% (v/V) M199 (Gibco, Breda, The Netherlands), $40 \%(\mathrm{v} / \mathrm{v})$ RPMI-1640 (Gibco), 20\% (v/v) foetal calf serum, $20 \mathrm{U} / \mathrm{m} /$ heparin sodium salt (ICN), $2 \mathrm{ml} / /$ bovine brain extract (Ho et al., 1984) $200 \mathrm{mM}$ L-glutamine (Serva, Heidelberg, Germany) and $50 \mu \mathrm{g} / \mathrm{ml}$ gentamicin (AUV, Cuyk, The Netherlands). All experiments were performed with cells of passages 2-6.

HEF were cultured in Earle's Modified Eagle Medium (EMEM, ICN Biomedicals, Zoetermeer, The Netherlands) containing 10\% newborn calf serum (PAN systems, Aidenbach, Germany), $200 \mathrm{mM}$ L-glutamine and non-essential amino acids (ICN Biomedicals, Zoetermeer, The Netherlands)

\section{Infection}

Cells were grown to confluency on chrome alum coated slides. One hour before infection, HUVEC were washed with phosphate buffered saline (PBS, $0.14 \mathrm{M} \mathrm{NaCl}$, $3 \mathrm{mM} \mathrm{KCl}, 6.5 \mathrm{mM} \mathrm{Na}_{2} \mathrm{HPO}_{4}$ and $1.5 \mathrm{mM} \mathrm{KH}_{2} \mathrm{PO}_{4} \mathrm{pH} \mathrm{7.2)} \mathrm{and} \mathrm{incubated} \mathrm{in} \mathrm{infection}$ medium, which was composed of Iscove's modified Dulbecco medium (IMDM, Gibco) supplemented with $15 \%$ ( $/ / v)$ foetal calf serum, $200 \mathrm{mM} \mathrm{L-glutamine} \mathrm{and} 50$ $\mu \mathrm{g} / \mathrm{ml}$ gentamycin at $37^{\circ} \mathrm{C}$. Subsequently, the cells were washed with PBS, incubated with HCMV in infection medium. HEF infection medium contained EMEM with $2 \%$ newborn calf serum, $200 \mathrm{mM} \mathrm{L}$-glutamine, and non-essential amino acids. The cells were centrifuged with HCMV for $45 \mathrm{~min}$. at $700 \mathrm{~g}$ at $20^{\circ} \mathrm{C}$, followed by 15 min incubation at $37^{\circ} \mathrm{C}$. After one hour of infection, the infection medium was replaced by HUVEC medium for endathelial cells and HEF infection medium for 
HEF. At the indicated times after infection $(2,4,8,24$ and 48 hours) the cells were fixed as described below.

\section{Detection of viral antigens by immunofluorescence staining.}

The expression of HCMV immediate early (IE) and late (L) antigens was followed at various time intervals after infection in both cell types by immunofluorescence. The HCMV IE antigen was detected using the E13 monoclonal antibody (Biosoft, Varilhes, France) and the $L$ antigen was detected using the SL-20 monoclonal antibody (Biosoft) (Gleaves et al., 1985). HEF and HUVEC were infected with HCMV using centrifugation ( $45 \mathrm{~min} .700 \mathrm{~g}$ ), and after different time periods, the cells were fixed with methanol for IE antigen detection and with acetone for $L$ antigen detection. The cells were then preincubated with $0.1 \%(w / v)$ bovine serum albumin (BSA) in PBS and incubated with the E13 or SL-20 monoclonal antibody (in a dilution of

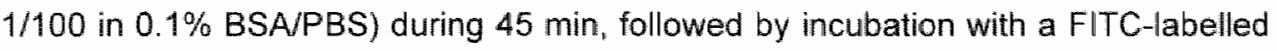
rabbit anti-mouse antibody (DAKO, diluted $1 / 80$ in $0.1 \%$ BSA/PBS) during $45 \mathrm{~min}$. Nuclei were subsequently stained with $0.5 \mathrm{ng} / \mathrm{ml}$ 4',6-diamino-2-phenyl indole (DAPI) in PBS containing 2.3\% (w/v) 1,4-diazobicyclo-(2,2,2)-octane (DAPCO). The infection degree was determined by counting the number of FITC-positive cells as well as the total number of nuclei in three different wells (four microscopic fields per welli).

\section{Detection of genomic HCMV by in situ hybridisation.}

The HCMV genome was detected using in situ hybridisation (ISH). For this purpose four different cosmid probes, PCM 1049,1052,1072 and 1106, were used to detect HCMV DNA (Fleckenstein et all, 1982). Biotinylation of these probes was performed using biotin-11-dUTP in a nick translation reaction as described by the manufacturer's instructions (GIBCO BRL, Gaithersburg, USA).

Methanol acetone fixed cells were pre-treated with pepsin from porcine stomach mucosa (2500-3500 U/mg protein; Sigma, St. Louis, USA) at a concentration of 100 $\mu \mathrm{g} / \mathrm{ml}$ in $0.01 \mathrm{M} \mathrm{HCl}$ for $10 \mathrm{~min}$. at $37^{\circ} \mathrm{C}$. After washing with $0.01 \mathrm{M} \mathrm{HCl}$, the slides were dehydrated in ethanol and subsequently post-fixed with 1\% paraformaldehyde in PBS containing $50 \mathrm{mM} \mathrm{MgCl} 2$ for $10 \mathrm{~min}$. (Speel et al., 1994). The cells were washed with $\mathrm{PBS}$ and $\mathrm{H}_{2} \mathrm{O}$ and dehydrated in ethanol.

The DNA probes were resolved in 50\% formamide, $2 * \mathrm{SSC}, \mathrm{pH} 5.0,5 \mathrm{ng} / \mu \mathrm{l}$ herring sperm DNA as carrier DNA and $5 \mathrm{ng} / \mu \mathrm{l}$ Yeast tRNA as carrier RNA at a probe concentration of $40-100 \mathrm{pg} / \mu \mathrm{l}$ in hybridisation mixture. After denaturation at $70^{\circ} \mathrm{C}$ for 3 min., hybridisation was performed overnight at $37^{\circ} \mathrm{C}$. Slides were washed in $50 \%$ 
formamide, $2^{*} \mathrm{SSC}, 0.05 \%$ Tween $20\left(\mathrm{pH} \mathrm{7.2)}\right.$ for $10 \mathrm{~min}$. at $42^{\circ} \mathrm{C}$, followed by $2^{*} \mathrm{SSC}(\mathrm{pH} 7.2)$ at $42^{\circ} \mathrm{C}$ for $10 \mathrm{~min}$. and with $4^{*} \mathrm{SSC}, 0.05 \%$ Tween $20(\mathrm{pH} 7.2)$ for 5 min. at RT.

The biotinylated probes were detected using mouse anti-biotin antibody (diluted $1 / 100$ in $5 \%$ non-fat dry milk PBS solution; DAKO, Glostrup, Denmark) and by rabbit anti-mouse antibody conjugated with peroxidase (RAMPO, diluted $1 / 200$ in $5 \%$ nonfat dry milk in PBS, DAKO). Detection of peroxidase activity was performed as described by Graham and Karnovsky (Graham and Karnovsky, 1966) using $\mathrm{H}_{2} \mathrm{O}_{2}$ and DAB (SIGMA).

\section{RESULTS}

The objective of the study was to compare the interaction of the HCMV strain AD169 with HUVEC, showing a limited permissiveness for AD169, with HEF, which are fully permissive for AD169. The sequence of events that occurs after the incubation of HUVEC and HEF with HCMV AD169 was studied by in situ hybridisation (ISH) and immunocytochemistry.
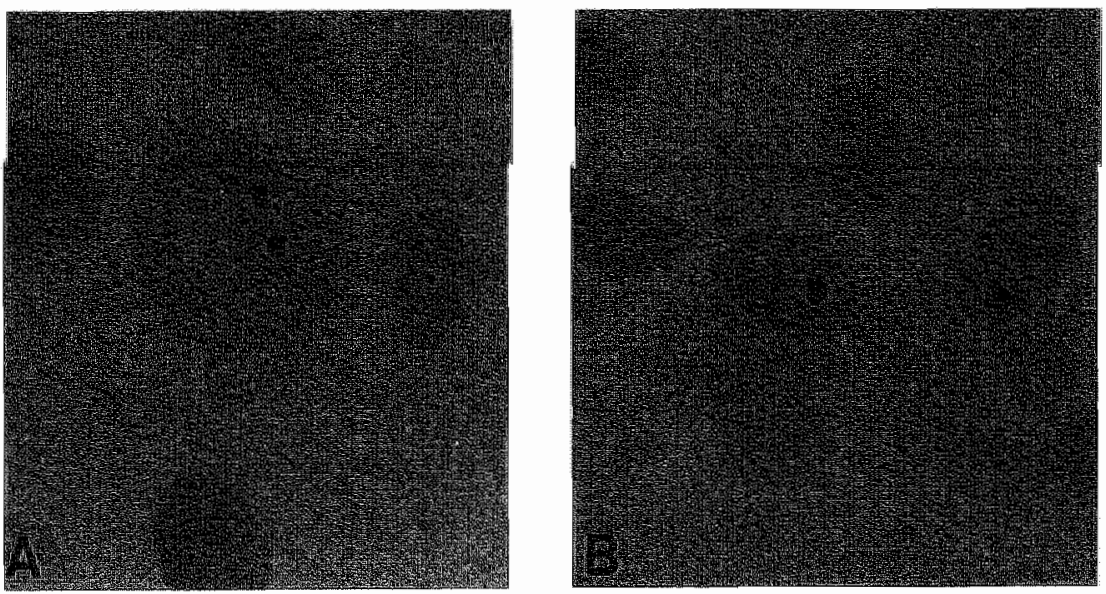

Fig. 1. Influence of RNase treatment.

HUVEC were infected for 48 hours with HCMV and fixed with methanol acetone The cells were treated with $100 \mathrm{ug} / \mathrm{ml}$ RNase A for $1 \mathrm{hr}$ at $37 \mathrm{C} \mathrm{in} 2^{*} \mathrm{SSC} \mathrm{pH7.2}$ before the hybridisation. (A) control and (B) RNase treated cells. Magnification: 1000* 


\section{HCMV DNA/RNA detection}

HUVEC and HEF were grown on slides and were infected with HCMV AD169 and fixed after different periods of time. For the detection of HCMV DNA/RNA four different biotin- labelled HCMV probes were used. To discriminate between viral RNA and DNA, the fixed cells were treated with RNase. The RNase treatment did not influence the HCMV ISH signal of the infected cells at 2, 4 and 8 hours, indicating that at these stages the ISH signal represents viral DNA. The cytoplasmic signals at later time points of infection represent mostly viral RNA, since incubation with RNase significantly decreased the intensity of this signal (Fig. 1).

Two hours after infection, a dispersed cytoplasmic ISH signal was found in all infected HUVEC and infected HEF (Fig. 2A, 1A), indicating that the virus enters all cells of both cell types. At 4-8 hours p.i. in HUVEC, the ISH signal becomes increasingly localised around the nucleus (Fig. 2B and $\mathrm{C}$ ), whereas such an accumulation is not found in HEF. A further difference between the infection process in HEF and HUVEC is that in HUVEC a nuclear ISH signal can only be detected at 16 hours p.i. (results not shown) while in HEF HCMV DNA can be detected in the nucleus already within 4 hours p.i. (Fig 3B). Another interesting phenomenon between the infection process in HUVEC and HEF is that a decrease in ISH signal was noted in HUVEC. In these cells, the number of cells displaying HCMV ISH signals decreased from about $60 \%$ at $8 \mathrm{~h}$ p.i.(Fig $2 \mathrm{C}$ ) to less than $10 \%$ at 48 hours p.i. (Fig 4A). In contrast, virtually all HEF remained positive as determined by ISH. Finally, in the limited number of virus-infected HUVEC, 2-3 nuclear ISH domains were found, while in HEF the number of domains was at least 3 (Fig 4), suggesting that in HEF more virus replication sites are present than in HUVEC.

\section{HCMV antigen detection}

As described above, viral DNA resides longer in the cytoplasm of HUVEC than in the cytoplasm of HEF. To investigate if this would lead to a delayed expression of viral proteins, we studied the infection process by immunocytochemistry using monoclonal antibodies directed against immediate early (IE) and late (L) HCMV antigens. AD169 infected cells showed a nuclear staining with the IE antigen and a cytoplasmatic staining with the L- antigen. The expression of these antigens after infection with AD169 took more time in HUVEC than in HEF. As shown in Table 1, fibroblasts already expressed the HCMV IE antigen 4 hours postinfection (p.i.) while in endothelial cells the IE expression started only at 8 hours p.i.. The L antigen was detected in HEF 24 hours p.i. and in HUVEC 48 hours p.i. These results 

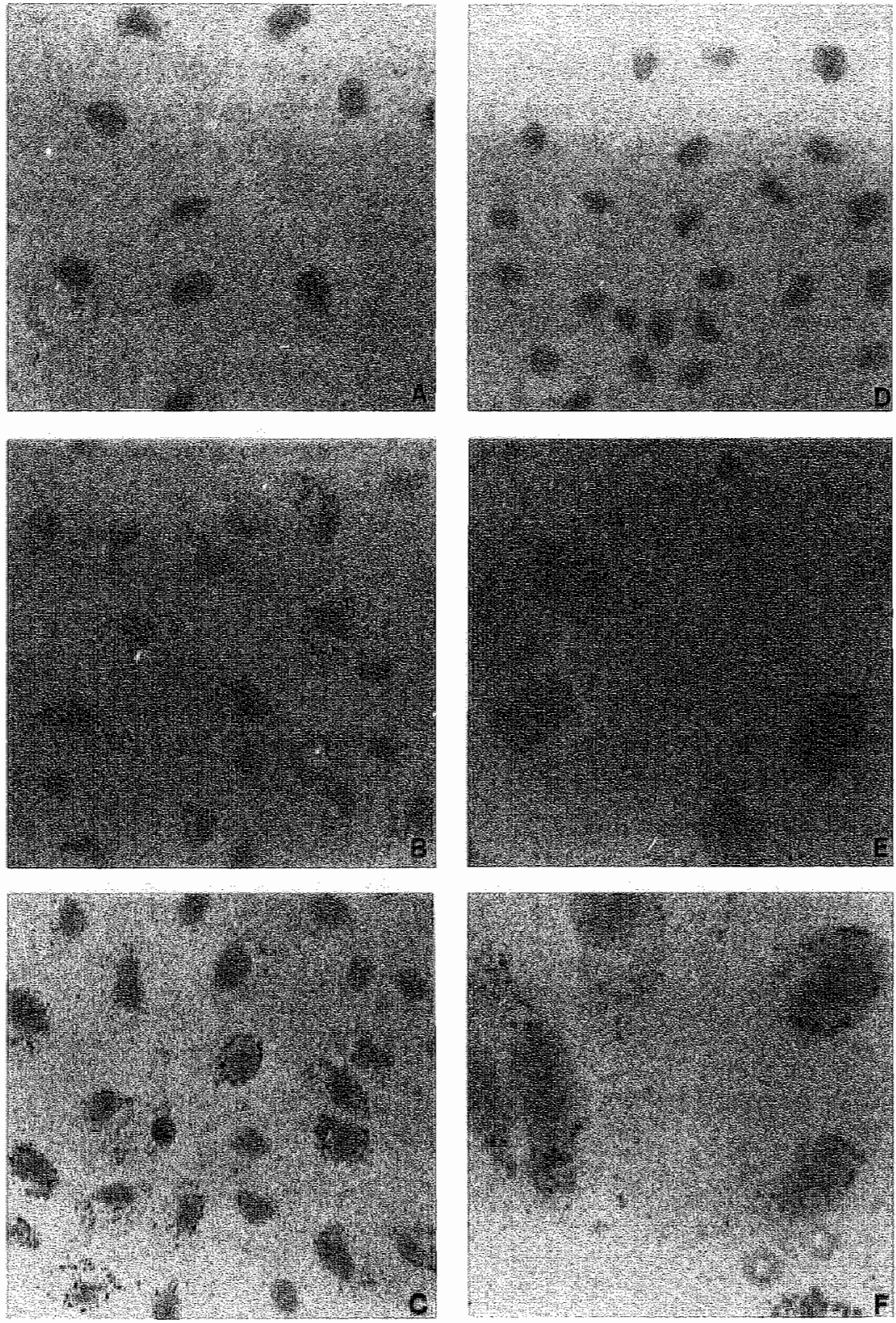

Fig. 2. Detection of HCMV in HUVEC by ISH technique.

Biotin-labelled genomic HCMV probes were used for the hybridisation with non infected (D) and infected (A,B,C,E and $F$ ) cells. HCMV was detected by PO-DAB precipitate. HUVEC were infected with MOI 3.5 for different time periods, $(A) 2$ hours, $(B$ and $E) 4(C$ and $F) 8$ hours Magnifications: (A-D), 400*; (E and F), 1000* 

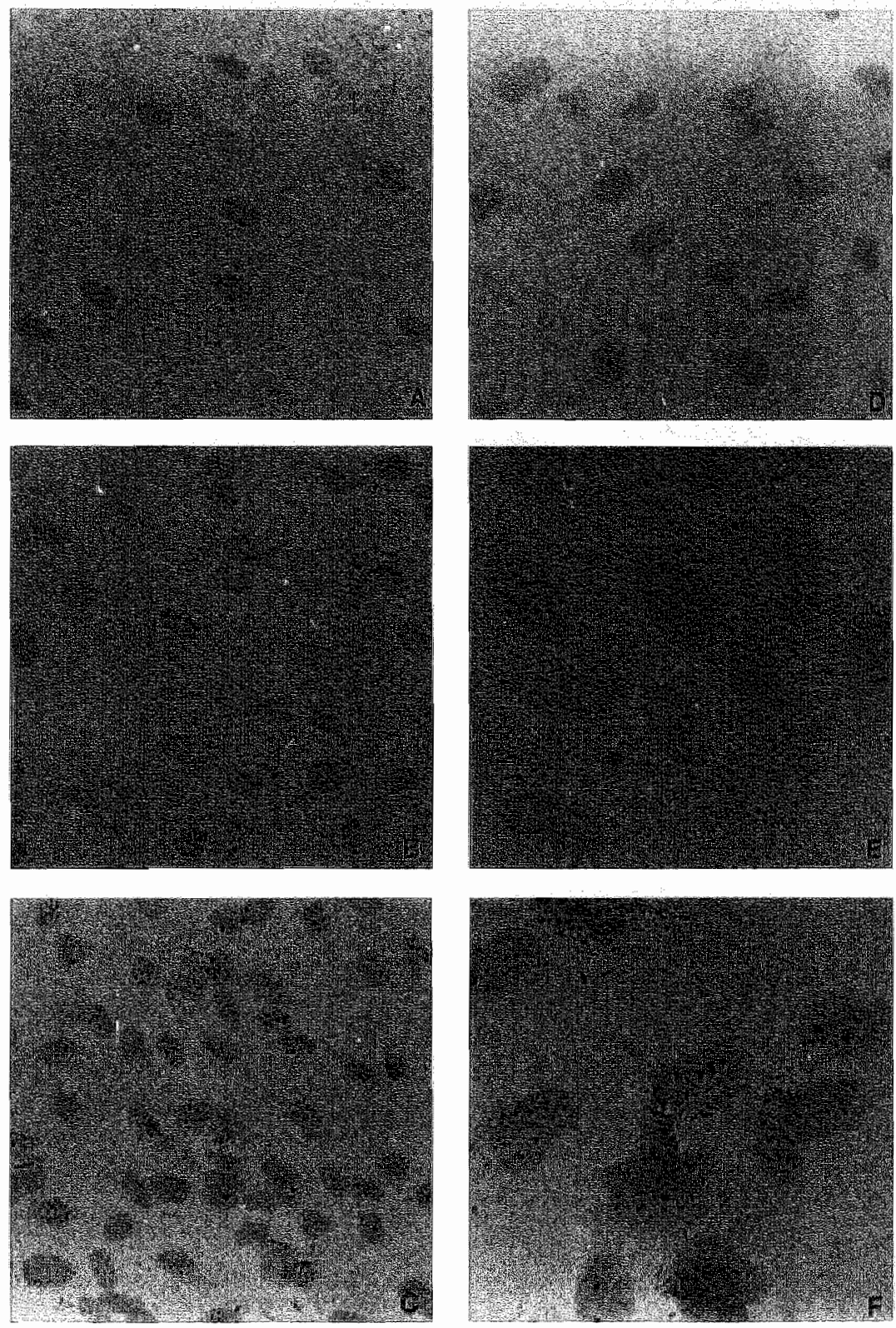

\section{Fig. 3 Detection of HCMV in HEFs by ISH technique.}

HEFs, were infected with MOI 2 for different time periods; (A) 2 hours, (B and $E$ ) 4 thours and (C and F) 8 hours (D) non infected cells. Biotin-labelled geriomic HCMV probes were used for the detection of HCMV. Magnifications: (A-D), 400\%: (E and F), 1000" 

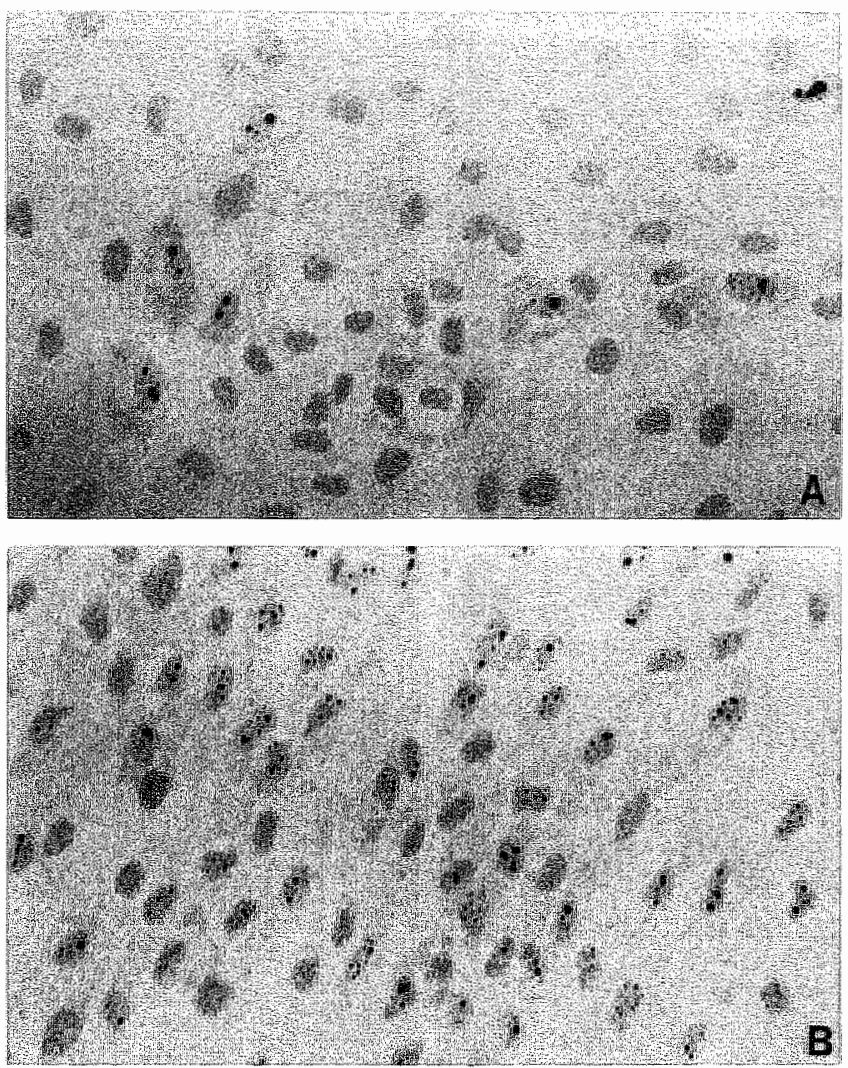

Fig. 4 HCMV infection in HUVEC and HEF.

HCMV was detected with the ISH technique 2 days after infection in (A) HUVEC (MOI 3.5) and (B) HEF (MOI 0.4). Magnification: $400^{*}$

demonstrate that the expression of the $\mathrm{IE}$ and $\mathrm{L}$ antigens is delayed in HUVEC

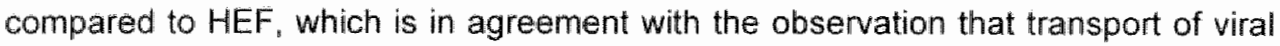
DNA is slower in HUVEC than in HEF.

Two days after infection almost all HEF expressed the IE and $L$ antigen while only 1$5 \%$ of the HUVEC expressed these antigens. This number of HCMV positive cells as detected with immunohistochemistry is in accordance with the number of HCMV positive HUVEC at 48 hours p.i. using the $\triangle S H$ technique.

With both techniques, ISH and immunohistochemistry, we found that the infection process is delayed in HUVEC compared to HEF. This delay in HUVEC seems to be due to the longer residence of viral DNA in the cytoplasm. Furthermore, the ISH results indicates that the limited permissiveness of HUVEC is not due to a decreased viral entry. 
Table 1 Detection of HCMV IE anfigen and L antigen expression in HUVEC and HEF

(A)

\begin{tabular}{|c|c|c|}
\hline time after infection & HUVEC & HEF \\
\hline 2 hours & $0 \%$ & $0 \%$ \\
\hline 4 hours & $0 \%$ & $45 \%$ \\
\hline 6 hours & $0 \%$ & $66 \%$ \\
\hline 8 hours & $1 \%$ & $72 \%$ \\
\hline 16 hours & $3 \%$ & $87 \%$ \\
\hline 24 hours & $5 \%$ & $84 \%$ \\
\hline 48 hours & $3 \%$ & $94 \%$ \\
\hline
\end{tabular}

(B)

\begin{tabular}{|c|c|c|}
\hline time after infection & HUVEC & HEF \\
\hline 24 hours & $0 \%$ & $50 \%$ \\
\hline 48 hours & $1 \%$ & $90 \%$ \\
\hline 72 hours & $1 \%$ & $95 \%$ \\
\hline
\end{tabular}

HUVEC and HEF were infected with HCMV multiplicity of infection (MOH) of 3.5 and 0.4 respectively) for different time periods. HCMV infected cells were detected by a $I E$ antigen $(A)$ and $L$ antigen (B). The infection percentage was determined by counting the number of HCMV positive cells as well as the total number of nuclei.

\section{DISCUSSION}

Our results show that there is a clear difference between the sequence of events that takes place after incubation of HCMV AD 169 with HUVEC and that occurring after incubation of the virus with HEF. The ISH results show that the virus enters both cell types in a similar degree, but after entry the fate of the wirus is different in both cell types. In HEF, the viral DNA is transported to the nucleus where transcription and replication takes place. In HUVEC, transport of the viral DNA into the nucleus occurs only in a limited number of cells (less than 10\%) and the viral DNA seems to be eliminated from those cells where transport of viral DNA into the nucleus fails. These results are in good agreement with the results obtained using monoclonal antibadies directed against viral IE and $L$ antigens. Antigen expression was detected in only $1-10 \%$ of the HUVEC while in HEF almost all cells expressed these antigens. 
Our results are supported by the observation of Nowlin et al (Nowlin et al., 1991) describing that binding of HCMV to HUVEC and HEF was comparable. In this study it was concluded that the difference in permissiveness was not due to differences of virus binding to these cells.

Our data show that after entry, wiral DNA reaches the nucleus of HEF already at 4 hours p.i., while in HUVEC viral DNA was first detected in the nucleus at 16 hours p.i. This indicates that the residence time of viral DNA in the cytoplasm is longer in HUVEC than in HEF. The delay in the expression of viral antigens in HUVEC can probably be ascribed to this delay in transport of viral DNA to the nucleus. Such cellspecific differences in the time course of HCMV gene expression have also been described for monocyte-derived macrophages and retinal pigment epithelial cells, which also showed a delay in the expression of viral antigens or a delay in the virus production compared to fibroblasts (Fish et al., 1995, Detrick et al., 1996). In HUVEC the viral DNA seems to be eliminated in the cytoplasm because during the infection process the number of cells containing viral DNA decreases between 2 and 48 hours p.i. From these data it can be concluded that only in 5-10\% of HUVEC the viral DNA enters the nucleus, resulting in viral transcription and replication in only a subset of the initially AD169 positive cells. Since an accumulation of viral DNA is observed around the nucleus of infected HUVEC prior to this decrease, it seems as if transport of viral DNA into the nucleus, crucial for the initiation of viral transcription and replication, is hampered in HUVEC. This could very well explain the limited permissiveness of HUVEC for AD169 HCMV. For endothelial cell tropic HCMV strains it is likely that the transport of the virus to the nucleus is not hampered in HUVEC, since the permissiveness of HUVEC for this virus strain is high.

Similar observations have been described previously for other viruses such as adenovirus and human immunodeficiency virus (HIV). For those viruses the effect was explained by changes in viral protease activity, suggesting that the disassembly of the virus seems to be necessary for transport into the nucleus (Greber et al., 1996, Nagy et al., 1994). It has also been described that such viral protease activity is regulated by the oxidative status of the cells (Greber et al., 1996, Baum et al., 1996. Davis et al., 1996), which would be in agreement with our previous observation that the intracellular redox status of endothelial cells affects their CMV permissiveness (Vossen et al., 1997).

To our knowledge this is the first evidence that restricted permissiveness of CMV in a specific cell type is not caused by limited viral entry. Instead, the viral DNA is not efficiently transported to the nucleus of HUVEC, which eventually may lead to a limited permissiveness. This implies that reduction of transport of viral DNA from the 
cytoplasm into the nucleus by means of anti-viral compounds could potentially be of significant value in reducing HCMV viral loads.

\section{ACKNOWLEDGEMENT}

This work was supported by the Biomed 2 European Concerted Action project number BMH-4-CT96-0471(DG12-SSMA).

\section{REFERENCES}

Baskar, J.F., Smith, P.P., Nilaver, G., Jupp, R.A., Hoffmann, S., Peffer, N.J., Ghazal, P. and Neison N.A. (1996) The enhancer domein of the human cytomegalovirus inajor immediateearly promotor determines cell type-specific expression in transgenic mice. J. Virol. 70 : $3207-3214$

Baum, E.Z., Siegel, M.M., Bebernitz, G.A., Hulmes, J.D., Sridharan, L., Sun, L., Tabel, K., Johnston, S.H., Widley, M.J., Nygaard, J., Jones, T.R. and Gluzman, Y. ("1996) Inhibition of human cytomegalovirus ULBO protease by specific intramolecular disulfide bond formation. Biochemistry $35: 5838-5846$

Davis, D.A., Dorsey, K., Wingfield, P.T., Stahl, S.J., Kaufman, J., Fales, H.M. and Levine, R.L. (1996) Regulation of HIV.4 protease activity through cysteine modification. Biochemistry 35 2482-2488

Detrick, B., Rhame, J., Wang, Y., Nagineni, C.N. and Hooks, J.J. (1996) Cytomegalovirus replication in human retinal pigment epithellial cells. Altered expression of viral early proteins. Invest. Ophthaimol. Vis. Sci. 37(5): 814-25

Fish, K.N., Depto, A.S., Moses, A.V., Britt, W. and Nelson, J.A. (1995) Growth kinetics of human cytomegalovirus are altered in monocyte-derived macrophages. $J$. Wrol $69(6): 3737-43$

Fleckenstein, B., Müller, I. and Collins, J. (1982) Cloning the complete human cytomegalovirus genome in cosmids. Gene 18:39-46

Gleaves, C.A., Smith, T.F., Shuster, E.A. and Pearson, G.R. (1985) Comparison of standard tube and shell vial culture techriques for the detection of cytomegalowirus in clinical specimens. $J$. Clin. Microbjology 21 : 217-221

Graham, R.C. and Karnovsky, M.J. (1966) The early stages of absorption of injected horseradish peroxidase in the proximal tissue of the mouse kidney with structural cytochemistry by a now technique. U. Histochem. Cytochem 14: 291-302

Greber, U.F., Webster, $P_{\text {., }}$ Weber ${ }_{1}$ J. and Helenius, A. (1996) The role of the adenowirus protease on virus entry into celis. EMBO $/ 15(8)$ : $1766-77$

Ho, D.D., Rota, T.R., Andrews, C.A. and Hirsch, M.S. (1984) Replication of human cytomegalovirus in endothelial cells. J. Infect. Dis. 150: 956-957

Lathey "J.L., Wiley, C.A., Verity, M.A. and Nelson, J.A. (1990) Cultured thuman brain capillary endothelial cells are permissive for infection by human cytomegalovirus. Virology 176(1): 266-73

Maidji, E., Tugizov, $S_{.,}$Jones, T., Zheng, $Z$. and Pereira, L. (1996) Accessory human cytomegalowirus glycoprotein US9 in the unique sthort component of the viral genome promotes cell-to-cell transmission of virus in polarized epithelial cells. $J$. Virol. 70: 8402,8410

Merigan, T.C. and Resta, S. (1990) Cytomegalovirus where have we been and where are we going? Rev. Infect. Dis. 12(7): S693-700

Meyerson, D., Hackman, R.C., Nelson, J.A. and McDoughall, J.K. (1984) Widespread presence of histologically occult cytomegalovirus. Hum. Pathol 15: 430-438

Nagy, K., Young, M., Baboonian, C., Merson, J., Whittle, P. and Oroszlan, S. (1994) Antiviral activity of human immunodeficiency wirus type 1 protease inhibitors in a single cycle of infection: evidence for a role of protease in the early phase. $d$. Virol. 68(2): 757-765

Nowlin, D.M., Cooper, N.R. and Compton, T. (1991) Expression of a human cytomegalovirus receplor correlates with infectibility of the cells. J. Virol $65(6), 3114-3121$ 
Peraoons, M.C.J., Stals, F.S., van Dam-Mieras, M.C.E. and Bruggeman, C.A. (1998) Multiple organ involvement during experimental cytomegalovirus infection is associated with disseminated vascular pathology. J. Pathol. 184:103-109

Roberts, W.H., Sneddon, J.M., Waldman, J. and Stephens, R.E. (1989) Cytomegalovirus infection of gastrointestinal endothelium demonstrated by simultaneous nucleic acid hybridisation and immunohistochemistry. Arch. Pathol. Lab. Med. 113: 461-464

Sinzger, C.. Grefte, A., Plachter, B., Gouw, A.S.H., Hauw The, T. and Jalhm, G. (1995) Fibroblasts, epithelial cells; endothelial cells and smooth muscle cells are major targets of human cylomegalovirus infection in lung and gastrointestinal tissues. J. Gen. Virol. 76: 741-750

Slobbewan Drunen, M.E.P., Vossen, R.C.R.M., Couwenberg, F.M.D., Hulsbosch, M.M., Heemsikerk, J.W.M., Wan Dam-Mieras, M.C.E. and Bruggeman, C.A. (1997) Activation of protein kinase $C$ enhances the infection of endothelial cells by human cytomegalovirus Virus Res. 48: 207-213

Span, A.H., Frederik, P.M., Grauls, G., van Boven, G.P. and Bruggeman, C.A. (1993) CMV induced vascular injury: an electron-microscopic study in rat. In Vivo 7: 567-573

Span, A.H., Mullers, W., Miltenburg, A.M. and Bruggeman, C.A. (1991) Cytomegalovirus induced PMN adherence in relation to an ELAM-1 antigen present on infected endothelial cell monolayers. Immunology 72(3), 355-60

Speel, E.J.M., Jansen, M.P.H.M., Ramaekers, F.C.S. and Hopman, A.H.N. (1994) A novel triplecalor detection procedure for brightfield microscopy "combinding in situ hybridisation with immunocytochemestry. J. Histochem. Cytochem. 42: 1299-1307

Vossen, R.C.R.M., Derhaag, J.G., Slobbe-van Drunen, M.E.P., Duijvenstijn, A.M., van DamMieras, M.C.E. and Bruggeman, C.A. (1996) A dual role for endothelial cells in cytomegalovirus infection? A study of cytomegalovirus infection in a series of rat endothelial cell limes. Virus Res. 46: 65 74

Vossen, R.C.R.M., Persoons, M.C.J., Slobbe-van Drunen, M.E.P., Bruggeman, C.A. and van Dam-Mieras, M.C.E. (1997) Intracellular thiol redox status affects cytomegalovirus infection of vascular cells. Virus Res. 48: 173-183

Waldman, W.J., Sneddon, J.M., Stephens, R.E. and Roberts, W.H. (1989) Enhanced endothelial cytopathogenicity induced by a cytomegalovirus strain propagated in endothelial cells. $d$. Med. Virol. 28(4): 223-30 


\section{ENTRY OF CYTOMEGALOVIRUS IN HUMAN UMBILICAL VEIN ENDOTHELIAL CELLS}

Marlea E.P. Slobbe-van Drunen, Bahram Bodaghi, Andrzei Topilko, Renée C.R.M.

Vossen, Emmanuelle Perret, D. Zipeto, J.L. Virelizier, P. LeHoang, Susan Michelson " Maria C.E. van Dam-Mieras and Cathrien A. Bruggeman 


\section{SUMMARY}

For exploring factors involved in viral cell tropism of cytomegalovirus infection, virallhost cell interactions were investigated in more detail. Morphological and biochemical criteria showed that human cytomegalovirus (HCMV) penetrates human umbilical vein endothelial celis (HUVEC) by endocytotic uptake into smooth walled vesicles and not by direct viral fusion with the plasma membrane, as has been reported for HCMV in human fibroblasts (HEF).

HCMV infection was not affected by agents that interfere with endosome acidification, which indicates that $\| \mathrm{ow} \mathrm{pH}$ induced viral fusion is not involved in HCMV infection in HUVEC and HEF. Biochemical investigation showed a different cytochalasin B sensitivity of the pathways that mediate HCMV internalisation in endothelial cells and fibroblasts. Incubation with cytochalasin B decreased the HCMV infection in endothelial cells but not in fibroblasts. Furthermore, detection of viral internalisation by in situ hybridisation showed an accumulation of the virus around the endothelial nuclei as opposed to a rapid transport of HCMV into fibroblast nuclei.

We have shown that the HCMV virions enter endothelial cells by endocytotic uptake into vesicles, and that the infection is $\mathrm{pH}$-independent. 


\section{INTRODUCTION}

Cytomegalovirus (CMV), a species-specific member of the herpesvirus family, commonly infects immunocompetent individuals subclinically. However, in the immunosuppressed host CMV can become a serious pathogen associated with significant morbidity and mortality in a variety of clinical syndromes.

Observations in both humans and animals reveal that during acute infection under immunosuppressed conditions. CMV infects almost all organs (Myerson et all, 1984; Stals et al., 1990). There is increasing evidence for vascular involvement in such disseminated CMV infections. The mechanisms of the induction of the vascular pathology is unknown. Different cell types in the vascular wall seem to behave quite differently with respect to CMV infection (Vossen et al., 1997; Vossen et al., 1996). Human umbilical vein endothelial cells (HUVEC) show a low infectivity for the HCMV strain AD169, whereas smooth muscle cells and fibroblasts are productively infected by HCMV (Slobbe-van Drunen et al., 1997; Tumilowicz, 1990; Vossen et al., 1997). However, the factors that mediate this viral cell tropism are poorly understood. Differences in infection could be due to the level of viral entry, transport of the virus in the cytoplasm and the level of transcription and/or replication in the nucleus. It has already been shown that the low permissiveness of HUVEC for AD169 is not due to a limited viral entry (Slobbe-van Drunen et al., 1998). This does not mean that the mechanism of entry of the virus is the same in all cells. The viral entry process may influence the further processing of the virion within the cells. Therefore, a more detailed study of viral-host cell interactions is necessary.

The entry of enveloped viruses into animal cells involves virion binding to cell surface receptor(s) followed by either fusion of the viral envelope with the plasma membrane or by a process during which viruses are taken up in the cell within vesicles (by phagocytosis or endocytosis) (Lanzrein et al., 1994). Attachment of the enveloped virus to the host cell membrane is dependent on viral glycoproteins and cellular receptors (Hernandez et al., 1996). Viral internalisation most commonly occurs through clathrin-coated vesicles by receptor mediated endocytosis, although endocytosis in smooth walled vesicles and uptake in large smooth walled vesicular structures has also been documented (Bukrinskaya, 1982; Hernandez ef al., 1996). For enveloped viruses, this process is commonly followed by a $\mathrm{pH}$-dependent fusion between the viral envelope and the endosomal membrane. Alternatively, direct fusion between the viral envelope and the host cell plasmamembrane can occur. The latter is a $\mathrm{pH}$-independent fusion process. 
In general, herpesviruses enter host cells by fusion with the plasmamembrane. For example, herpes simplex virus enters epidermoid carcinoma and African monkey kidney cells by a pH-independent fusion with the plasmamembrane (Wittels and Spear. 1991). This mechanism is also used by human cytomegalovirus to enter fibroblasts (Compton et al., 1992). However, Epstein Barr virus (EBV), another herpesvirus, appears to enter lymphoblastoid (Raji) cells and epithelial cells by fusion with the plasma membrane, but entrance in B lymphocytes occurs via an endocytotic pathway (Miller and Hutt-Fletcher, 1992; Nemerow and Cooper, 1984). In both cases, EBV entry is pH-independent.

After internalisation the virus needs to be transported to the nucleus, where uncōating occurs and viral DNA enters the nucleus to initiate the viral transcription and replication processes (Bukrinskaya, 1982; White, 1990). Although much has been learned about the entry of enveloped viruses, less is known about the mechanism by which viruses reaches the site(s) of intracellular replication. The transportation of the attached virus to the nucleus will depend to a large extent on cellular mechanisms, and therefore will probably show resemblance to the internalisation of other extracellular material, for instance nutrients, hormones, or macromolecules. Since this varies between different cell types, it is likely that cell tropism for a particular virus will be dependent on both viral and cellular factors.

Until now relatively little is known about the intracellular processes involved for other less permissive cell types. It is not known whether differences in viral internalisation pathways are involved in the differences in cell tropism. Recently, we described that in endothelial cells the transport of HCMV to the nucleus is hampered, which might explain the low HCMV permissiveness for these cells (Slobbe-van Drunen et al., 1998).

In this paper, we investigate HCMV infection of endothelial cells in more detail using various techniques, such as electron microscopy, in situ hybridisation, immunofluorescence staining for viral antigens, and biochemical analysis of the early infection process. We show that the HCMV virions enter endothelial cells by endocytotic uptake into vacuoles and that the fusion process is $\mathrm{pH}$-independent while in fibroblasts the virus enters the cells through $\mathrm{pH}$ independent fusion with the plasmamembrane. 


\section{MATERIALS AND METHODS.}

\section{Virus culture}

HCMV strain AD169 was propagated in human embryonal fibroblasts (HEF) in Earle's Modified Eagle Medium (ICN, Zoetermeer, The Netherlands), supplemented with $2 \%(\mathrm{v} / \mathrm{v})$ foetal calf serum (Integro, Zaandam, The Netherlands). The cleared supernatants of the human embryonal fibroblasts (HEF) monolayers displaying 90$100 \%$ cytopathic effect, were stored at $-70^{\circ} \mathrm{C}$. Virus titre was analysed by a plaque titration assay in HEF.

\section{Endothelial cell culture}

HUVEC were isolated from umbilical cords as described previously (Slobbe-van Drunen et al., 1997). The cells were propagated in wells coated with fibronectin, and grown in a medium consisting of $40 \%$ ( $/ / \mathrm{W}) \mathrm{M} 199$ (Gibco, Breda, The Netherlands), 40\% (v/v) RPMI-1640 (Gibco), 20\% (v/v) Newborn calf serum (PAN system, Germany) $20 \mathrm{U} / \mathrm{ml}$ heparin sodium salt (ICN), $2 \mathrm{ml} / /$ bovine brain extract $200 \mathrm{mM} \mathrm{L}$ glutamine (Serva, Heidelberg, Germany) and $50 \mu \mathrm{g} / \mathrm{ml}$ gentamycin (AUV, Cuyk, The Netherlands). All experiments were performed with cells at passages 2 to 6 .

\section{Infection}

Cells were cultured till $95 \%$ confluency in 96 well culture plates (Costar, Badhoevedorp. The Netherlands) for biochemical experiments, in 12 well culture plates for EM experiments and on glass slides for ISH experiments. The cells were washed twice with phosphate buffered saline (PBS) and preincubated with IMDM supplemented with $15 \%(\mathrm{v} / \mathrm{v}$ ) Newborn calf serum (NCS), $200 \mathrm{mM}$ L-glutamine and $50 \mu \mathrm{g} / \mathrm{ml}$ gentamycin (15\% IMDM) for $1 \mathrm{hr}$ at $37^{\circ} \mathrm{C}$. Virus dilutions were made in IMDM supplemented with $2 \%$ (v/v) NCS, $200 \mathrm{mM} \mathrm{L-glutamine}$ and $50 \mu \mathrm{g} / \mathrm{ml}$ gentamycin ( $2 \%$ IMDM). The cells were inoculated at multiplicity of infection (MOI) of 3 for HUVEC and MOI of 0.5 for HEF with HCMV dilluted in 2\% IMDM by centrifugation for $45 \mathrm{~min}$ at $700 \mathrm{~g}$ at $20^{\circ} \mathrm{C}$, followed by a $25 \mathrm{~min}$ incubation at $37^{\circ} \mathrm{C}$. Subsequently, the inoculum was removed and the cells were incubated with growth medium for the indicated time.

In addition "for some experiments the cells were preincubated with infection medium containing biochemical agents (ammoniumchloride, chloroquine, dansylcadaverine and cytochalasin B) for $1 \mathrm{hr}$, infected with HCMV in the presence of these agents 
and refreshed with medium containing these agents for the indicated time (6 or 24 hr). The cells were fixed 24 hr after infection.

\section{Detection of viral antigen by immunofluorescence staining}

HUVEC were fixed with ice cold ethanol/acetone $(1: 1)$ solution for $10 \mathrm{~min}$. The cells were incubated for $1 \mathrm{hr}$ with the E13 monoclonal antibody, directed against HCMV immediate early protein, (Biosoft, Varilhes, France; in a dilution of $1 / 100$ in $0.1 \%$ BSA/PBS) and the monoclonal antibody F6b (igG2a) (Michelson et al 1984) which detects the HCMV tegument protein pp65. The slides were washed and incubated with $1 / 100$ dilution of fluorescein-conjugated anti-mouse IgG1 (DAKO) and 1/100 dilution of Texas-red-conjugated anti-mouse lgG2a (Southern Biatechno). After final washing, slides were fixed with $10 \%$ formol, mounted in $70 \%$ glycerol/PBS/2.3\% DAPCO followed by incubation with a FITC-labelled rabbit anti-mouse antibody (DAKO, Glostrup, Denmark; diluted $1 / 80$ in $0.1 \%$ BSA/PBS) for 45 min. The E13 antibody recognises the $76 \mathrm{kDa}$ nuclear HCMV immediate-early antigen. Nuclei were subsequently stained with $0.5 \mathrm{ng} / \mathrm{ml}$ 4'6-diamino-2-phenyl indole (DAPI) in PBS containing 2.3\% (w/v) 1,4-di-azobicyclo-(2,2,2)-actane (DAPCO).

\section{Detection of genomic HCMV by in situ hybridisation}

The HCMV genome was detected using in situ hybridisation (ISH). For this purpose four different cosmid probes, pCM 1049,1052,1072 and 1106, were used to detect HCMV DNA (Fleckenstein et al., 1982). Biotinylation of these probes was performed using biotin-11-dUTP in a nick translation reaction as described by the manufacturer's instructions (GIBCO BRL, Gaithersburg, USA).

Methanol acetone fixed cells were pre-treated with pepsin from porcine stomach mucosa (2500-3500 U/mg protein; Sigma, St. Louis, USA) at a concentration of 100 $\mu \mathrm{g} / \mathrm{ml}$ in $0.01 \mathrm{M} \mathrm{HCl}$ for $10 \mathrm{~min}$. at $37^{\circ} \mathrm{C}$. After washing with $0.01 \mathrm{M} \mathrm{HCl}^{\circ}$ the slides were dehydrated in ethanol and subsequently post-fixed with $1 \%$ paraformaldehyde in PBS containing $50 \mathrm{mM} \mathrm{MgCl}$ for $10 \mathrm{~min}$. (Speel et al., 1994). The cells were washed with PBS and $\mathrm{H}_{2} \mathrm{O}$ and dehydrated in ethanol.

The DNA probes were resolved in 50\% formamide, $2 * \mathrm{SSC}_{n} \mathrm{pH} 5.0,5 \mathrm{ng} / \mu \mathrm{l}$ herring sperm DNA as carrier DNA and $5 \mathrm{ng} / \mu \mathrm{l}$ Yeast IRNA as carrier RNA at a probe concentration of $40-100 \mathrm{pg} / \mu \mathrm{l}$ in hybridisation mixture. After denaturation at $70^{\circ} \mathrm{C}$ for 3 min., hybridisation was performed overnight at $37^{\circ} \mathrm{C}$. Slides were washed in $50 \%$ formamide, $2^{*} \mathrm{SSC}, 0.05 \%$ Tween $20(\mathrm{pH} 7.2)$ for $10 \mathrm{~min}$. at $42^{\circ} \mathrm{C}$, followed by $2^{*} \mathrm{SSC}(\mathrm{pH} 7.2)$ at $42^{\circ} \mathrm{C}$ for $10 \mathrm{~min}$. and with $4 * \mathrm{SSC}, 0.05 \%$ Tween $20(\mathrm{pH} 7.2)$ for 5 min. at room temperature. 
The biotinylated probes were detected using mouse anti-biotin antibody (diluted $1 / 100$ in $5 \%$ non-fat dry milk PBS solution; DAKO, Glostrup, Denmark) and rabbit anti-mouse antibody conjugated with peroxidase (RAMPO, diluted $1 / 200$ in $5 \%$ nonfat dry milk in PBS, DAKO). Detection of peroxidase activity was performed as described by Graham and Karnovsky(Graham and Karnovsky, 1966) using $\mathrm{H}_{2} \mathrm{O}_{2}$ and DAB (SIGMA).

\section{Electron Microscopy}

HUVEC were infected for $15 \mathrm{~min}$ or 2 and $8 \mathrm{hr}$. At each time point the cells were prefixed with $1.6 \%$ glutaraldehyde in $0.1 \mathrm{M}$ phosphate buffer $\mathrm{pH} 7.3$, rinsed in the same buffer, postfixed in 1\% osmium tetroxide, dehydrated in methanol and embedded in Epon in situ, in well. After resin polymerization, cells were cut tangentially and vertically to the basal surface of the plastic blocks. Ultra-thin sections were collected on uncoated grids and counterstained with uranyl acetate and lead citrate. Morphological analysis was performed in a "JEOL-JEM 100CX I" electron microscope.

\section{RESUILTS}

\section{Detection of HCMV DNA in the early stage of infection.}

To investigate the early stages of infection (virion entry and transport in the cytoplasm) , the viral protein pp65 and an immediate early protein and viral DNA were detected by respectively immunohistochemistry and in situ hybridisation (ISH). In fibroblasts pp65 can be detected in all nuclei $10 \mathrm{~min}$ after HCMV infection whereas in HUVEC only a very small amount of the nuclei become pp65 positive 6 $\mathrm{hr}$ after infection. All the other cells contain pp65 positive spots in the cytoplasm The endothelial cell in which pp65 can reach the nucleus are also positive for HCMV IE protein (Fig. 1).

With in situ hybridisation it was detected that two hours after infection viral DNA is in the cytoplasm of HUVEC and HEF. Viral DNA was detected in the nucleus of HEF 4 hours after infection, whereas in HUVEC viral DNA accumulated around the nucleus at 8 hours after infection (Fig. 2). The results of the ISH indicated that in a about $90 \%$ of HUVEC the virus can not reach the nucleus. The intriguing question arises why HCMV does not enter the nucleus in HUVEC. This was investigated further by 
electron microscopy and by using biochemical agents interfering with viral entry and/or transport.
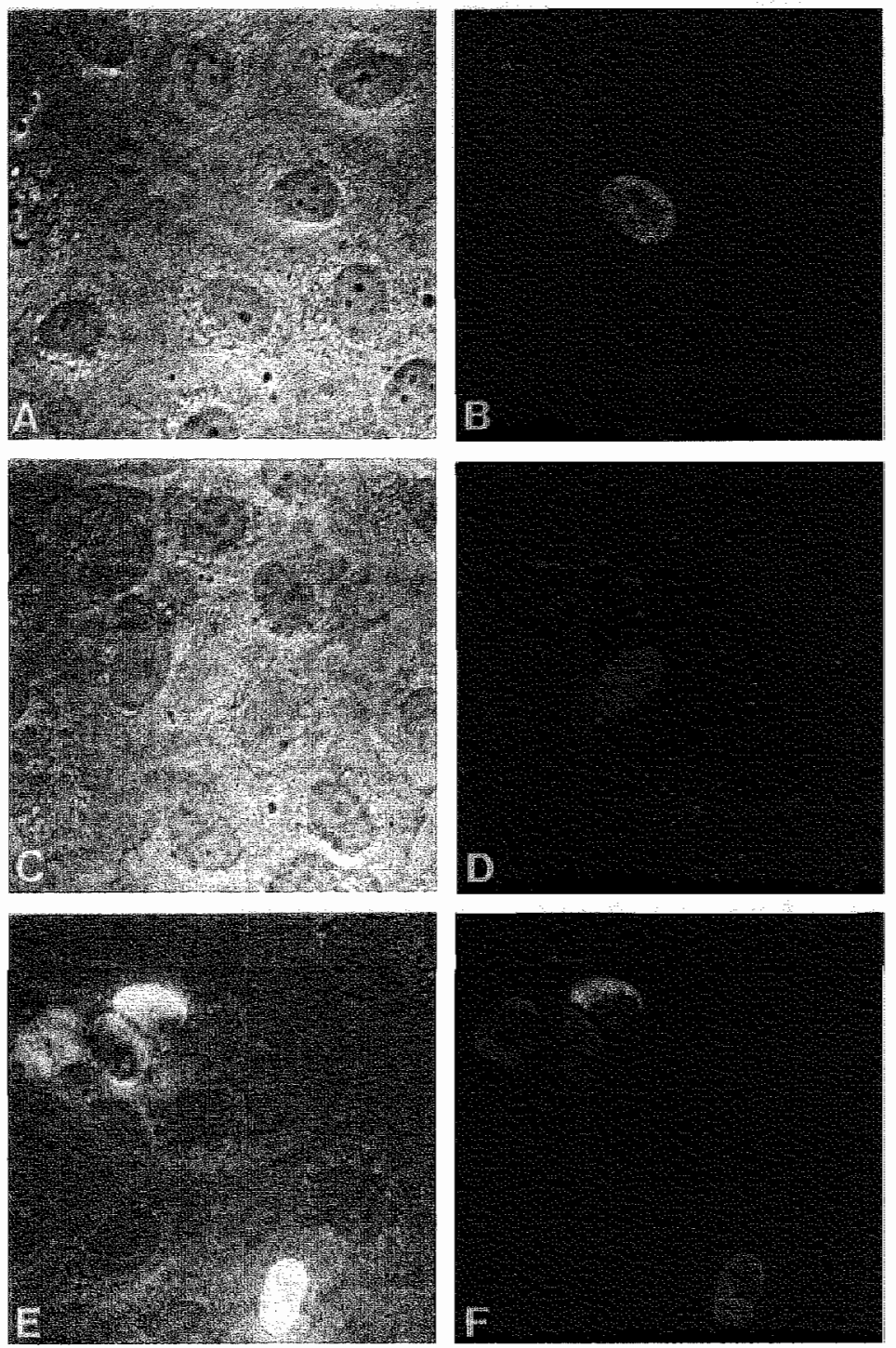

Fig. 1 Detection of HCMV IE and pp65 antigens by immunocytochemistry in HUVEC.

HUVEC were infected HCMV for different time periods; (A) Non-infected, (B) 6 hours, (C,D) 4 hours and $\left(E_{n} F\right) 16$ hours. The HCMV IE antigen (green) and the pp65 antigen (red) were detected with the use of specific monoclonal antibodies. Bars: $10 \mu \mathrm{m}$. 

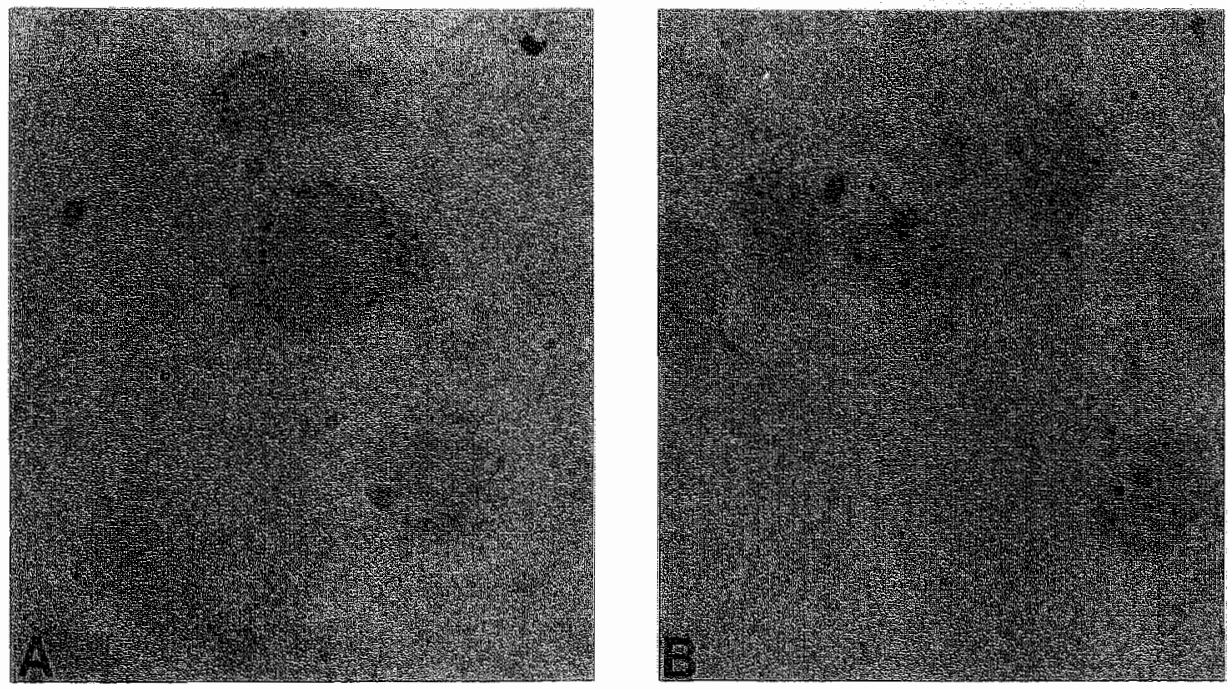

Fig. 2 Detection of HCMV in HUVEC and HEF 8 hours after infection.

HCMV biotin-labelled genomic probes were used for the hybridisation with HUVEC (A) and HEF (B) that were infected for 8 hours. HUVEC were infected with MOI 3 and HEF with MOI 2.

\section{EM analysis}

The entry of HCMV in HUVEC was investigated and compared. In general can envelope viruses enter cells by fusion with the plasma membrane or by uptake in vesicular structures through phagocytosis or endocytosis followed by a pHdependent fusion of the viral membrane with the endosome or lysosome membrane. To investigate the entry and transport of HCMV, electron microscopic observations were performed on HUVEC with cells that were infected for 15 min, 2 hours and 8 hours (Fig. 3). In HUVEC, virus particles and dense bodies were internalised within vacuoles The invaginations and vacuoles did not have an aspect of clathrin-coated pits or vesicles. No free virus particles and dense bodies were detected in the cytoplasm of HUVEC during the first 8 hours of infection. Partial degradation of the internalized viral particles and dense bodies was observed in the cytosol 8 hours after infection. The viral envelope was disrupted and dense bodies were not observed any more indicating that dense bodies are degraded. According to the electron microscopic observations small vesicular structures fuse with the vacuoles that contain virus particles. If this represents fusion of the virus containing vacuoles with lysosomes this could explain the partial degradation seen at 8 hours p.i. and the low permissiveness of AD169 for HUVEC. 

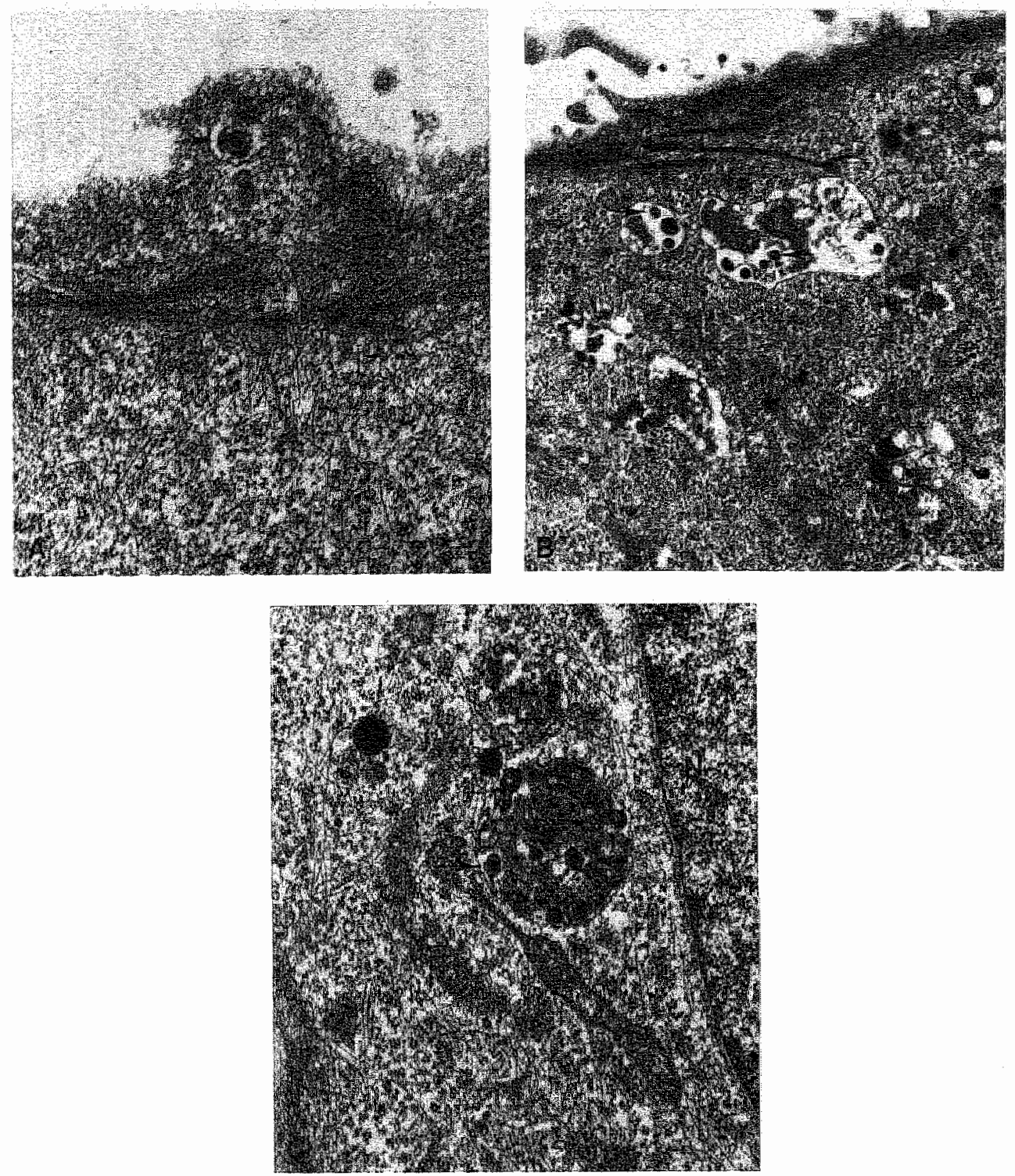

Fig. 3 Entry of HCMV virions (arrows) and dense bodies (DB) into HUVEC.

A 15 minutes after infection, virions and dense bodies are observed in the invaginations and vacuoles on the cell periphery. B Two hours after infection, numerous wirions, dense bodies, naked capsids and debris are present in large vacuoles. C Eight hours after infection, vacuoles containing dense material and damaged nucleopcapsids (arrows) are observed near the nucleus (N). 
These morphological findings in HUVEC demonstrate that HCMV enters HUVEC by a mechanism involving uptake into vesicular structures, and not by fusion of the viral envelope with the plasmamembrane as has been described for HEF (Compton et al., 1992).

\section{Biochemical experiments}

In order to investigate which mechanism is involved in the entry of HCMV in HUVEC and HEF, cells were treated with various concentrations of drugs inhibiting intracellular processes that may be involved in the viral entrance process. Some Iysosomotrophic drugs, such as ammoniumchloride and chloroquine, act primarily by inhibiting the acidification of the endosome (Shimura et al., 1987). Others, such as dansylcadaverine, may affect several pathways. As a weak base, dansylcadaverine is able to prevent acidification of endosomes. Dansylcadaverine is also a potent inhibitor of transglutaminase, and in this way it inhibits cross-linking of clathrin subunits and prevents clustering and internalisation of receptors associated with coated pits (Bass et al. 1995; Shimura et al., 1987). Cytochalasin B, like other cytochalasins, acts primarily by inhibition of F-actin polymerisation, which may play a role in endocytosis and cytoplasmic transport processes. The results showed that ammonium chloride, dansylcadaverine and chloroquine apparently do not influence the infection of HUVEC and HEF with HCMV (Fig. 4). These results indicate that it is unlikely that an $\mathrm{pH}$-dependent fusion of the virus with the endosomal membrane is important for the entry of the virus in both cell types. Dansylcadaverine does not seem to reproducibly affect the HCMV infection process in HUVEC. Overall the results indicate that dansylcadaverine does not influence the infectivity. Cytochalasin B. clearly decreases the number of HCMV IE positive cells in HUVEC to $54 \%$ of the control value, whereas this compound has no influence on the expression of IE antigen in HEF (Fig. 4). The inhibition of HCMV infection in HUVEC by cytochalasin $\mathrm{B}$ was concentration dependent (Fig. 5). Cytochalasin B concentrations above 5 ulM seem to effect the cellular viability as the number of the cells decreases when high concentrations of this compound is used; at $10 \mu \mathrm{M}$ the number of cells is decreased to $80 \%$ compared to the control. The difference in sensitivity for cytochalasin $B$ between HUVEC and HEF suggests that the entry andlor the intracellular transport of HCMV is different in these two cell types. To investigate if the biochemical agents have also an influence on transcription of HCMV genes the medium containing biochemical agents was removed and replaced by medium containing no agents 6 hours after infection. This gave the same results as 


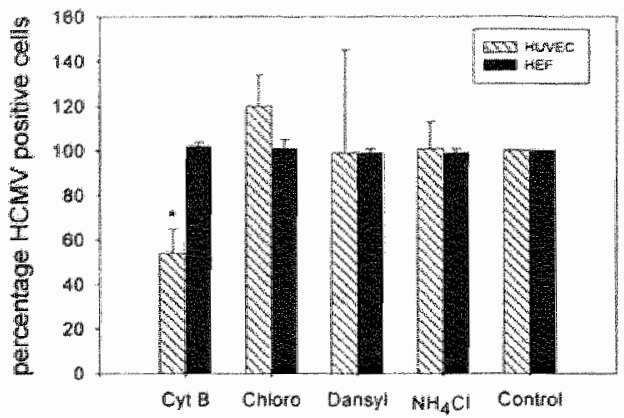

Fig. 4. Influence of biochemical agents on HCMV infectivily in HUVEC and HEF.

Celis were preincubated with $1 \mu \mathrm{M}$ cytochalasin $\mathrm{B}, 50 \mu \mathrm{M}$ chloroquine, $100 \mu \mathrm{M}$ dansylcadaverine or $25 \mathrm{mM}$ ammoniumchloride. Control is medium without any biochemical agent. After preincubation, the cells were infected with AD169 in medium with the biochemical agents (HUVEC MOI 3 and HEF MOI 0.1). One hour after the infection the medium was replaced with medium containing the biochemical agents. Cells were fixed 24 hours after infection. Data are represented as percentage of the control (Control 100\%). " significantly different from the controll.

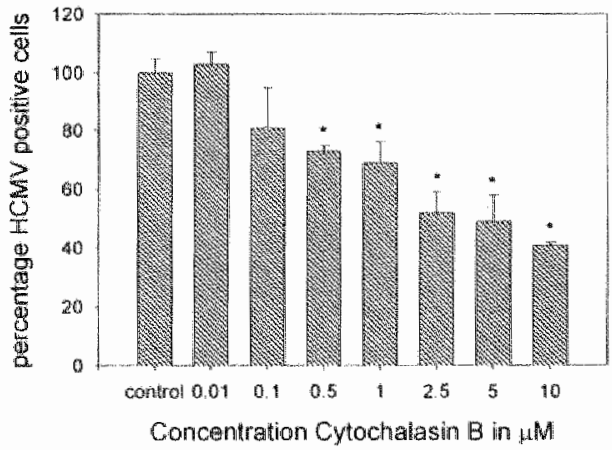

Fig. 5 Dose response curve of cytochalasin B on the HCMV infectivity on HUVEC.

HUVEC were preincubated with different concentrations of cytochalasin B. During the infection the cytochalasin $B$ was added (HUVEC MOI 3). After the infection the medium was replaced with medium containing different cytochalasin B concentrations. The cells were fixed 24 hours after infection and HCMV positive cells were detected with IE antibody. Data are represented as percentage of the control (control 100\%). " significantly different fram the control. 
Table 1 Influence of biochemical agents on the infection rate of AD169 in HUVEC and HEF

\begin{tabular}{|l|c|c|}
\hline & HUVEC & HEF \\
\hline Cytochalasin B & $61 \pm 3 \%$ & $99 \pm 3 \%$ \\
\hline Chloroquine & $106 \pm 15 \%$ & $89 \pm 6 \%$ \\
\hline Dansylcadaverin & $\mathrm{n} d$ & $99 \pm 4 \%$ \\
\hline Ammoniumchloride & $85 \pm 6 \%$ & $98 \pm 6 \%$ \\
\hline Control & $100 \%$ & $100 \%$ \\
\hline
\end{tabular}

"Cells were preincubated with biochemical agents for $1 \mathrm{hr}$ and subsequently infected with AD169 in the presence of the biochemical agents. After the infection, medium with biochemical agents was added. After $5 \mathrm{hr}$ the cells were washed and medium without biochemical agents was added. The cells were fixed $24 \mathrm{hr}$ after infection and stained with the use of anti-IE antibody

the experiments in which the biochemical agents were present during the whole experiment (24 hours) (Table 1). This observation suggests that the agents used probably do not influence the transcription of HCMV genes.

\section{DISCUSSION}

We investigated the HCMV cell tropism by monitoring viral penetration and replication in human endothelial cells in vitro using various techniques such as immunofluorescence staining for viral antigens, in situ hybridisation, electron microscopy and biochemical analysis of the early infection process. HUVEC display a low permissiveness for the HCMV strain AD169, whereas fibroblasts are highly permissive for this virus strain. Comparison of HUVEC and HEF could shed light on differences in of entrance and cytoplasmic transport of HCMV in both cell types which could explain the differences with respect to HCMV infectivity.

After viral entry, the virus has to be transported to the nucleus where viral transcription and replication is initiated. The ISH experiments showed accumulation of HCMV around the nucleus of HUVEC, whereas in HEF rapid nuclear entry occurred (Slobbe-van Drunen et al., 1998). The hypothesis therefore is that the transport of HCMV to the nucleus is hampered which could account for the low AD169 permissiveness of HUVEC. This hypothesis is also in agreement with the results obtained with pp65 and the immediate early protein. Only in HUVEC where pp65 can reach the nucleus the expression of the HCMV immediate early protein is detected. Indicating that only in these cells HCMV transcription can occur 
From the ultrastructural investigation of HCMV entry in endothelial cells, as assessed by electron microscopy, we observed that HCMV entered HUVEC by endocytosis or phagocytosis into vacuoles. The observed internalisation of AD169 in HUVEC is different from that in permissive human fibroblasts, where entry by $\mathrm{pH}$ independent fusion with the plasma membrane has been reported (Compton et al., 1992). Viral entry by endocytotic uptake into smooth walled vesicles and $\mathrm{pH}$ independent fusion has been reported also for EBV entry in B lymphocytes (Miller and Hutt-Fletcher, 1992; Nemerow and Cooper "1984). The early events in viral attachment of human CMV to endothelial cells and fibroblasts are apparently comparable as both show inhibition of the infection process by heparin, a compound interfering with the initial binding to cell surface heparan sulphate proteoglycans. After initial interaction HCMV subsequently binds to fibroblasts via $34 \mathrm{kDa}$ and 92.5 $\mathrm{kDa}$ cellular receptors that mediate viral fusion with the plasmamembrane (Taylor and Cooper, 1990; Adlish et all, 1990; Keay and Baldwin, 1992). It is not known whether endothelial cells or other cell types use the same receptors as fibroblasts for HCMV internalisation. It is possible that other cell types use other receptors mediating another penetration pathway. The EM studies revealed also that the vacuoles containing HCMV particles seem to be a degraded intracellularly in HUVEC

Furthermore, it was observed that the infectivity of HUVEC decreased through cytochalasin $B$, whereas this compound did not influence the infectivity of HEF. This indicates that the virus uptake or transport in HUVEC is probably a microfilamentdependent process. Lysosomotrophic agents such as ammonium chloride and chloroquine which inhibit pH-dependent fusion, and dansylcadaverine, which inhibits receptor mediated endocytosis, did not affect HCMV infection in HUVEC and HEF. This indicates that entry of AD169 is apparently not dependent on receptor-mediated clathrin coated endocytosis and $\mathrm{pH}$-dependent fusion with the endosome. Thus, the internalisation of AD169 in HUVEC seems to be $\mathrm{pH}$-independent, comparable to what is found for most herpesviruses.

Although it has been reported that cytochalasins inhibit internalisation pathways, this drug is not a specific inhibitor. It cannot be excluded that the inhibition of viral infection in HUVEC is due to some other effects of the drug on the HCMV infection process. Cytochalasin B may for instance also exert its action by altering the cytoplasmatic transport of virus to the nucleus in HUVEC, whereas it apparently does not have such an effect on HEF. This could indicate that there is a different transport mechanism for the virus in HUVEC and HEF, which would be in agreement with our ISH observations. The different effects obtained with cytochalasin B in 
HUVEC and HEF lend support to the hypothesis that the transport of the virus to the nucleus is different in both cell types.

Differences in the internalisation route of the virus in different cell types might reflect differences in the integration of membrane and cytoskeleton. The fact that endothelial cells are highly polarised, unlike fibroblast, may account for the difference in the viral import and transport pathways and their sensitivity to cytochalasin B. The presence of tight junctions in a confluent polarised monolayer may play a role in this respect. Involvement of tight junctions and cell polarisation in the viral infection process has been reported for HSV infection of epithelial MDCK cells (Hayashi, 1995) and for human CMV infection of polarised retinal pigment epithelial cells (Tugizov et al, 1996).

In summary, the observations on HCMV infection in HUVEC show that; A AD169 enters HUVEC by endocytotic uptake into vesicles and $\mathrm{pH}$-independent internalisation, a mechanism different from that reported for AD169 entry in HEF. B Transport of the virus through the cytoplasm in HUVEC differs from transport in HEF. In HEF CMV is readily transported into the nucleus, while in HUVEC the transport is hampered. Furthermore cytochalasin $B$, which also influences transport mechanisms in the cytoplasm, had no influence on the infectivity in HEF but decreases the infectivity in HUVEC. C Viral DNA accumulates around the nucleus in HUVEC and D The viral particles and dense bodies seem to be degraded in the cytosol of HUVEC. This all indicates that the virus becomes sequestered intracellularly in sites where uncoating is hampered and viral degradation promoted.

From these results it can be hypothesised that intracellular transport and sequestration may function as a defence mechanism of endothelial cells against CMV infection and that host cell specific factors involved in the internalisation pathway of cytomegalovirus contribute to viral cell tropism.

\section{REFERENCES}

Adlish, J.D., Lahijani, R.S. and St. Jeor, S.C. (1990) Identification of a pulative cell receptor for human cytomegalovirus. Virology $176(2): 337-45$

Bass, D.M., Baylor, M. Chen, C. and Upadhyayula, U. (1995) Dansylcadaverine and cytochalasin D enhance rotawirus infection of murine $L$ cells. Wirology 212(2): $429-437$

Bukrinskaya, A.G. (1982) Penetration of wiral genetic máterial into host celi. Adv. Virus Res. 27, 141 204

Compton, T., Nepomuceno, R.R. and Nowlin, D.M. (1992) Human cytomegalovirus prenetrates host cells by PH-independent fusion at the cell surface. Virology 191:387-395

Fleckenstein, B., Müller, 1. and Collins, J. (1982) Cloning the complete human cytomegalovirus genome in cosmids. Gene 18: $39-46$ 
Graham, R.C. and Karnoveky, M.J. (1968) The early stages of absorption of injected horseradish peroxidase in the proxinal tissue of the mouse kidney with structural cytochemistry by a new technique, 4. Histochem. Cytochem. 14: 281-302

Hayashi, K. (1995) Role of tight junctions of polarized epithelial MDCK cells in the replication of herpes simplex virus type 1. J. Med. virol $47(4): 323-329$

Hernandez, L.D., Hoffman, L.R., Wolfsberg. T.G. and White, J.M. (1996) Virus-cell and cell-cell fusion. Annu. Rov Cell Dev. Biol. 12:627-661

Keay, s. and Baldwin, B. (1992) The human fibroblast receptor for gp86 of human cytomegalovirus is a phosphorylated glycoprotein. $J$ Virol $66(8): 4834-8$

Lanzrein, M., Schlegel, A. and Kempf, C. (1994) Entry and uncoating of erveloped viruses. Brochem d. $302: 313-320$

Miller, N. and Hutt-Fletcher, L.M. (1992) Epstein-barr virus enters B cells and epithelial cells by different routes. J. Virol. 66(6): $3409-3414$

Myerson, D., Hackman, R.C., Nelson, J.A. and McDoughall, J.K. (1984) Widespread presence of histologically occult cytomegalovirus. Hum. Pathol. 15: 430-438

Nomerow, G.R. and Cooper, N.R. (9984) Early exents in the infection of human B lymphocytes by epstein-bart virus: the internalization process. Virology 132: 186-198

Shimura, $H_{2}$, Umeno, $Y_{\text {. }}$ and Kimura, G. (1987) Effects of inhibitors of the cytoplasmic structures and functions on the early phase of infection of cultured cells with simian virus 40 . Virology 158(1): $34-43$

Slobbe-van Drunen, M.E.P., Hendrickx, A.T.M., Vosisen, R.C.R.M., Speel, E.J.M., van DamMieras, M.C.E. and Bruggeman, C.A. (1998) Nuclear import as a barrier for infection of endothelial cells with human cytomegalowirus. Virus Res. in press

Slobbe-van Drunen, M.E.P., Vossen, R.C.R.M., Couwenlberg, F.M.D., Hulsbosch, M.M., Heemskerk, J.W.M., wan Dam-Mieras, M.C.E. and Bruggeman, C.A. (1997) Activation of protein kinase $C$ enhances the infection of endothelial cells by cytomegalovirus. Virus Res. $48,207-213$

Speel, E.J.M., Jansen, M.P.H.M., Ramaekers, F.C.S. and Hopman, A.H.N. (1994) A novel triplecolor detection procedure for brightfield microscopy, combinding in situ hybridisation with immunocytochemestry. Histochem. Cytochem. 42: 1299-1307

Stals, F.S., Bosman, F., van Boven, C.P. and Bruggeman, C.A. (1990) An animal model for therapeutic intervention studies of CMV infection in the immunacompromised hast. Arch. Virol. 114(11-2): 91-107

Taylor, H.P. and Cooper, N.R. (1990) The human cytomegalovirus receptor on fibroblasts is a $30-$ kilodalton membrane protein. J. Virol 64(6): 2484-90

Tugizov, S., Maidji, E. and Pereira, L. (1996) Role of apical and basolateral membranes in replication of human cytomegalovirus in polarized retinal pigment epithelial cells. 1 . Gen. Virol $77(\mathrm{Pt} 1): 61-74$

Tumilowicz, J.J. (1990) Characteristics of human smooth muscle cell cultures infected with cytomegalovirus In Vitro Cell. Dev. Biol. 26: 1144-1150

Vossen, R.C.R.M., Persoons, M.C.J., Slobbe-van Drunen, M.E.P., Bruggeman, C.A. and wan Dam-Mieras, M.C.E. (1997) Intracellular thiol redox status affects cytomegalovirus infection in vascular colls. Virus Res. 48:173-183

Vossen, R.C.R.M., van Dam-Mlieras, M.C.E. and Bruggeman, C.A. (1996) Cytomegalovirus infection and vessel wall pathology. Hienirology 39: 213-221

White, J.M. (1990) Viral and cellular membrane fusion proteins. Annu. Rev. Physiol. 52 675-697

Wittels, M. and Spear, P.G. (1991) Penetration of cells by herpes simplex virus does not require a low pH-dependent endocytic pathway. Virus Res. 18(2-3): 271-90 


\section{SUMMARY AND GENERAL DISCUSSION}




\section{SUMMARY AND GENERAL DISCUSSION}

Human cytomegalovirus (HCMV) infection appears to be involved in several vascular diseases, such as transplantation associated arteriosclerosis, restenosis following coronary angioplasty and atherosclerosis. In this thesis, some aspects of the mechanisms by which this may occur have been studied in vitro using endothelial cells and fibroblasts as a model system. Endothellall cells were chosen because of their strategic location between the blood circulation and the surrounding tissue. The endothelial cell responses were compared with the responses of fibroblasts to HCMV infection

Since diseases in which CMV possibly is involved are often associated with a (pro-) thrombotic state of the vascular wall we first studied the influence of two HCMV strains, AD169 (propagated on fibroblasts) and VHL-E (endothelial cell adapted virus), on membrane perturbation and procoagulant activity on human umbilical vein endothelial cells (HUVEC), microvascular endothelial cells (MVEC) and human embryonal fibroblasts (HEF) (Chapter 2). Membrane perturbation was detected in both types of endothelial cells with both virus strains but not in fibroblasts. Membrane effects were only found at $37^{\circ} \mathrm{C}$ and not at $4^{\circ} \mathrm{C}$, which could mean that not only the binding to, but also the penetration of the virus into the endothelial cell is necessary to induce this effect. The virus strain adapted to endothelial cells, which yields a much higher infection level in HUVEC than AD169, failed to show a higher degree of membrane perturbation. This may indicate that the level of productive infection is not the determining factor for the induction of membrane perturbation. Fibroblasts do not play a central role in establishing the procoagulant / anticoagulant balance of the vascular wall as endothelial cells do and the differences in the CMVinduced procoagulant response between these two cell types might very well reflect this. It can be assumed that membrane perturbation facilitates the interaction of coagulation factors which makes the surface of the vessel more procoagulant, and may lead to a (pre) thrombotic state, one of the phenomena observed in arteriosclerosis.

It has previously been described that molecular changes that render endothelial cells more procoagulant in response to a HCMV infection include secretion of the antihaemophilic factor VIII carrier protein, von Willebrand factor (Bruggeman et al., 1988) and tissue factor (Vercellotti et al. 1997) and rearrangement of the cell membrane phospholipids (Van Dam-Mieras et all. 1992). All of these responses could play a role in the development of vascular pathology associated with CMV disease. Furthermore, only a significant association between HCMV and atherosclerosis was found in individuals with high levels of lipoprotein(a) and 
fibrinogen, indicating that HCMV infection alone may not be enough to cause atherosclerosis (Nieto et al., 1997). Therefore it is speculated that HCMV can enhance vascular disease as a co-factor, which is corroborated by our results.

Because there is a remarkable heterogeneity among endothelial cells, possibly due to the local conditions under which the endothelial cells differentiate (Garlanda and Dejana, 1997), it was investigated whether the endothelial cells from macro-and micro-vascular origin would respond differently to CMV infection. These experiments (Chapter 2) show that microvascular endothelium is more responsive to infection with HCMV than macrovascular endothelium with respect to membrane perturbation. This indicates that also in the in vivo situation responses to HCMV infection of endothelial cells depend on the location of these cells in the vascular system.

In the studies described in Chapter 3 we investigated whether the CMV-induced procoagulant activity and/or membrane perturbation was caused by a direct effect of the virus or by an indirect effect. We demonstrated that the effects must be due to an indirect effect since the supernatant, containing no infective virus, could induce both effects. It seems that the infection of permissive cells such as fibroblasts by CMV induces the production and secretion of soluble factors which are responsible for the phenomena observed in HUVEC. It has already been shown by others that fibroblasts, infected with HCMV, release cytokines such as interleukin-8 (IL-8) and RANTES (Craigen et al., 1997, Michelson et al., 1997). We therefore investigated if IL-1, tumour necrosis factor (TNF) and IL-8 could induce procoagulant activity and cause membrane perturbation in endothelial cells. We found that indeed all of these cytokines were able to evoke both responses. Therefore, we conclude that the virus probably induces procoagulant activity and causes membrane perturbation indirectly via the release of cytokines or other factors. Such an involvement of cytokines in virus induced vascular pathology is indeed what can be expected.

It has been reported, however, that purified HCMV virus per se can also evoke a procoagulant response. The purified HCMV constitutively displays phosphatidylserine (PS) and thereby constitutes a procoagulant surface on which coagulation factors interact to form a prothrombinase complex which generates thrombin (Pryzdial and Wright, 1994). The HCMV envelope also contains tissue factor which contributes to the procoagulant activity (Sutherland et al., 1997). In this context we should of course realise that virus envelopes are complex structures in which the phospholipids are derived exclusively from the host cell, whereas the proteins are encoded by both the host and virus genome. A tissue factor homologue is not encoded by the HCMV genome and, therefore, must be acquired along with the procoagulant phospholipids from the host. As viral infection will result in cellular activation we can postulate that the HCMV surface will differ from that of quiescent 
cells lining the vascular wall. The inner lining of the vascular wall normally is not in a procoagulant state, but such a state can be reached by activation. A control mechanism restricts the expression of procoagulant phospholipids to areas of vascular injury / activation (Bevers et al., 1983). As HCMV is released from activated cells it can be assumed that the envelope of the virus reflects the surface of these activated cells, in their procoagulant state. It was found, however, that a preparation of dense bodies and non-infectious particles can also induce procoagulant activity. This means that a productive infection of the cells would not be necessary to induce procoagulant activity, since these particles are not capable of productively infecting cells. The question of course remains whether in vivo or in vitro the concentration of the viral particles reaches a level locally sufficient to induce a procoagulant response, without any other activation of the cells. In vivo will this probably not occur since such local virus concentrations will mainly occur intracellularly and are not found extratracellularly. Our in vitro results show that no procoagulant activity can be detected when the penetration of the virus is inhibited by the incubation at $4^{\circ} \mathrm{C}$ during infection, which points to cellular activation in the establishment of the procoagulant response.

A procoagulant response induced by HCMV-infection can be seen as belonging to the defence strategy of the host against viral infection. Coagulation then could be perceived as supporting an inflammatory response.

Inflammatory responses, which are believed to play a crucial role in the onset of atherosclerotic vascular diseases (Ross, 1993) " develop via the adhesion of leukocytes to the endothelium. Our group and others have found a release of $\mathrm{LL}-8$, a potent neutrophil chemoattractant with monocyte chemotactic activity, in HCMV infected fibroblasts (Craigen et al., 1997) In the study described in Chapter 3 we describe the release of IL- 8 by HCMV infected endothelial cells in vitro. The fact that HCMV induces an increase in the adherence of polymorphonuclear cells and monocytes (Span et al., 1991a, Span et al., 1991b) on endothelial cells, could be caused by the increase in expression of adhesion molecules like ICAM and ELAM and with the release of chemokines like IL- 8 by infected endothelial cells.

HCMV infection of endothelial cells leads to quite distinctive effects, in spite of the fact that the productive infection level of HCMV is very low in these cells. The infection level of the HCMV laboratory strain AD169 in HUVEC is between 5 and $10 \%$. In Chapter 4 , we describe our study on the effect of activation of cellular signal transduction pathways on the productive HCMV infection of HUVEC. We found that the phorbolester phorbol 12-myristate 13-acetate (PMA) increases this infection level, indicates that activated endothelial cells are more permissive for HCMV than quiescent cells. From our observation we conclude that, protein kinase $C$ seems to 
be a main factor involved in the PMA-stimulated increase in HCMV infection. Thus, from the results described in Chapters 3 and 4 it can be concluded that on the one hand CMV infection results in activation of endothelial cells, whereas on the other hand activation of endothelial cells can lead to an increase of HCMV infectivity.

During injury endothelial cells are activated by proinflammatory cytokines, like $\| \mathrm{L}-1$ and TNF and by reactive oxygen intermediates. The transcription factor NF-kB plays an important role in the induction of genes during inflammatory responses. Activation of this transcription factor is triggered by a wide variety of proinflammatory peptides, cytokines, PMA as well as reactive oxygen intermediates like $\mathrm{H}_{2} \mathrm{O}_{2}$ (Munroe et al.

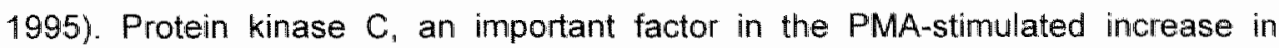
HCMV infection in endothelial cells, has been shown to activate NF-kB (Ghosh and Baltimore, 1990), which itself stimulates transcription of HCMV (Löser et al., 1998, Prösch et al., 1995). Therefore, it can be hypothesised that the increase in HCMV infection level in endothelial cells after PMA stimulation is due to activation of $N F-k B$, which enhances the transcription of HCMV genes. However, other mechanisms such as phosphorylation of receptors required for HCMV entry like the $92.5 \mathrm{kDa}$ cell membrane receptor for HCMV glycoprotein $\mathrm{gH}_{\text {" }}$ and the host cell annexin $\mathrm{II}$, which can bind HCMV gB, may also be involved (Jost and Gerke, 1996, Keay and Baldwin, 1996, Pietropaolo and Compton, 1997).

Tissue injury causes cellular inflammatory responses during which T-cell, monocytes and neutrophils are recruited to the site of injury. The generation and release of reactive oxygen intermediates play a role in such processes. The generation and release of reactive oxygen intermediates may enhance HCMV infection in endothelial cells and smooth muscle cells via the activation of NF-kB (Vossen ell al., 1997. Scholz et al, 1996, Speir et al., 1996). The pro-inflammatory cytokine TNF is also able to activate $N F-\kappa B$. Thus, injury of endothelial cells may be capable of activating HCMV expression by the activation of NF-KB.

HCMV infection, on the other hand, influences signal transduction pathways which have an effect on PKC activation (Nokta el al, 1987, Valyi-Nagy et al., 1988). Activation of PKC induces, among others, the expression of adhesion moleculles on endothelial cells and is involved in the regulation of the endothelial permeability (Lane et al., 1989, Mason et al, 1997, Siflinger-Birnboim and Malik, 1996, Stasek and Garcia, 1992). This might lead to recruitment of inflammatory cells like monocytes and neutrophils to the site of infection followed by tissue injury. 


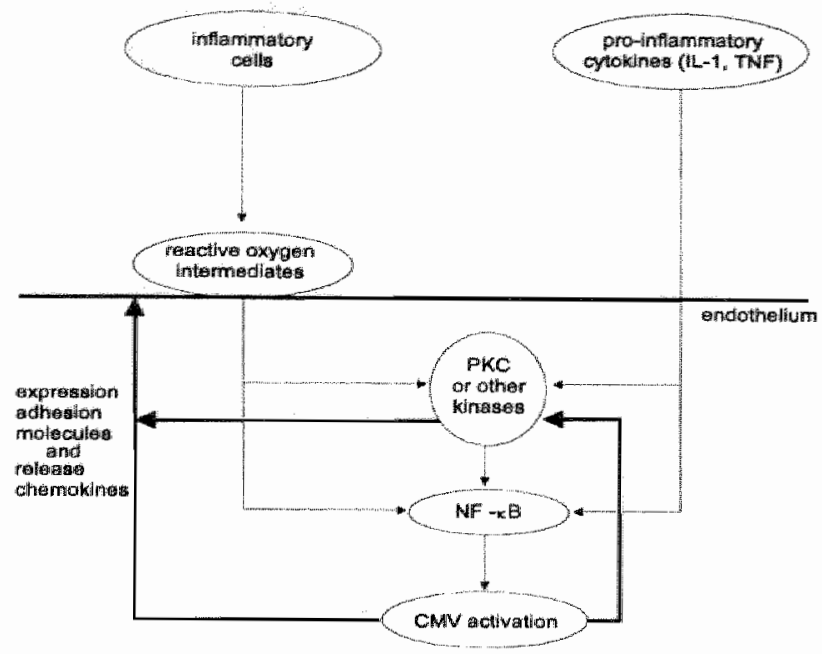

Fig. 1 Schematic representation of shared mechanisms activated by vascular injury and HCMV infection

Inflammatory mediators such as IL-1 and TNF also induce the expression of adhesion molecules, possibly through activation of signal transduction pathways such as the PKC pathway and by activating NF-kB (Lane et al., 1990).

In conclusion, both vascular injury and HCMV infection activate the same defence and activation processes, namely the expression of adhesion molecules and the induction of procoagulant activity. Due to this phenomenon it is difficult to distinguish between association and causation as well as between the primary and secondary effect of this virus on vascular wall pathology. Furthermore, it should be kept in mind that the experiments were done in vitro and that the a straightforward extrapolation of results of in vitro experiments to the in vivo situation is never allowed.

Endothelial cells are infected only to a limited extent whereas fibroblasts are fully permissive. The mechanisms responsible for this difference have not been elucidated yet. In the last two Chapters of this thesis (Chapters 5 and 6) experiments on the differences between the early stages of HCMV infection in endothelial cells and fibroblasts are described. Endothelial cells are infected to only a limited extent whereas fibroblasts are fully permissive. We found that the expression of the IE antigen started later after infection in the low permissive 
HUVEC than in the fully permissive HEF. This can be explained by the fact that transport of the virus to the nucleus, where viral transcription takes place, is slower in HUVEC than in HEF. In this respect the observation that viral DNA accumulates around the nucleus of HUVEC but not around those of HEF was most interesting. The entrance into the endothelial cells does not seem to be hampered, since viral DNA is detected in the cytoplasm of nearly all endothelial cells. These findings indicate that the virus cannot reach the nucleus of endothelial cells as efficiently as that of fibroblasts, which would lead to the low permissiveness of HUVEC for the HCMV strain AD169.

The actual mechanism of virus entry into the host cell could also contribute to the differences in virus infections of different cell types. It can be concluded from electronmicroscopic studies that HCMV enters both HUVEC and HEF but that the mechanism of entrance in HUVEC differs from that in HEF. The entry of HCMV in HUVEC appears to occur through endocytosis, while in HEF the virus enters the cell through fusion. The observation that, as a result of the entrance procedure, in HUVEC the virus is enclosed in vesicular structures while in HEF the virus occurs free in the cytoplasm, could implicate that the transport mechanism of the virus to the nucleus is different between the two cells types. The fact that cytochalasin B, an inhibitor of the F-actin polymerisation which is involved in cytoplasmatic transport processes, only influences the infectivity of HCMV in HUVEC and not in HEF could lend support to this hypothesis.

Another phenomenon contributing to the low permissiveness of HUVEC for the HCMV strain AD169 is degradation of the virus within the vesicular structures after viral entrance. Eight hours after infection the vesicular structures are degraded and no viral particles can be identified in the cytoplasm, which indicates that degradation of the virus in HUVEC may be a mechanism to protect the cell against HCMV infection. On the other hand, disassembly of the virus is necessary for the viral DNA transport into the nucleus and it is difficult to distinguish between viral degradation and the disassembly of the virus. This means that it will be necessary to investigate the enzymes involved in the degradation of the vesicle and the viral particles. The question that remains is why the viral entry is different in HUVEC and HEF.

Viral entry of the cell by endocytosis, the inefficient uptake of viral DNA by the nucleus as well as the presumed degradation of HCMV in HUVEC are interesting aspects of the interaction between virus and host. We can raise the question whether this sequence of events is orchestrated by the host cell or rather reflects a property of the virus. In this respect it would be interesting to repeat the experiments using an endothelial adapted HCMV virus strain in HUVEC, and to compare the 
results obtained with that strain to our present results obtained with the AD169 strain.

Due to the crucial location of endothelial cells, it is attractive to assume that most of the cells protect themselves against productive CMV infection, and as a consequence the tissue lying behind this protective layer. However, even a low CMV infection grade of the endothelium can induce several responses like membrane perturbation, generation of procoagulant activity. release of cytokines and the expression of adhesion molecules, which implicates that CMV could play a role as a co-factor in various vascullar diseases. The question whether CMV infection of endothelial cells and subsequent cellular activation is the primary cause of vasculopathy or if it is a co-factor in a multicausal process still remains.

\section{References}

Bevers, E.M., Comfurius, P. and Zwaal, R.F. (1983) Changes in membrane phospholipid distribution during platelet activation. Biochem. Biophys. Acta 736: 57-66

Bruggeman, C.A., Debie, W.H.M., Muller, A.D., Schutte, B. and van Dam-Mieras, M.C.E. (1988) Cytomegalowirus alters the von Willebrand factor content of human endothelial cells. Thromb Hemost 59: 264

Craigen, J.L., Yong, K.L., Jordan, N.J., Maccormac, L.P., Westwick, J. and Akabar, A.N. (1997) Human cytomegalovirus infection up-regulates interleukin-8 gene expression and stimulates neutrophil transendothelial migration. Immunology 92: 138-145

Garlanda, C. and Dejana, E. (1997) Heterogeneity of endothelial cells. Specific markers. Arterioscler. Thromb Vasc. Biol. 17: 1193-1202

Ghosh, S. and Baltimore, D. (1990) Activation in vitro of NF- B by phosphorylation of its inhibitor IKB. Nature 334: 678-682

Jost, M. and Gerke, V. (1996) Mapping of a regulatory important site for protein kinase C phosphorylation in the N-terminal domain of annexin II. Biochem. Biophys. Acta 11(1313): $283-289$

Keay, S. and Baldwin, B.R. (4996) Evidence for the role of cell protein phosphorylation in thuman cytomegalowirus/host cell fusion. J Gen. Wirol 77: 2597-2604

Lane, T.A. Lamkin, G.E. and Wancowicz, E. (1989) Modulation of endothelial cell expression of intercellular adhesion molecule $\mathbb{1}$ by protein kinase $\mathrm{C}$ activation. Biochem. Biophys. Res. Comm: 161: $945-952$

Lane, T.A., Lamkin, G.E. and Wancewicz, E.V. (1990) Protein kinase $C$ inhibitors block the enhanced expression of intraceliular adhesion molecule- 1 on endothelial cells activated by interleukin-1 lipopolysacharide and tumor necrosis factor. Biochem. Biophys. Res. Cornm. 172: $1273-1281$

Lóser, P., Jennings, G.S., Strauss, M. and Sandig, V. (1998) Reactivation of the previously silenced cytomegalovirus major immediate-early promoter in the mouse liver: involvement of NFKB. I Virol 72: $180-190$

Mason, J.C., Yarwood, H., Sugars, K. and Haskard, D.O. (1997) Huamn umbilical vein and dermal imicrovascular endothelial cells show heterogeneity in response to PKC activation. Am. $J$. Physiol. 273 : c1233-c1240

Michelson, S., Dal Monte, P., Zipeto, D., Bodaghi, B., Laurent, L., Oberlin, E., ArenzanaSeisdedos, F., Virelizier, J.-L. and Landini, M.P. (1997) Modulation of RANTES production by human cytomegalovirus infection of fibroblasts. J. Virol. 71: 6495-6500

Munroe, D.G., Wang, E.Y., Maclntyre, J.P., Tam, S.S.C., Lee, D.H.S., Taylor, G.R., Zhou, L., Plante, R.K., Kazmi, S.M.l., Bäuerle, P.A. and Lau, C.Y. (1995) Novel intracellular signaling function of prostaglandin $\mathrm{H}$ synthase- 1 in $\mathrm{NF}$ - B activation. J. Inflammation 45 . 260268 
Nieto, F.J., Sorlie, P., Comstock, G.W., K., W., Adam, E., Melnick, J.L. and Szkllo, M. (1997) Cytomegalovirus infection, lipoprotein(a), and hypercoagulability: An atherogenic link? Arterioscler. Thromb. Vasc. Biol. 17: 1780-1785

Nokta, M., Eaton, D., O.S., S. and Albrecht, T. (4987) Ca ${ }^{2+}$ responses in eytomegalowirus-infected fibroblasts of human origin. Virology 157:259-267

Pietropaolo, R.L. and Compton, T. (1997) Direct interaction between human cytomegalovirus glycoprotein B and cellular annexin 11. \&. Virol. 71: $9803-9807$

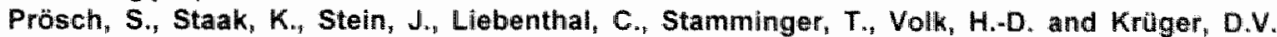
(1995) Stimulation of the human cytomegalovirus IE enhancer/promoter in HL-60 cells by TNF alpha is mediated via induction of NF-KB. Virology 208: 197-206

Pryzdial, E.L.G. and Wright, J.F. (1994) Prothrombinase assembly on an enveloped wirus: evidence that the cytomegalovirus surface contains procoagulant phospholipid. Blood 84(11): 3749 3757

Scholz, M., Cinatl, J., Gross, V., Vogel, J.-U., R.A., B., Freisleben, H.J., Markus, B.H. and Doerp, H.W. (1996) Impact of oxidative stress on human cytomegalowirus replication and on cytokine mediated stimulation of endothelial cells. Transplantation 61 : 1763-1770

Siflinger-Birnboim, A. and Malik, A.B. (1996) Regulation of endothelial permeability by second messengers New-Horiz. 4:87-98

Span, A.H., Mullers, W., Miltenburg, A.M. and Bruggeman, C.A. (1991a) Cytomegalovirus induced PMN adherence in relation to an ELAM-1 antigen present on infected ondothelial cell monolayers. Immunology 72 (3) 355-60

Span, A.H., van Dam Mieras, M.C. Mullers, W. Endert, ل., Muller, A.D. and Bruggeman, C.A. (1991b) The effect of virus infection on the adherence of leukocytes or platelets to endothelial cells. Eur. J. Clin. Invest. 21(3): 331-8

Speir, E., Shibutani, T., Yu, Z.-X., Ferrans, V. and Epstein, S.E. (1996) Role of reactive oxygen intermediates in cytomegalovirus gene expression and in the response of human smooth muscle cell to viral infection. Circ Res 79: 1143-1152

Stasek, J.E. and Garcia, J.G.N. (1992) The role of protein kinase C in Alpha-thrombin-mediated endothelial cell activation. Seminars in Thrombosis and Hemostasis 18: 117-125

Sutherland, M.R., Raynor, C.M., Leenknegt, H., Wright, J.F. and Pryzdlal, E.L.G. (1997) Coagulation initated on herpesviruses. Proc. Nall. Acad SCi. USA 94: 13510-13514

Valyi-Nagy, T., Bandi, Z., Boldogh, I. and Albrecht, T. (1988) Hydrolysis of inositol lipids: an early signal of human cytomegalovirus infection. Arch. Virol. 101: 199-207

Van Dam-Mieras, M.C.E., Muller, A.D., van Hinsbergh, V.W.M., Mullers, W.J.H.A., Bomans, P.H.H. and Bruggeman, C.A. (1992) The procoagulant response of cytomegalovirus infected endothelial cells. Thromb. Haemost 68: 364

Vercellotti, G.M., Kovacs, A., Key, N.S., Dandelet, L.A. and Jacob, H.S. (1997) Human cytomegalovirus infection of endothelial cells induces tissue factor expression. Thromb Heamost suppl, 203

Vossen, R.C.R.M., Persoons, M.C.J., Slobbe-van Drunen, M.E.p., Bruggeman, C.A. and van Dam-Mieras, M.C.E. (1997) Intracelular thiol redox status affects cytomegalovirus infection of vascular cells. Wirus Res. $48: 173-183$ 


\section{SAMENVATTING}




\section{SAMENVATTING}

Humaan cytomegalovirus (HCMV) lijkt betrokken te zijn bij verschillende vasculaire aandoeningen, zoals transplantatie geassocieerde arteriosclerosis, restenosis en atherosclerosis. Dit proefschrift beschrijft enkele mogelijke mechanismen waardoor de infectie van endotheel cellen door HCMV kan bijdragen aan deze vaatziekten. In hoofdstuk 2 wordt de invloed van HCMV op endotheelcellen met betrekking tot membraanverstoringen en stolling, beide belangrijke mechanismen bij het ontstaan van vaataandoeningen, nader bestudeerd. Endotheelcellen, geïsoleerd uit de microcirculatie (MVEC) en macrocirculatie (HUVEC), vertonen een duidelijke dosisafhankelijke membraanverstoring kort na infectie met HCMV. De membraanverstoring wordt alleen gevonden als de endotheelcellen geïnfecteerd worden bij $37^{\circ} \mathrm{C}$, wat een aanwijzing is dat binding van het virus aan de celmembraan alleen niet voldoende is om dit effect te veroorzaken. Het virus type, AD169 (een HCMV laboratorium stam welke gekweekt wordt op humane embryonale fibroblasten (HEF)) en VHL-E (een endotheel geadapteerde HCMV stam), waarmee het endotheel geïnfecteerd wordt is niet van invloed op de mate van membraanverstoring. Daarentegen is er wel een duidelijk verschil voor wat betreft de mate van infectie in endotheelcellen in vitro: AD169 geeft een lage infectiegraad in endotheelcellen, terwijl VHL-E een hoge infectiegraad geeft. Fibroblasten, die in vitro ook goed geïnfecteerd worden door HCMV vertonen geen significante membraanverstoring. Dit duidt erop dat de mate van infectie niet de bepalend factor is die de membraanverstoring veroorzaakt.

De vraag is of de membraanverstoring en stolling gevonden bij HCMV geïnfecteerde humane endotheel wordt door een indirekt of een direkt effect van het virus. Uit het feit dat het supernatant van het virus preparaat, waaruit het virus verwijderd is door middel van ultracentrifugatie, ook in staat is om stolling en membraanverstoringen te veroorzaken in tegenstelling tot het kweeksupernatant van ongeinfecteerde fibroblasten, geeft aan dat mogelijk een indirect effect van het virus verantwoordelijk is voor deze fenomenen (Hoofdstuk 3). Het lijkt dus aannemelijk dat fibroblasten geinfecteerd met HCMV naast het afgeven van virus ook substanties afgeven aan het kweeksupernatant, die verantwoordelijk kunnen zijn voor de geobserveerde effecten in endotheelcellen. Aangezien reeds bekend was dat onder andere cytokines door geïnfecteerde fibroblasten worden afgegeven, is de invloed van verschillende cytokines, zoals interleukine-1 (IL-1), IL-8 en tumor necrose factor (TNF), op de membraanverstoring en stolling onderzocht. Al deze cytokines, die ook tijdens een infectie in vivo geproduceerd worden, waren in staat om stolling en membraanverstoringen te induceren. Uit al deze gegevens kan geconcludeerd 
worden dat de geïnduceerde stolling en membraanverstoringen indirect door het virus geïnduceerd worden, en dat de afgifte van cytokines of andere onbekende factoren na infectie van HCMV hiervoor verantwoordelijk kunnen zijn. Deze hypothese wordt versterkt doordat in Hoofdstuk 3 verder is aangetoond dat HCMV de afgifte van IL-8 kan induceren in HUVEC.

IL-8 is een chemoattractant voor polymorfonucleaire cellen en monocyten. Al eerder is aangetoond dat HCMV de expressie van adhesiemoleculen verhoogt en dat er na infectie een verhoogde hechting plaatswindt van polymorfonucleaire cellen en monocyten aan endotheelcellen. De verhoging van de hoeveelheid hechtende cellen is waarschijnlijk het gevolg van de verhoging van de expressie van de adhesiemoleculen en de afgifte van chemokines zaals IL-8. Immunologische processen zoals ontstekingen worden onder andere in gang gezet door de hechting van leukocyten op het endotheel. Daarom kan gespeculeerd worden dat HCMV in staat is om immunologische processen te induceren die uiteindelijk kunnen leiden tot verschillende vasculaire aandoeningen.

Ondanks de duidelijke reactie van HUVEC op de infectie van de HCMV stam AD169 is de mate waarin deze cellen geïnfecteerd worden zeer laag: tussen de 5 en 10\% van de endotheelcellen kunnen geïnfecteerd worden door HCMV. In Hoofdstuk 4 is beschreven dat de forbol ester forbol 12-myristate-13-acetaat (PMA) in staat is de mate van infectie in endotheelcellen significant te verhogen. Door gebruik te maken van diverse protein kinase activatoren en remmers is aangetoond dat de belangrijkste factor betrokken bij de door PMA verhoogde infectie protein kinase $C$ (PKC) is. PKC is een enzym dat eiwitten fosforyleert en zo betrokken is bij vele cellulaire processen, zoals de activatie van de transcriptie factor NF-kB en de expressie van adhesiemoleculen. In geactiveerde cellen is de PKC activiteit vaak verhoogd. Dit impliceert dat HCMV in staat is om geactiveerde endotheelcellen beter te infecteren dan cellen in rust en dat het virus gebruikt maakt van basale cellulaire processen.

Ondanks het feit dat PMA de infectie kan verhogen in endotheelcellen is het aantal geïnfecteerde cellen nog steeds een veel lager dan bij fibroblasten, waar bijna alle cellen geïnfecteerd worden. In de Hoofdstukken 5 en 6 van dit proefschrift is daarom het infectieproces van de HCMV stam AD169 in HUVEC bestudeerd en vergeleken met het infectieproces van deze HCMV stam in HEF. Hierbij zijn enkele duidelijke verschillen aangetroffen tussen het infectieproces in deze endotheelcellen en fibroblasten. A De expressie van de vroege (immediate early) en late (late) virale antigenen is vertraagd in endotheelcellen ten opzichte van fibroblasten. B Met behulp van in situ hybridisatie is een ophoping van viraal DNA geconstateerd rond de kernen van endotheelcellen 8 uur na infectie terwijl op dit zelfde tijdstip viraal 
DNA in de kernen van de fibroblasten reeds aanwezig is. $c$ Uit electronenmicroscopische opnamen van HCMV geinfecteerde endotheelcellen en fibroblasten bleek dat het mechanisme waarmee het virus de cel binnenkomt verschillend is in beide celtypen. Het virus komt via endocytosis endotheel cellen binnen terwijl het via fusie met de celmembraan fibroblasten binnen komt. Doordat het virus in endotheelcellen via endocytosis binnen komt bevindt het virus zich in deze cellen in vacuoles die afgebroken worden in het cytoplasma. Of het wirus ook geheel afgebroken wordt, dus zowel op eiwit niveau als op DNA niveau, is nog niet duidelijk. Echter een normale virale structuur van het virus is 8 uur na infectie niet meer aantoonbaar met behulp van de electronenmicroscopie. D Cytochalasin $B$, een remmer van de Factine polymerisatie, remt alleen de infectie in endotheelcellen, wat aangeeft dat intacte actinefilamenten nodig zijn.

Deze verschillen tussen HUVEC en HEF geven aan dat de binnenkomst en het transport van AD 169 in HUVEC geheel anders is dan in HEF. De ophoping van het viralle DNA en de afbraak vain het virus in deze endotheelcellen zouden een verklaring kunnen zijn dat deze cellen slecht infecteerbaar zijn door AD169. Of deze verschillen veroorzaakt worden door verschillen tussen beide celtypen of een inherente eigenschap zijn van het virus is op dit moment nog niet duidelijk. Verwacht wordt dat experimenten met een endotheel-geadapteerde HCMV stam hierover meer duidelijkheid kunnen verschaffen.

Vanwege de strategilsche ligging van endotheelcellen, tussen het circulatie systeem en het omliggende weefsel ${ }_{\text {" }}$ is het voor de hand liggend om aan te nemen dat endotheelcellen zich beschermen tegen de infectie met HCMV. Echter doordat de infectie van enkele endotheelcellen toch leidt tot duidelijk meetbare effecten zoals verhoogde stollingsactiviteit, verhoogde membraanverstoring, expressie van achesiemoleculen en de afgifte van cytokines, kan verondersteld worden dat het cytomegalovirus een rol kan spelen bij verschillende vasculaire ziektes. Het is moeilijk om aan te tonen of cytomegalovirus infectie de oorzaak zijn van vasculaire pathologie of dat HCMV infectie van endotheelcellen eerder het gevolg is van immunologische processen die bij deze vasculaire afwijkingen een rol spelen. Verdere in vitro en in vivo studies zullen hierin meer duidelijkheid moeten verschaffen. 


\section{LIST OF PUBLICATIONS}

van Geelen, A.G.M., Slobbe-van Drunen, M.E.P., Muller, A.D., Bruggeman, C.A. and van Dam-Mieras, M.C.E. (1995) Membrane related effects in endothelial cells induced by human cytomegalovirus. Archives of Virology 140:1601-1612

Vossen, R.C.R.M., Derhaag, J.G., Slobbe-van Drunen, M.E.P., Duijvenstijn, A.M., van Dam-Mieras, M.C.E. and Bruggeman, C.A. (1996) A dual role for endothelial cells in cytomegalovirus infection? A study of cytomegalovirus infection in a series of rat endothelial cell lines. Virus Res. 46: 65-74

Slobbe-van Drunen, M.E.P ", Vossen, R.C.R.M." Couwenberg, F.M.D., Hulsbosch, M.M., Heemskerk, J.W.M., van Dam-Mieras, M.C.E. and Bruggeman, C.A. (1997) Activation of protein kinase $C$ enhances the infection of endothelial cells by human cytomegalovirus. Virus Res. 48: 207-213

Vossen, R.C.R.M., Persoons, M.C.J., Slobbe-van Drunen, M.E.P., Bruggeman, C.A. and van Dam-Mieras, M.C.E. (1997) Intracellular thiol redox status affects cytomegalovirus infection of vascular cells. Virus Res. 48: 173-183

Slobbe-van Drunen, M.E.P., Hendrickx, A.T.M., Vossen, R.C.R.M., Speel, E.J.M., van Dam-Mieras, M.C.E. and Bruggeman, C.A. (1998) Nuclear import as a barrier to infection of human umbilical vein endothelial cells by human cytomegalovirus strain AD169. Virus Res. In press

Bodaghi, B., Slobbe-van Drunen, M.E.P., Topilko, A., Perret, E., Vossen " R.C.R.M., van Dam-Mieras, M.C.E., Zipeto, D., Virelizier, J.L., LeHoang, P.* Bruggeman, C.A. and Michelson, S. Human cytomegalovirus (HCMV) enters retinal pigmant epithelial and endothelial cells by endocytosis. Submitted for publication 


\section{CURRICULUM VITAE}

Marlea Slobbe-van Drunen werd geboren op 5 juli 1964 te Vught. Na het behalen van het Atheneum B diploma op het Sint-Janslyceum te 's-Hertogenbosch begon zij in 1984 met de studie Biologie aan de Katholieke Universiteit Nijmegen. In december 1989 werd het doctoraal diploma Biologie behaald met als afstudeerrichting Biochemie. In de periode van januari 1990 tot oktober 1993 verrichte zij onderzoek bij in eerste instantie de vakgroep Biochemie van de Katholieke Universiteit Nijmegen en in tweede instantie bij de vakgroep Moleculaire Celbiologie \& Genetica van de Universiteit Maastricht.

Met uitzondering van twee onderbrekingen door zwangerschap (augustus 1994maart 1995 en maart 1997-oktober 1997) is van november 1994 tot juli 1998 promotieonderzoek verricht als onderzoeksassistent verbonden aan de vakgroep Medische Microbiologie van de Universiteit van Maastricht onder begeleiding van Prof. Dr. C.A. Bruggeman en Prof. Dr. M.C.E. van Dam-Mieras. Dit resulteerde in het proefschrift getiteld "The interplay between human cytomegalovirus and endothelial cells". 


\section{DANKWOORD}

Nu ik dit hier zo schrijf is veruit het meeste werk al verricht wat noodzakelijk is voor een promotie. Tijdens het tot stand komen van dit proefschrift hebben echter vele mensen een bijdrage geleverd zowel op wetenschappelijk als sociaal gebied. Hierbij wil ik dan ook iedereen bedanken die op enigerlei wijze bijgedragen heeft aan mijn promotieonderzoek en de creatie van mijn proefschrift.

Enkele personen wil ik echter met naam benoemen: Allereerst Cathrien Bruggeman, die mij in een voor mij zeer moeilijke periode heeft opgenomen in haar vakgroep en mij de mogelijkheid heeft gegeven om mijn wetenschappelijke carrière voort te zetten en bij Medische Microbiologie te promoveren. Cathrien, bedankt voor het in mij gestelde vertrouwen en voor de wetenschappelijke begeleiding en ondersteuning die je me hebt gegeven. Als tweede promotor wil ik jou, Rietje van Dam-Mieras, bedanken voor het enthousiasme wat je altijd toonde voor het onderzoek tijdens onze werkbesprekingen en de begeleiding die je me gegeven hebt. Reneé Vossen, mijn co-promotor, onze soms hevige maar zeer leuke discussies waarbij vaak de hele gang kon mee genieten en de prettige manier waarop onze samenwerking verliep waren in mijn ogen uniek. Zonder jouw steun, met name wat betreft de celkweek, zou dit boekje nu zeker niet klaar zijn. Voor de mentale ondersteuning die ik tijdens het schrijven van mijn proefschrift heb ontvangen wil ik met name Gert, Joanne en Marjorie bedanken. Verder wil ik alle medewerkers van de afdeling Medische Microbiologie en met name de mensen van de Virologie bedanken voor al wat ze gedaan hebben. Puck Muller, jouw laboratorium vaardigheden op het gebied van stolling hebben geleid tot het eerste artikel van dit proefschrift, waarvoor ik je hartelijk dank. Voor de vakkundige bijdrage op het gebied van signaaltransductie wil ik Johan van Heemskerk bedanken. Mijn stagiaires Franka Couwenberg en Alexandra Hendrickx wil ik bedanken voor hun enthousiasme, inzet en gezelligheid, die ze tijdens hun aanwezigheid hebben gebracht en de afdeling verloskunde van ziekenhuis De Wever in Heerlen voor thet verzamelen van de navelstrengen waaruit de endotheelcellen zijn geïsoleerd die naast het virus de basis vormen van dit proefschrift.

Natuurlijk wil ik mijn familie, vrienden en bekenden niet vergeten die ieder op hun eigen manier een bijdrage hebben geleverd. Met name mijn broer Jean-Pierre, die mij zeer geholpen heeft bij het maken van een aantal tekeningen ${ }_{\text {en }}$ de paranimfen Rianne en Alexandra: bedankt!!! Een bijzonder plaats nemen jullie, Lars en Jasper, in: jullie vrolijke gezichtjes en ondeugende oogjes spreken woor zichzelf en hebben voor de broodnodige afleiding gezorgd. Rob, met woorden is niet te beschrijven wal je voor mij betekent, maar een ding weet ik zeker: zonder jouw steun en geduld zou dit proefschrift niet tot stand zijn gekomen. 
